\title{
Ionic Liquid and Supercritical Fluid Hyphenated Techniques for Dissolution and Separation of Lanthanides, Actinides, and Fission Products
}

Integrated University Programs

Dr. Chien Wai

University of Idaho

In collaboration with:

Idaho National Laboratory

Jack Law, Technical POC

James Bresee, Federal POC 
Ionic Liquid and Supercritical Fluid Hyphenated Techniques

For Dissolution and Separation of Lanthanides and Actinides

DOE-NEUP Project (TO 00058)

Final Technical Report

Principal Investigator: Chien M. Wai

Department of Chemistry, University of Idaho, Moscow, Idaho 83844

Date: December 1, 2012 
Table of Contents

Project Summary $\quad 3$

Publications Derived from the Project $\quad 5$

$\begin{array}{lr}\text { Chapter I. Introduction } & 6\end{array}$

Chapter II. Uranium Dioxide in Ionic Liquid with a TP-HNO ${ }_{3}$ Complex Dissolution and Coordination Environment 9

1. Dissolution of $\mathrm{UO}_{2}$ in Ionic Liquid with $\mathrm{TBP}\left(\mathrm{HNO}_{3}\right)_{1.8}\left(\mathrm{H}_{2} \mathrm{O}\right)_{0.6}$

2. Raman Spectra of Dissolved Uranyl Species in IL 13

3. Transferring Uranium from IL Phase to sc- $\mathrm{CO}_{2}$

Chapter III. Kinetic Study on Dissolution of Uranium Dioxide and $\begin{array}{ll}\text { Neodymium Sesquioxide in Ionic Liquid } & 19\end{array}$

1. Rate of Dissolution of $\mathrm{UO}_{2}$ and $\mathrm{Nd}_{2} \mathrm{O}_{3}$ in RTIL 19

2. Temperature Effect on Dissolution of $\mathrm{UO}_{2}$ and $\mathrm{Nd}_{2} \mathrm{O}_{3}$

3. Viscosity Effect on Dissolution of $\mathrm{UO}_{2}$ in $\mathrm{IL}$ with $\mathrm{TBP}\left(\mathrm{HNO}_{3}\right)_{1.8}\left(\mathrm{H}_{2} \mathrm{O}\right)_{0.6}$

Chapter IV. Separation of $\mathrm{UO}_{2}\left(\mathrm{NO}_{3}\right)_{2}(\mathrm{TBP})_{2}$ and $\mathrm{Nd}\left(\mathrm{NO}_{3}\right)_{3}(\mathrm{TBP})_{3}$ in Ionic Liquid Using Diglycolamide and Supercritical $\mathrm{CO}_{2}$ Extraction 30

1. Complexation of Uranyl with Diglycolamide TBDGA in Ionic Liquid 31

2. Complexation of Neodymium(III) with TBDGA in Ionic Liquid 35

3. Solubility and Distribution Ratio of $\mathrm{UO}_{2}\left(\mathrm{NO}_{3}\right)_{2}(\mathrm{TBP})_{2}$ and $\mathrm{Nd}\left(\mathrm{NO}_{3}\right)_{3}(\mathrm{TBP})_{3}$ in Supercritical $\mathrm{CO}_{2}$ Phase $\quad 38$

4. Supercritical Fluid Extraction for Separation of Uranium and Neodymium 41

Chapter V. Other Related Studies $\quad 45$

1. Total Reflection-Fourier Transform Infrared Study of Uranyl Nitrate Species in Ionic Liquid 45

2. The Partitioning of Americium and the Lanthanides Using Tetrabutyldiglycolamide (TBDGA) in Octanol and in Ionic Liquid 47

3. Recycling Ionic Liquid for Repeated Use 50

$\begin{array}{ll}\text { References } & 52\end{array}$

$\begin{array}{lr}\text { Appendix } & \text { 54-78 }\end{array}$ 


\section{Project Summary}

The purpose of this project is to evaluate dissolution and coordination environments of uranium and lanthanides in ionic liquid (IL) and to develop methods for their separation using ionic liquid and supercritical fluid coupled extraction techniques. Both ionic liquids and supercritical fluid carbon dioxide $\left(\mathrm{sc}-\mathrm{CO}_{2}\right)$ are considered green solvents for treatment of nuclear wastes. An ionic liquid-supercritical $\mathrm{CO}_{2}$ hyphenated dissolution, extraction and separation process may provide an environmentally sustainable method for nuclear waste management.

Direct dissolution of uranium dioxide in a hydrophobic ionic liquid, 1-butyl-3methylimidazolium bis(trifluoromethylsulfonyl)imide $\left([\mathrm{Bmim}]\left[\mathrm{T}_{2} \mathrm{~N}\right]\right)$, with $\operatorname{TBP}\left(\mathrm{HNO}_{3}\right)_{1.8}\left(\mathrm{H}_{2} \mathrm{O}\right)_{0.6}$ and subsequent extraction of the dissolved uranyl species into sc- $\mathrm{CO}_{2}$ have been demonstrated by this project. The dissolution rate of uranium dioxide $\left(\mathrm{UO}_{2}\right)$ in the IL follows pseudo-first order kinetics. Raman spectroscopy is used to characterize the coordination environment of the uranyl species in the IL. The uranyl species extracted into sc- $\mathrm{CO}_{2}$ phase is identified to be $\mathrm{UO}_{2}\left(\mathrm{NO}_{3}\right)_{2}(\mathrm{TBP})_{2}$. The ionic liquid used in the dissolution/extraction process can be recycled for repeated use.

The rates of dissolution of $\mathrm{UO}_{2}$ and neodymium sesquioxide $\left(\mathrm{Nd}_{2} \mathrm{O}_{3}\right)$ in $[\mathrm{Bmim}]\left[\mathrm{Tf}_{2} \mathrm{~N}\right]$ with $\operatorname{TBP}\left(\mathrm{HNO}_{3}\right)_{1.8}\left(\mathrm{H}_{2} \mathrm{O}\right)_{0.6}$ increase with temperature. The rate of $\mathrm{Nd}_{2} \mathrm{O}_{3}$ dissolution is faster than that of $\mathrm{UO}_{2}$ probably because dissolution of the latter requires oxidation of $\mathrm{U}(\mathrm{IV})$ to $\mathrm{U}(\mathrm{VI})$. The activation energy $\left(E_{a}\right)$, enthalpy $\left(\Delta H^{\ddagger}\right)$, and entropy $\left(\Delta S^{\ddagger}\right)$ of activation of the dissolution processes have been calculated. The dissolution rate of $\mathrm{UO}_{2}$ in the IL with $\operatorname{TBP}\left(\mathrm{HNO}_{3}\right)_{1.8}\left(\mathrm{H}_{2} \mathrm{O}\right)_{0.6}$ is about a factor of 2 faster than that reported for the dissolution or $\mathrm{UO}_{2}$ in $8 \mathrm{M}$ nitric acid.

Supercritical $\mathrm{CO}_{2}$ extraction and separation of $\mathrm{UO}_{2}\left(\mathrm{NO}_{3}\right)_{2}(\mathrm{TBP})_{2}$ and $\mathrm{Nd}\left(\mathrm{NO}_{3}\right)_{3}(\mathrm{TBP})_{3}$ in IL can be achieved by means of ligand exchange with diglycolamide. Tetrabutyldiglycolamide (TBDGA) in [Bmim] $\left[\mathrm{Tf}_{2} \mathrm{~N}\right]$ is capable of replacing TBP coordinated with the metal ions forming TBDGA complexes which are not soluble in sc-CO $\mathrm{CO}_{2}$. The TBDGA complex with $\mathrm{Nd}\left(\mathrm{NO}_{3}\right)_{3}$ is more stable than with $\mathrm{UO}_{2}\left(\mathrm{NO}_{3}\right)_{2}$. In the presence of a proper amount of TBDGA in $[\mathrm{Bmim}]\left[\mathrm{Tf}_{2} \mathrm{~N}\right]$ with $\mathrm{UO}_{2}\left(\mathrm{NO}_{3}\right)_{2}(\mathrm{TBP})_{2}$ and $\mathrm{Nd}\left(\mathrm{NO}_{3}\right)_{3}(\mathrm{TBP})_{3}$, uranium could be extracted by sc$\mathrm{CO}_{2}$ without co-extraction of neodymium. The fraction of uranium extracted by sc- $\mathrm{CO}_{2}$ depends on the relative amount of the two metals and the amount of TBDGA added to the IL phase. 
This study also demonstrates that Fourier Transform Infrared (FTIR) spectroscopy is a useful tool for characterizing uranyl species in ionic liquids. The asymmetric vibrational mode of uranyl $(\mathrm{O}=\mathrm{U}=\mathrm{O})^{2+}$ observed in FTIR varies with different nitrate coordination. The IR bands of $\mathrm{UO}_{2}\left(\mathrm{NO}_{3}\right)^{+}, \mathrm{UO}_{2}\left(\mathrm{NO}_{3}\right)_{2}$ and $\mathrm{UO}_{2}\left(\mathrm{NO}_{3}\right)_{3}{ }^{-}$in ionic liquids have been identified and used as an example to illustrate the distribution of these species in IL containing uranyl and different concentrations of nitrate ions. The partitioning of americium $\left(\mathrm{Am}^{3+}\right)$ and trivalent lanthanides $\left(\mathrm{Ln}^{3+}\right)$ between nitric acid and ionic liquid solution using TBDGA as a ligand has also been investigated. The separation factor of Eu/Am is not large enough for practical application but group separation of lanthanides may be achieved utilizing this extraction system. Finally, a simple method for recycling ionic liquids for repeated use is described at the end of the report. In summary, this project has produced some basic information for understanding direct dissolution of uranium dioxide and lanthanide sesquioxide in ionic liquid and their subsequent extraction and separation by supercritical fluid $\mathrm{CO}_{2}$. This knowledge is essential for developing ionic liquid and supercritical fluid-based techniques for potential nuclear waste management applications. 


\section{Publications Derived from the Project}

D.L. Quach, C.M. Wai, S.P. Pasilis, "Characterization of Uranyl(VI) Nitrate Complexes in a Room Temperature Ionic Liquid Using Attenuated Total Reflection-Fourier Transform Infrared Spectrometry”, Inorganic Chemistry, 2010, 49, 8568-8572.

C.M. Wai, Y.J. Liao, Weisheng Liao, Guoxin Tian, R.S. Addleman, Donna Quach, S.P. Pasilis, "Uranium Dioxide in Ionic Liquid with a Tri-n-butylphosphate- $\mathrm{HNO}_{3}$ Complex - Dissolution Kinetics and Coordination Environment", Dalton Transactions 2011, 40, 5039-5045.

M.E. Mincher, D.L. Quach, Y.J. Liao, B.J. Mincher, C.M. Wai, "The Partitioning of Americium and the Lanthanides Using Tetrabutyldiglycolamide (TBDGA) in Octanol and in Ionic Liquid Solution", Solvent Extraction and Ion Exchange, 2012, 30, 735-747.

Y.J. Liao, C.M. Wai, "Kinetic Study on Dissolution of Uranium Dioxide and Neodymium Sesquioxide in Ionic Liquid with a Tri-n-butylphosphate-Nitric Acid Complex", Industrial and Engineering Chemistry Research, Submitted in September, 2012.

C.M. Wai, "Green Separation Techniques for Nuclear Waste Management" in Nuclear Energy and the Environment, ACS Symposium Series 1046, Ed. B.J. Mincher and C.M. Wai, 2010, American Chemical Society, Washington, DC, Chapter 5, p 53-64.

\section{Students Supported by the Project}

Donna L. Quach, chemistry graduate student, Ph.D. candidate, expected to finish her Ph.D. degree at the University of Idaho in 2013.

Janet Yu-jung Liao, chemistry graduate student, completed her Ph.D. degree at the University of Idaho in November 2012.

Mary E. Mincher, chemistry undergraduate student, Boise State University, expected to complete B.S. degree in May 2013.

\section{Student Dissertation Derived from the Project}

Y.J. Liao, "Actinide and Lanthanide Species in Ionic Liquid and in Supercritical $\mathrm{CO}_{2}$ Dissolution, Coordination, and Separation", Ph.D. Dissertation, Department of Chemistry, University of Idaho, Moscow, Idaho 83844, November, 2012. 


\section{Chapter I. Introduction}

Supercritical fluid carbon dioxide $\left(\mathrm{sc}-\mathrm{CO}_{2}\right)$ and ionic liquids (ILs) are considered green solvents for chemical reactions and separations. ${ }^{1}$ Carbon dioxide is widely used in supercritical fluid studies because of its moderate critical constants $\left(\mathrm{T}_{\mathrm{c}}=31{ }^{\circ} \mathrm{C}\right.$ and $\left.\mathrm{P}_{\mathrm{c}}=73 \mathrm{~atm}\right)$, nonflammable nature, chemical inertness, and low cost. Supercritical $\mathrm{CO}_{2}$ has mechanical properties like a gas and yet has solvation strength like a liquid. Therefore, $\mathrm{sc}-\mathrm{CO}_{2}$ is capable of penetrating into small pores of solids and dissolving organic compounds in the solid matrix. After sc- $\mathrm{CO}_{2}$ extraction, the fluid phase can be converted to $\mathrm{CO}_{2}$ gas by reduction of pressure causing rapid precipitation of the extracted solutes. One application of the sc- $\mathrm{CO}_{2}$ extraction technology is in the field of nuclear waste management because the technology does not require conventional liquid solvents. Since carbon dioxide is a linear triatomic molecule with no dipole moment, sc- $\mathrm{CO}_{2}$ is a good solvent for non-polar compounds but is ineffective for dissolving highly polar compounds or metal ions. The extraction strategy for metal species is to use a $\mathrm{CO}_{2}$ soluble chelating agent or ligand which would bind to the target metal ions to form $\mathrm{CO}_{2}$-soluble metal chelates (or metal complexes) which could be removed from the system by $\mathrm{sc}-\mathrm{CO}_{2}$. A number of $\mathrm{CO}_{2}$-soluble chelating agents and ligands including fluorinated $\beta$-diketones and phosphorus-containing ligands such as tri-n-butylphosphate (TBP) have been studied for supercritical fluid extraction of lanthanides and actinides. The dissolution of uranium oxides in sc- $\mathrm{CO}_{2}$ with a $\mathrm{CO}_{2}$-soluble TBP-nitric acid complex of the formula $\mathrm{TBP}\left(\mathrm{HNO}_{3}\right)_{1.8}\left(\mathrm{H}_{2} \mathrm{O}\right)_{0.6}$ is of particular interest to nuclear waste treatment. ${ }^{2}$ This reagent, basically a Lewis acid-Lewis base complex, is easily prepared in the lab by shaking TBP with an equal volume of the concentrated nitric acid $(15.5 \mathrm{M})$. In the mixing process, $\mathrm{HNO}_{3}$ and a small amount of $\mathrm{H}_{2} \mathrm{O}$ molecules will migrate to the organic phase via hydrogen bonding with the $\mathrm{P}=\mathrm{O}$ group of TBP leaving the majority of the water behind in the aqueous phase. Because TBP is highly soluble in sc- $\mathrm{CO}_{2}$, it serves as a carrier for dissolution and dispersion of $\mathrm{HNO}_{3}$ in the $\mathrm{sc}-\mathrm{CO}_{2}$ phase. Dissolution of uranium oxides in sc- $\mathrm{CO}_{2}$ using TBP-nitric acid complexes to form $\mathrm{UO}_{2}\left(\mathrm{NO}_{3}\right)_{2}(\mathrm{TBP})_{2}$ has been reported. The solubility of $\mathrm{UO}_{2}\left(\mathrm{NO}_{3}\right)_{2}(\mathrm{TBP})_{2}$ in $\mathrm{sc}-\mathrm{CO}_{2}$ is very high, reaching 0.45 moles per liter at $40{ }^{\circ} \mathrm{C}$ and $200 \mathrm{~atm}$, which is comparable to the concentration of $\mathrm{UO}_{2}\left(\mathrm{NO}_{3}\right)_{2}(\mathrm{TBP})_{2}$ used in the traditional PUREX process. ${ }^{3}$

Ionic liquids (ILs) are low temperature molten salts composed of an organic cation and an anion of various forms. Ionic liquids have unique properties including non-flammable nature, 
near zero vapor pressure and high solubilities for a variety of compounds. These properties make ILs attractive for replacing volatile organic solvents traditionally used in liquid-liquid extraction processes. One type of room temperature ionic liquids (RTIL) based on 1-alkyl-3methylimidazolium cation [Bmin] with a fluorinated anion is immiscible with water (hydrophoblic). The RTIL composed of [Bmin] with bis(trifluoromethylsulfonyl)imide anion $\left[\mathrm{Tf}_{2} \mathrm{~N}\right]$ is of particular interest for extraction of metal ions due to its water stability, relative low viscosity, high conductivity, good electrochemical and thermal stability. ${ }^{4}$ The chemical structure of $[\mathrm{Bmin}]\left[\mathrm{Tf}_{2} \mathrm{~N}\right]$ is shown in Figure I-1. Extractions of trivalent lanthanides and uranyl ions from nitric acid into IL with $\beta$-diketones, TBP and CMPO are known in the literature. ${ }^{4,5}$ After extraction, recovery of the dissolved metal complexes could be accomplished by back-extraction with an organic solvent or using electrochemical methods. Both ILs and sc- $\mathrm{CO}_{2}$ show good radiation stability, an attractive property for their utilization as media for processing radioactive materials.

It was reported recently that a hyphenated ionic liquid-supercritical fluid extraction system can effectively transfer trivalent lanthanide ions and uranyl ions from nitric acid solutions to the $[\mathrm{bmin}]\left[\mathrm{Tf}_{2} \mathrm{~N}\right]$ phase with $\beta$-diketone or TBP and finally transfer to the $\mathrm{sc}-\mathrm{CO}_{2}$ phase as illustrated by the two-loop three phases extraction system shown in Figure I-1. ${ }^{6}$ The IL-sc-CO coupled extraction is based on the fact that sc- $\mathrm{CO}_{2}$ dissolves effectively in IL and the solubility of IL in sc- $\mathrm{CO}_{2}$ is negligible. The advantages of this new IL-sc- $\mathrm{CO}_{2}$ coupled extraction technique include: (1) radionuclides from the aqueous wastes can be transferred to and concentrated in an ionic liquid under ambient temperature and pressure, (2) no loss of the IL occurs in the sc- $\mathrm{CO}_{2}$ back-extraction process and no organic solvent is introduced into the ionic liquid phase, and (3) after the back-extraction step, the IL may be reused and the $\mathrm{CO}_{2}$ also recycled after precipitation of the solutes by pressure reduction.

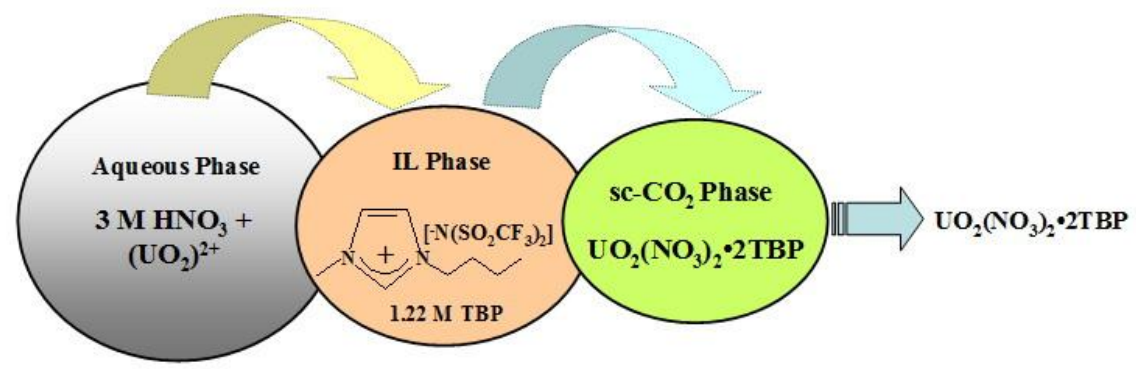

Figure I-1. Ionic liquid and sc- $\mathrm{CO}_{2}$ coupled extraction of uranyl from nitric acid solution. 
For treating $\mathrm{UO}_{2}$ containing wastes, the three-phases extraction system shown in Figure I-1 requires dissolution of solid $\mathrm{UO}_{2}$ in nitric acid first followed by extraction of uranyl-nitrate species from the acid solution into the ionic liquid phase containing TBP. Aqueous acid waste is still produced from such a process. If $\mathrm{UO}_{2}$ and $\mathrm{Ln}_{2} \mathrm{O}_{3}$ (lanthanide oxides) can be dissolved directly in an ionic liquid with a TBP-nitric acid complex (Figure I-2), then the acid dissolution step and associated aqueous acid waste may be avoided. One objective of this project is to investigate the dissolution of $\mathrm{UO}_{2}$ and $\mathrm{Ln}_{2} \mathrm{O}_{3}$ directly in $[\mathrm{Bmim}]\left[\mathrm{Tf}_{2} \mathrm{~N}\right]$ using $\operatorname{TBP}\left(\mathrm{HNO}_{3}\right)_{1.8}\left(\mathrm{H}_{2} \mathrm{O}\right)_{0.6}$ as a complexing agent. Knowledge on the kinetics of the dissolution process and the coordination environment of the dissolved metal species in the ionic liquid phase is essential for understanding the dissolution process. Methods of Separating dissolved uranium and lanthanides from the ionic liquid phase into supercritical fluid $\mathrm{CO}_{2}$ are also needed for recovering uranium using the $\mathrm{IL}-\mathrm{sc}-\mathrm{CO}_{2}$ coupled dissolution/separation process. Experimental studies on dissolution, solvation, complexation and distribution of lanthanides and actinides in ionic liquid and in supercritical fluid should provide basic knowledge for developing new extraction/separation techniques which could significantly reduce liquid waste generation in nuclear waste management. The knowledge may also be useful for better understanding the solvation and complexation behaviors of lanthanides and actinides in molten salt systems and in conventional solvent extraction processes.

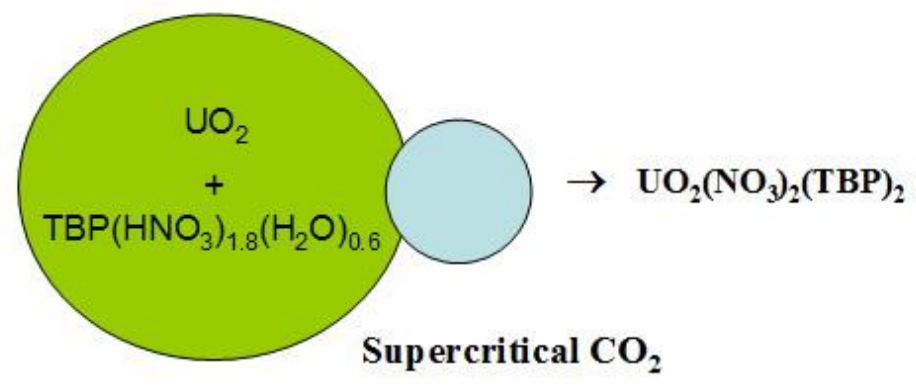

Ionic Liquid

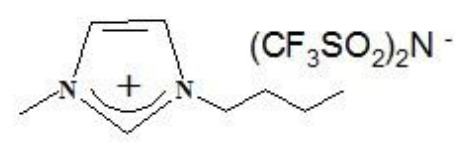

Figure I-2. Direct dissolution of $\mathrm{UO}_{2}$ in ionic liquid followed by supercritical $\mathrm{CO}_{2}$ extraction. 
Chapter II. Uranium Dioxide in Ionic Liquid with a $\mathrm{TBP}_{-H N O} \mathrm{Complex}_{3}$ Dissolution and Coordination Environment

Direct dissolution of $\mathrm{UO}_{2}$ in ionic liquids using concentrated nitric acid has been reported by several researchers. ${ }^{7}$ The uranyl species dissolved in [BMIM] $\left[\mathrm{Tf}_{2} \mathrm{~N}\right]$ with nitric acid are not extractable by sc- $\mathrm{CO}_{2}$. In this project, a method of dissolving $\mathrm{UO}_{2}$ directly in $[\mathrm{BMIM}]\left[\mathrm{Tf}{ }_{2} \mathrm{~N}\right]$ at room temperature using $\operatorname{TBP}\left(\mathrm{HNO}_{3}\right)_{1.8}\left(\mathrm{H}_{2} \mathrm{O}\right)_{0.6}$ as a complexing agent is developed. The dissolved uranyl species is extractable by $\mathrm{sc}-\mathrm{CO}_{2}$. We have also used Raman spectroscopy to evaluate coordination environment of uranium species dissolved in the IL phase. Uranyl $(\mathrm{O}=\mathrm{U}=\mathrm{O})^{2+}$ is a linear triatomic ion. The symmetric vibrational mode of uranyl ion $(\mathrm{O}=\mathrm{U}=\mathrm{O})^{2+}$ is Raman active and the asymmetric vibrational mode is IR (infrared) active. Coordination of uranyl with different ligands would shift its vibrational modes. Thus, Raman or IR spectroscopy provides a good tool for studying the coordination environment of uranyl ions dissolved in the IL system. Using vibrational spectroscopy (FTIR) to characterize uranyl nitrate complexes in ionic liquid is given in one of the publications derived from this study. ${ }^{8}$ This section describes our approach of utilizing Raman spectroscopy to evaluate coordination environment of uranylnitrate-TBP species in ionic liquid and in supercritical $\mathrm{CO}_{2}$. An interesting observation from our Raman study is that the dissolved uranyl species is coordinated with two molecules of TBP indicating that it probably exists as a mixture of the form $\mathrm{UO}_{2}(\mathrm{TBP})_{2}\left(\mathrm{NO}_{3}\right)_{\mathrm{x}}$ in the IL system where $\mathrm{x}$ may be 1,2 , and 3. The rate of dissolution of $\mathrm{UO}_{2}$ in the $\mathrm{IL}$ and transfer of the dissolved uranyl species to sc- $\mathrm{CO}_{2}$ are also described. After supercritical fluid extraction, the IL can be reused for $\mathrm{UO}_{2}$ dissolution. This $\mathrm{IL} / \mathrm{sc}-\mathrm{CO}_{2}$ hyphenated process, which enables continuous dissolution of uranium in the IL with subsequent transfer to $\mathrm{sc}-\mathrm{CO}_{2}$ without formation of an aqueous phase, may provide a new green technique for recycling uranium from solid wastes.

\section{II-1. Dissolution of $\mathrm{UO}_{2}$ in Ionic Liquid with $\mathrm{TBP}\left(\mathrm{HNO}_{3}\right)_{1.8}\left(\mathrm{H}_{2} \mathrm{O}\right)_{0.6}$}

The $\operatorname{TBP}\left(\mathrm{HNO}_{3}\right)_{1.8}\left(\mathrm{H}_{2} \mathrm{O}\right)_{0.6}$ complex is miscible with [BMIM] $\left[\mathrm{Tf}_{2} \mathrm{~N}\right]$, forming one homogeneous liquid phase at the volume ratio (1:5). With $26.2 \mathrm{mg}$ of solid $\mathrm{UO}_{2}$ added to 3.6 $\mathrm{mL}$ of the $[\mathrm{BMIM}]\left[\mathrm{Tf}_{2} \mathrm{~N}\right]$ solution, the ratios of $[\mathrm{TBP}] /[\mathrm{U}],\left[\mathrm{HNO}_{3}\right] /[\mathrm{U}]$, and $\left[\mathrm{H}_{2} \mathrm{O}\right] /[\mathrm{U}]$ in the $\mathrm{IL}$ phase were about 16,28 , and 11 , respectively. With stirring, the black $\mathrm{UO}_{2}$ powder gradually dissolved in the $[\mathrm{BMIM}]\left[\mathrm{Tf}_{2} \mathrm{~N}\right]$ solution, turning the color of the IL phase to bright yellow. The dissolution process was monitored by acquiring UV/Vis spectra of the IL phase at different times 
as shown in Figure II-1a. About $81 \%$ of the $\mathrm{UO}_{2}(\mathrm{~s})$ dissolved in the IL phase at room temperature in the first hour and $8 \%$ more dissolved in the second hour. The absorbances of the peaks at $372,388,437$, and $452 \mathrm{~nm}$ with respect to dissolution time are shown in Figure II-1b. The intensities of the peaks at 437, and $452 \mathrm{~nm}$ increased rapidly with time in the first $60 \mathrm{~min}$ and reached a plateau in about $120 \mathrm{~min}$. However, the peaks at 372 and $388 \mathrm{~nm}$ reached a maximum absorption at $66 \mathrm{~min}$ and then decreased after that. This observation was similar to a previous report in which the dissolution of $\mathrm{UO}_{2}$ in $[\mathrm{BMIM}]\left[\mathrm{Tf}_{2} \mathrm{~N}\right]$ containing aqueous nitric acid was studied at room temperature by $\mathrm{UV} / \mathrm{V}$ is spectroscopy at a $\left[\mathrm{HNO}_{3}\right] /[\mathrm{U}]$ ratio of 16 and $\left[\mathrm{H}_{2} \mathrm{O}\right] /[\mathrm{U}]$ ratio of $33 .^{7}$ The absorption peaks at wavelengths above $400 \mathrm{~nm}$ were reported to increase from 0 to $66 \mathrm{~min}$ and then remain practically constant for up to $900 \mathrm{~min}$. But, the peaks at wavelengths below $400 \mathrm{~nm}$ were found to increase in the first $66 \mathrm{~min}$, followed by a decrease in absorbance after that. The cause of the fluctuations in absorption for the peaks below $400 \mathrm{~nm}$ was attributed to the formation of transient absorbing species during the dissolution process which involves oxidation of $\mathrm{U}(\mathrm{IV})$ to $\mathrm{U}(\mathrm{VI})$ via $\mathrm{NO}_{3}{ }^{-} / \mathrm{NO}_{2}{ }^{-}$reduction and changes in background absorption. $^{7}$
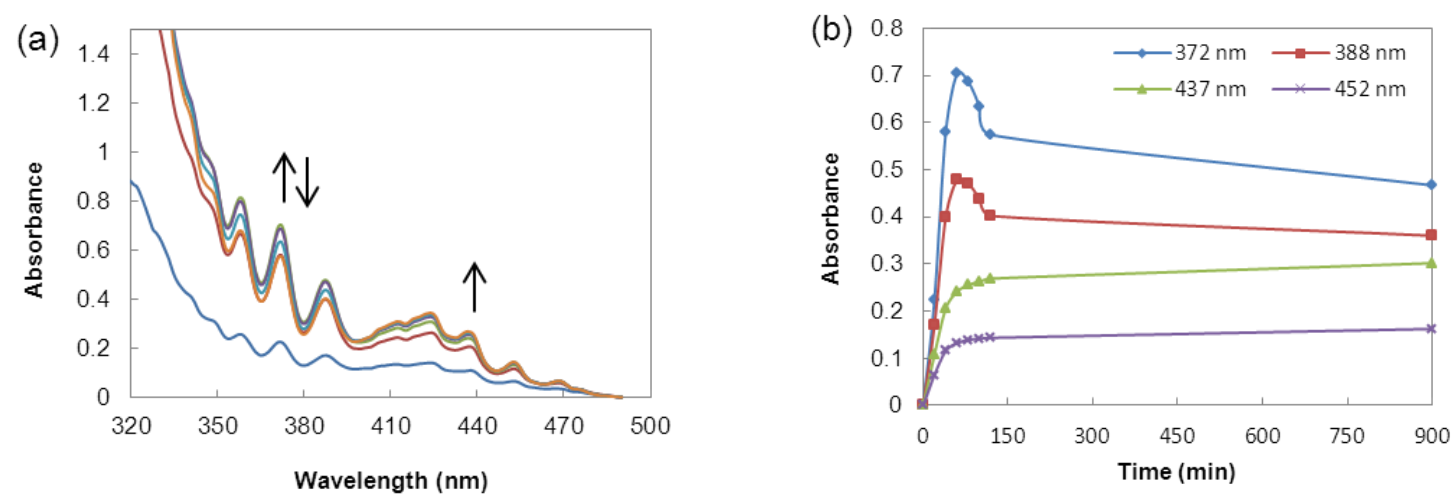

Figure II-1. Rate of dissolution of $\mathrm{UO}_{2}(\mathrm{~s})$ in $[\mathrm{BMIM}]\left[\mathrm{Tf}_{2} \mathrm{~N}\right]$ with $\mathrm{TBP}\left(\mathrm{HNO}_{3}\right)_{1.8}\left(\mathrm{H}_{2} \mathrm{O}\right)_{0.6}$ ( $16.7 \%$ by volume) at room temperature: (a) UV/Vis spectra between 320 and $500 \mathrm{~nm}$; (b) absorbance versus dissolution time ( $\min$ ) for peaks at 372, 388, 437, and $452 \mathrm{~nm}$.

The rate of dissolution of $\mathrm{UO}_{2}$ in $[\mathrm{BMIM}]\left[\mathrm{Tf}_{2} \mathrm{~N}\right]$ with $\mathrm{TBP}\left(\mathrm{HNO}_{3}\right)_{1.8}\left(\mathrm{H}_{2} \mathrm{O}\right)_{0.6}$ at room temperature $\left(23{ }^{\circ} \mathrm{C}\right)$ depends on the stirring speed of the magnetic stirrer. Between 900 and 1200 $\mathrm{rpm}$, the dissolution rate of $\mathrm{UO}_{2}$ in this IL system reaches near a constant under our experimental conditions. Therefore, all $\mathrm{UO}_{2}$ dissolution experiments in this study were carried out at a stirring speed of $1200 \pm 10 \mathrm{rpm}$. The stirring speed was checked by a tachometer. Stirring is always 
required in conventional nitric acid dissolution of $\mathrm{UO}_{2}$ powder but the speed is usually much lower compared with our IL dissolution process due to the high viscosity of IL.

The initial rate of dissolution of $\mathrm{UO}_{2}$ in the IL (Figure II-1b) increases exponentially and resembles first order kinetics. A plot of $\ln \left[\left(\mathrm{A}_{\infty}-\mathrm{A}\right) / \mathrm{A}_{\infty}\right]$ versus time is shown in Figure II-2, where $\mathrm{A}$ is the absorbance at time $\mathrm{t}$ and $\mathrm{A}_{\infty}$ is taken as the absorbance at $900 \mathrm{~min}$. The absorption data at $437 \mathrm{~nm}$ and at $452 \mathrm{~nm}$ are used in this plot and both absorption peaks give the same result. The initial dissolution appears to follow pseudo first-order kinetics as demonstrated by the linear relationship between $\ln \left[\left(\mathrm{A}_{\infty}-\mathrm{A}\right) / \mathrm{A}_{\infty}\right]$ and $\mathrm{t}$ shown in Figure II-2. The slope of the line is about $0.028 \mathrm{~min}^{-1}$ (or $\mathrm{t}_{1 / 2}=24.7 \mathrm{~min}$ ), which may be regarded as the rate constant of the initial pseudo first-order dissolution process for $\mathrm{UO}_{2}$ in $[\mathrm{BMIM}]\left[\mathrm{Tf}_{2} \mathrm{~N}\right]$ with $\operatorname{TBP}\left(\mathrm{HNO}_{3}\right)_{1.8}\left(\mathrm{H}_{2} \mathrm{O}\right)_{0.6}$.

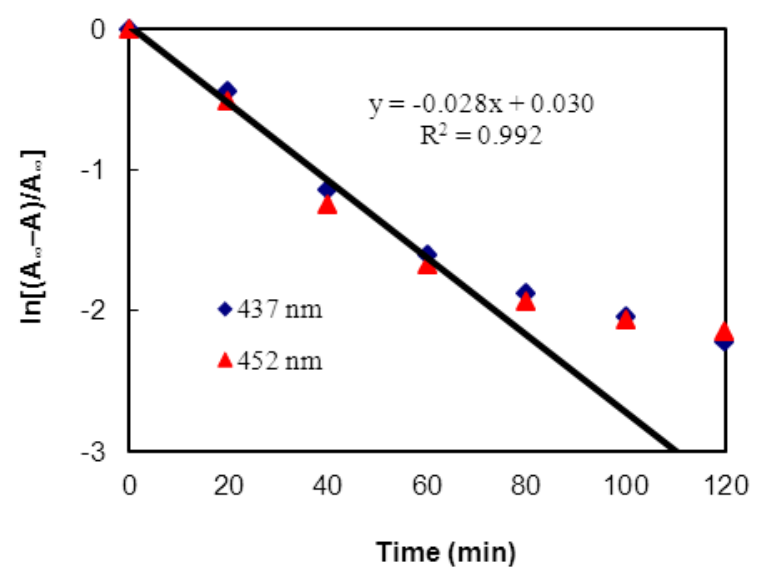

Figure II-2. Plot of $\ln \left[\left(\mathrm{A}_{\infty}-\mathrm{A}\right) / \mathrm{A}_{\infty}\right]$ versus time for the dissolution of $\mathrm{UO}_{2}$ in $[\mathrm{BMIM}]\left[\mathrm{Tf} \mathrm{f}_{2} \mathrm{~N}\right]$ containing $\mathrm{TBP}\left(\mathrm{HNO}_{3}\right)_{1.8}\left(\mathrm{H}_{2} \mathrm{O}\right)_{0.6}$

The dissolution process can be envisioned to involve a number of steps including diffusion of $\operatorname{TBP}\left(\mathrm{HNO}_{3}\right)_{1.8}\left(\mathrm{H}_{2} \mathrm{O}\right)_{0.6}$ to the $\mathrm{UO}_{2}$ surface, oxidation of $\mathrm{UO}_{2}$ to uranyl on the $\mathrm{UO}_{2}$ surface, and diffusion of uranyl species from the solid surface to the IL phase. Diffusion of the uranyl species from the $\mathrm{UO}_{2}$ surface to the IL phase is probably a main factor controlling the rate of dissolution of $\mathrm{UO}_{2}$. Deviation from the linear relationship occurs after $60 \mathrm{~min}$ indicating occurrence of other processes which would affect the steady diffusion of uranyl at higher uranium concentrations in the IL phase.

To evaluate the maximum amount of $\mathrm{UO}_{2}$ dissolution in the [BMIM] $\left[\mathrm{Tf}_{2} \mathrm{~N}\right] /$ $\mathrm{TBP}\left(\mathrm{HNO}_{3}\right)_{1.8}\left(\mathrm{H}_{2} \mathrm{O}\right)_{0.6}$ system, different amounts of $\mathrm{UO}_{2}$ were added to the $\mathrm{IL}$ phase repeatedly 
every two hours. After each addition, the IL phase was stirred for two hours and then analyzed by UV/Vis spectroscopy (Figure II-3a). The absorption peaks at 437, 452, and $468 \mathrm{~nm}$ increase linearly with increasing amounts of dissolved $\mathrm{UO}_{2}$. After addition of $234.9 \mathrm{mg}(0.24 \mathrm{M})$ of $\mathrm{UO}_{2}$, the absorbances of the peaks at wavelengths below $437 \mathrm{~nm}$ begin to fluctuate. Figure II- $3 \mathrm{~b}$ shows the absorbance for peaks at 437, 452, and $468 \mathrm{~nm}$ with respect to increasing amount of $\mathrm{UO}_{2}$ dissolved in the IL phase. Generally speaking, the absorbance increases close to a linear fashion with the amount of $\mathrm{UO}_{2}$ added to the system up to $245 \mathrm{mg}$. After addition of over 320 mg of $\mathrm{UO}_{2}(0.33 \mathrm{M})$, black slurry started to appear in the IL phase, suggesting that the system had reached its saturation point under the experimental conditions. This quantity (320 mg $\left.\mathrm{UO}_{2}\right)$ is considered as the maximum amount of $\mathrm{UO}_{2}$ soluble in $3.6 \mathrm{~mL}$ of $[\mathrm{BMIM}]\left[\mathrm{Tf}_{2} \mathrm{~N}\right]$ at room temperature $\left(23{ }^{\circ} \mathrm{C}\right)$.
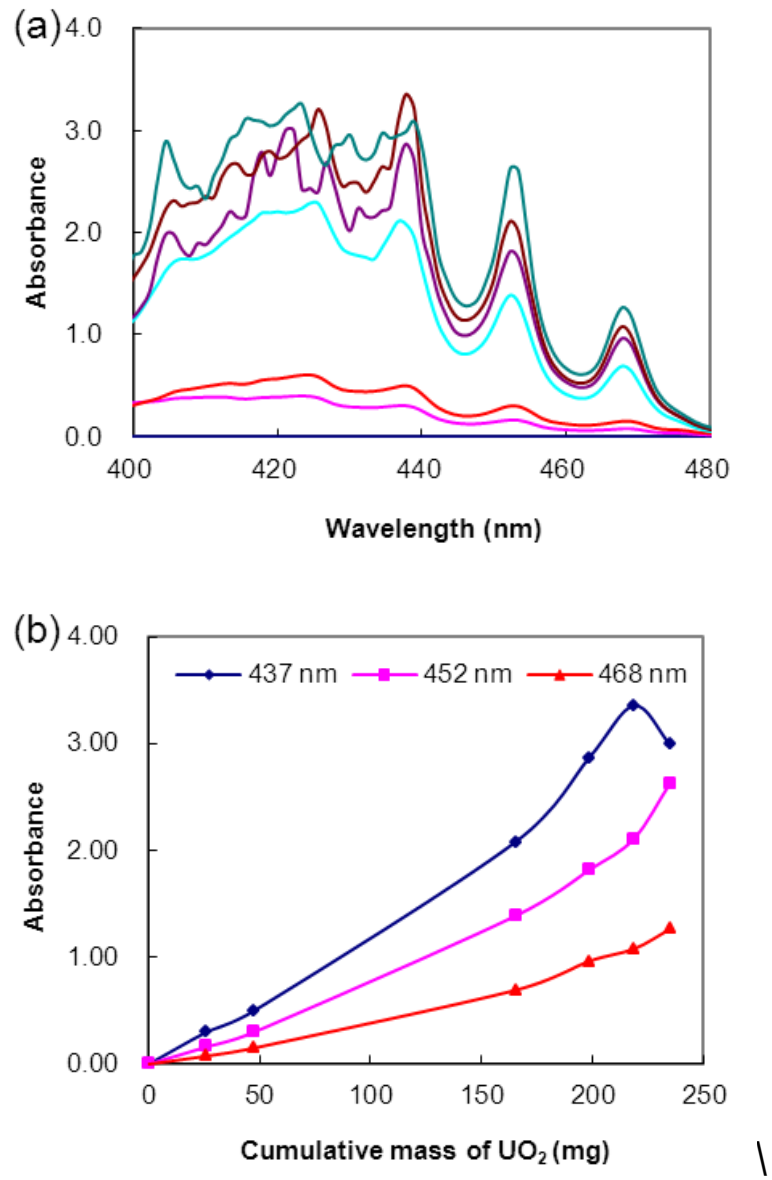

Figure II-3. Cumulative $\mathrm{UO}_{2}$ dissolution in $[\mathrm{BMIM}]\left[\mathrm{Tf}_{2} \mathrm{~N}\right]$ with $\mathrm{TBP}\left(\mathrm{HNO}_{3}\right)_{1.8}\left(\mathrm{H}_{2} \mathrm{O}\right)_{0.6}$ at room temperature: (a) UV/Vis spectra between 400 and $480 \mathrm{~nm}$; (b) absorbance versus cumulative mass plot at 437,453 , and $468 \mathrm{~nm}$. 


\section{II-2. Raman Spectra of Dissolved Uranyl Species in IL}

One interesting property of ILs is their unusual solvation character, which is reflected in their ability to dissolve many chemical materials including both ionic species and neutral compounds. Understanding the chemical environment of uranyl and other actinide species dissolved in an IL system is important for applying the technology to managing uraniumcontaining wastes. The absorption spectra of uranyl nitrate dissolved in $[\mathrm{BMIM}]\left[\mathrm{Tf}_{2} \mathrm{~N}\right]$ have been described in the literatures. ${ }^{7,9,10}$ Comparing our UV/Vis spectrum with those reported in the literature $^{7}$, the absorption spectra of uranyl species with and without TBP show a difference in the wavelength range between $390-430 \mathrm{~nm}$. We cannot determine whether the dissolved uranyl ions exist in the IL phase as individual ions or are associated with TBP. It is known that the Raman active uranyl symmetrical stretching mode, $v_{\mathrm{s}}\left(\mathrm{UO}_{2}\right)$, is sensitive to changes in uranyl coordination environment; complexation of the uranyl(VI) ion weakens the $\mathrm{O}=\mathrm{U}=\mathrm{O}$ bonds, causing $v_{\mathrm{s}} \mathrm{UO}_{2}$ to shift to lower frequency. Thus, Raman spectroscopy may provide information regarding coordination environment of the uranyl ions dissolved in the IL system. Figure II-4 shows a typical Raman spectra of $[\mathrm{BMIM}]\left[\mathrm{Tf}_{2} \mathrm{~N}\right]$ with and without dissolved uranyl species. The vibrational bands at $825,908,884,1025$, and $1056 \mathrm{~cm}^{-1}$ visible in all four spectra arise from $[\mathrm{BMIM}]\left[\mathrm{Tf}_{2} \mathrm{~N}\right]$. The mode at $1025 \mathrm{~cm}^{-1}$ has been assigned to the in-plane symmetric stretching mode of the imidazolium ring. ${ }^{11}$ If only $\mathrm{UO}_{2}\left(\mathrm{NO}_{3}\right)_{2} \cdot 6 \mathrm{H}_{2} \mathrm{O}$ is dissolved in the IL (spectrum II-4b), the symmetric stretching mode, $v_{\mathrm{s}}\left(\mathrm{UO}_{2}\right)$, occurs at $868 \mathrm{~cm}^{-1}$, indicating the $\mathrm{O}=\mathrm{U}=\mathrm{O}$ bond strength is roughly the same as it is in aqueous solution at low $\mathrm{pH}$ values, where a band at 870 $\mathrm{cm}^{-1}$ arises from the solvated $\mathrm{UO}_{2}\left(\mathrm{H}_{2} \mathrm{O}\right)_{5}{ }^{2+}$ cation. ${ }^{12}$ From the spectroscopic data, it is reasonable to postulate that the uranyl cation is solvated in $[\mathrm{BMIM}]\left[\mathrm{Tf}_{2} \mathrm{~N}\right]$, but that the $\mathrm{O}=\mathrm{U}=\mathrm{O}$ bond is not perturbed. When TBP is added to the IL phase containing dissolved $\mathrm{UO}_{2}{ }^{2+}$, the $v_{\mathrm{s}}\left(\mathrm{UO}_{2}\right)$ band shifts to lower wavenumber, reaching a well-defined peak at $860 \mathrm{~cm}^{-1}$ when the molar ratio of TBP to uranyl reaches a value of 2 (spectrum II-4c). The shift to lower wavenumber upon addition of TBP to the IL solution indicates that the coordination environment of $\mathrm{UO}_{2}{ }^{2+}$ has changed and TBP is associated with the uranyl ion. To test the $\mathrm{P}=\mathrm{O}$ coordination with uranyl in the IL, TBPO (tri-n-butylphosphine oxide) was added to the IL/ $\mathrm{UO}_{2}\left(\mathrm{NO}_{3}\right)_{2} \cdot 6 \mathrm{H}_{2} \mathrm{O}$ solution, resulting in a shift of $v_{\mathrm{s}}\left(\mathrm{UO}_{2}\right)$ to $845 \mathrm{~cm}^{-1}$ (spectrum II-4d). The appearance of $v_{\mathrm{s}}\left(\mathrm{UO}_{2}\right)$ at a lower frequency for the uranyl-TBPO complex relative to $v_{\mathrm{s}}\left(\mathrm{UO}_{2}\right)$ for the uranyl-TBP complex is expected, as TBPO is a stronger Lewis base than TBP. 
Figure II-5 shows Raman spectra of the IL solutions having varying molar ratios of $\mathrm{UO}_{2}$ :TBP. The $v_{\mathrm{s}}\left(\mathrm{UO}_{2}\right)$ mode at $860 \mathrm{~cm}^{-1}$ does not change when the molar ratio of TBP/ $\mathrm{UO}_{2}$ exceeds 2 (Figure II-5). The Raman data suggest that probably two molecules of TBP are coordinated with each uranyl ion in [BMIM] $\left[\mathrm{Tf}_{2} \mathrm{~N}\right]$. In our Raman study we do not see the $v_{\mathrm{s}}\left(\mathrm{NO}_{3}\right)^{-}$mode, which normally appears at $1047 \mathrm{~cm}^{-1}$ in aqueous solutions of uranyl nitrate. ${ }^{13}$ Our spectra also do not show vibrational modes resulting from nitrate bound to uranyl ion (752 $\mathrm{cm}^{-1}, 1036 \mathrm{~cm}^{-1}, 1304 \mathrm{~cm}^{-1}$ in aqueous solutions). ${ }^{13}$ These peaks are likely buried under the [BMIM] $\left[\mathrm{Tf}_{2} \mathrm{~N}\right]$ spectrum. Earlier studies of nitric acid dissolution of $\mathrm{UO}_{2}$ in $[\mathrm{BMIM}]\left[\mathrm{Tf}_{2} \mathrm{~N}\right]$ using UV-Vis, EXAFS (extended X-ray absorption fine structure), and molecular dynamic simulations show the existence of a uranyl nitrato species $\mathrm{UO}_{2}\left(\mathrm{NO}_{3}\right)_{3}{ }^{-}$in the ionic liquid phase with excess amounts of nitrate. ${ }^{7,14}$ The presence of $\mathrm{UO}_{2}\left(\mathrm{NO}_{3}\right)_{3}{ }^{-}$in the IL would lead to the enhancement of absorption bands in the 420-480 nm range. ${ }^{7}$ These enhanced absorption bands are not observed in our IL system with $\operatorname{TBP}\left(\mathrm{HNO}_{3}\right)_{1.8}\left(\mathrm{H}_{2} \mathrm{O}\right)_{0.6}$. In our case of $\mathrm{UO}_{2}$ dissolution with TBP $\left(\mathrm{HNO}_{3}\right)_{1.8}\left(\mathrm{H}_{2} \mathrm{O}\right)_{0.6}$ in [BMIM] $\left[\mathrm{Tf}_{2} \mathrm{~N}\right]$, since 2 molecules of TBP are coordinated with the uranyl ion, the dissolved uranyl species is probably of the form $\mathrm{UO}_{2}(\mathrm{TBP})_{2}\left(\mathrm{NO}_{3}\right)_{\mathrm{x}}$ where $\mathrm{x}$ may be 1,2 or 3 . It is unlikely that the coordination number of uranium would allow formation of a uranyl-TBP-nitrate complex with $3 \mathrm{NO}_{3}{ }^{-}$. Charged $\mathrm{UO}_{2}(\mathrm{TBP})_{2}\left(\mathrm{NO}_{3}\right)^{+}$species $(\mathrm{x}=1)$ is not extractable by supercritical $\mathrm{CO}_{2}$. Formation of neutral $\mathrm{UO}_{2}(\mathrm{TBP})_{2}\left(\mathrm{NO}_{3}\right)_{2}$ in our IL system is very likely. Neutral uranyl complexes extracted from nitric acid solutions into ionic liquids are known in the literature. ${ }^{15,16}$ However, the possibility of forming aggregates of uranyl-TBPnitrate complexes in the IL phase with different $x$ values ( $x=1,2$, and 3 ) cannot be ruled out. It is also possible that $\mathrm{HNO}_{3}$ molecules may be attached to the uranyl-TBP-nitrate complexes forming $\mathrm{UO}_{2}(\mathrm{TBP})_{2}\left(\mathrm{NO}_{3}\right)_{\mathrm{x}} \cdot\left(\mathrm{HNO}_{3}\right)_{\mathrm{y}}$ adducts in the IL phase. Formation of $\mathrm{UO}_{2}(\mathrm{TBP})_{2}\left(\mathrm{NO}_{3}\right)_{2} \cdot \mathrm{HNO}_{3}$ in dodecane-TBP extraction of uranyl ions from high concentrations of nitric acid solutions has been reported in the literature. ${ }^{17}$ Further research is needed to fully understand nitrate and $\mathrm{HNO}_{3}$ coordination with the uranyl-TBP species dissolved in the IL system. 


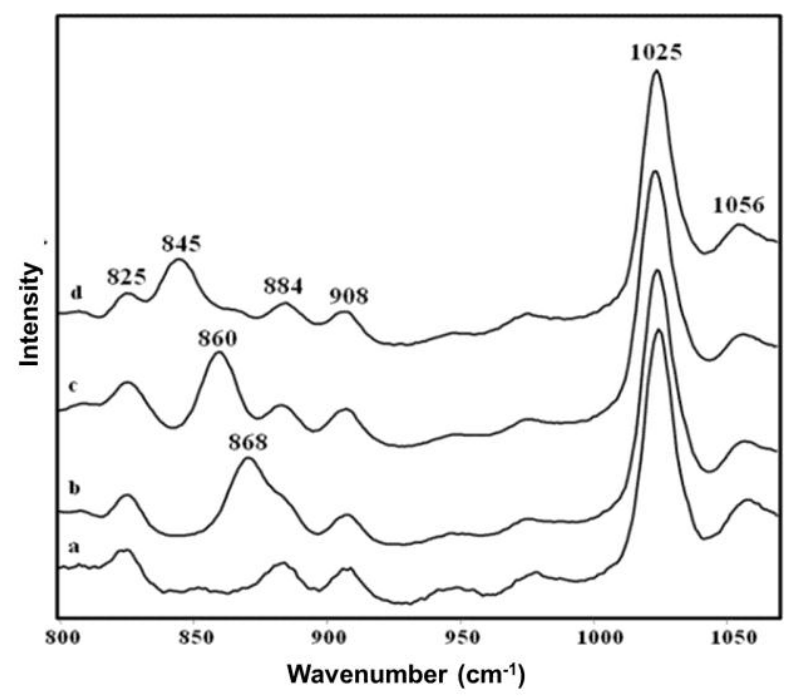

Figure II-4. Raman spectra of (a) $[\mathrm{BMIM}]\left[\mathrm{Tf}_{2} \mathrm{~N}\right]$ only, (b) $0.17 \mathrm{M} \mathrm{UO}_{2}\left(\mathrm{NO}_{3}\right)_{2} \cdot 6 \mathrm{H}_{2} \mathrm{O}$ in [BMIM] $\left[\mathrm{Tf}_{2} \mathrm{~N}\right.$ ], (c) $0.17 \mathrm{M} \mathrm{UO}_{2}\left(\mathrm{NO}_{3}\right)_{2} \cdot 6 \mathrm{H}_{2} \mathrm{O}$ and $0.34 \mathrm{M}$ TBP in [BMIM] $\left[\mathrm{Tf}_{2} \mathrm{~N}\right.$ ], and (d) $0.17 \mathrm{M}$ $\mathrm{UO}_{2}\left(\mathrm{NO}_{3}\right)_{2} \cdot 6 \mathrm{H}_{2} \mathrm{O}$ and $0.34 \mathrm{M}$ TBPO in [BMIM] $\left[\mathrm{Tf}_{2} \mathrm{~N}\right]$.

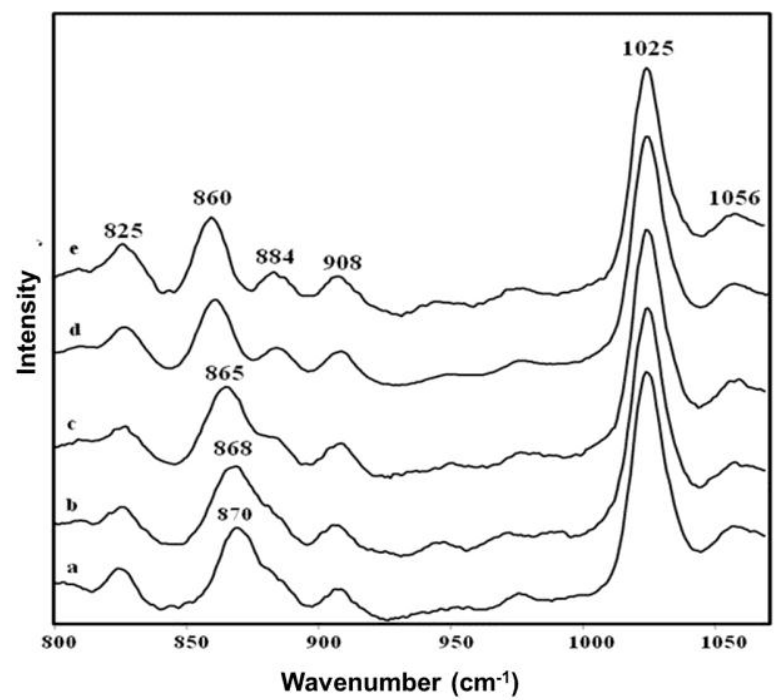

Figure II-5. Raman spectra of the IL solution with different molar ratio of $\mathrm{UO}_{2}$ : TBP (a) 1 : 0.25 , (b) $1: 0.5$, (c) $1: 1$, (d) $1: 2$, and (e) $1: 3$.

\section{II-3. Transferring Uranium from IL Phase to sc-CO}

The IL containing dissolved uranium species from the cumulative $\mathrm{UO}_{2}$ dissolution experiment was placed in a high pressure fiber-optic cell connected to a CCD array UV/vis spectrometer for static supercritical fluid extraction (SFE) studies. A description of the high- 
pressure fiber-optic device was reported in the literature. ${ }^{3}$ The cell was preheated to $40{ }^{\circ} \mathrm{C}$ and pressurized with $200 \mathrm{~atm}$ of $\mathrm{CO}_{2}$. The SFE process was also monitored by Raman spectrometer and the spectrum of the $\mathrm{CO}_{2}$ phase after $30 \mathrm{~min}$ of static extraction time is shown in Figure II-6a. The Raman peak at $860 \mathrm{~cm}^{-1}$ is identical to the peak position for synthesized $\mathrm{UO}_{2}\left(\mathrm{NO}_{3}\right)_{2}(\mathrm{TBP})_{2}$ dissolved directly in sc- $\mathrm{CO}_{2}$. This Raman peak in $\mathrm{sc}-\mathrm{CO}_{2}$ is also the same as that observed for the dissolved uranyl species in the IL shown in Figure II-4c and Figure II-5d. The Raman study suggests $\mathrm{UO}_{2}$ dissolved in $[\mathrm{BMIM}]\left[\mathrm{Tf}_{2} \mathrm{~N}\right]$ with $\mathrm{TBP}\left(\mathrm{HNO}_{3}\right)_{1.8}\left(\mathrm{H}_{2} \mathrm{O}\right)_{0.6}$ may exist as the neutral $\mathrm{UO}_{2}\left(\mathrm{NO}_{3}\right)_{2}(\mathrm{TBP})_{2}$ compound in the IL phase.

Extraction of the uranium species from the IL phase to the $\mathrm{sc}-\mathrm{CO}_{2}$ at $40{ }^{\circ} \mathrm{C}$ and $200 \mathrm{~atm}$ is virtually complete in $<10$ minutes indicating the mass transfer of the uranyl complex from $[\mathrm{BMIM}]\left[\mathrm{Tf}_{2} \mathrm{~N}\right]$ to $\mathrm{sc}-\mathrm{CO}_{2}$ phase is very rapid. Without TBP in the system, uranyl nitrate dissolved in $[\mathrm{BMIM}]\left[\mathrm{Tf}_{2} \mathrm{~N}\right]$ is not extractable by $\mathrm{sc}-\mathrm{CO}_{2}$. The solubility of $\mathrm{UO}_{2}\left(\mathrm{NO}_{3}\right)_{2}(\mathrm{TBP})_{2}$ in sc- $\mathrm{CO}_{2}$ at $40{ }^{\circ} \mathrm{C}$ and 200 atm is about 0.45 moles per liter. ${ }^{3}$ The amount of uranium and the volume of the sc- $\mathrm{CO}_{2}$ extraction cell used in our experiments would not reach $10 \%$ of the solubility limit. Figure $6 \mathrm{~b}$ shows the UV-Vis spectrum of the uranyl species dissolved in the supercritical fluid $\mathrm{CO}_{2}$ phase obtained by the high-pressure fiberoptic cell. The spectrum is similar to that reported in the literature for synthesized $\mathrm{UO}_{2}(\mathrm{TBP})_{2}\left(\mathrm{NO}_{3}\right)_{2}$ in sc- $\mathrm{CO}_{2}$ except the intensities of the peaks at $425 \mathrm{~nm}$ and above are enhanced. ${ }^{3}$ The enhanced peak intensities in this region may be attributed to the formation of an $\mathrm{HNO}_{3}$ adduct such as $\mathrm{UO}_{2}(\mathrm{TBP})_{2}\left(\mathrm{NO}_{3}\right)_{2} \cdot \mathrm{HNO}_{3}$, as observed in the solvent extraction experiments. ${ }^{17}$ The uranyl species extracted into sc- $\mathrm{CO}_{2}$ can be recovered by depressurizing the exit fluid and collected in an acetone trap solution. The UV-Vis spectrum of the acetone trap solution shown in Figure II$6 \mathrm{c}$ is similar to that found in the $\mathrm{sc}-\mathrm{CO}_{2}$ phase. When the acetone trap solution was evaporated to near dryness in a beaker and dodecane and water were added, the absorption spectrum of the dodecane phase was identical to that of $\mathrm{UO}_{2}(\mathrm{TBP})_{2}\left(\mathrm{NO}_{3}\right)_{2}$ (Figure II-6d) and the aqueous phase was acidic. In addition, FT-IR spectra reveal that the $\mathrm{HNO}_{3}$ adduct peak $\left(1648 \mathrm{~cm}^{-1}\right)$ observed in the acetone trap solution was absent in the dodecane trap solution. The $\mathrm{UO}_{2}(\mathrm{TBP})_{2}\left(\mathrm{NO}_{3}\right)_{2} \cdot \mathrm{HNO}_{3}$ adduct is known to be unstable in contact with organic phase and/or water according to the literature. ${ }^{17}$ When the exit fluid was bubbled through a water-dodecane trap solution, the uranyl species collected in the dodecane phase showed an absorption spectrum identical to that of Figure II-6d. 

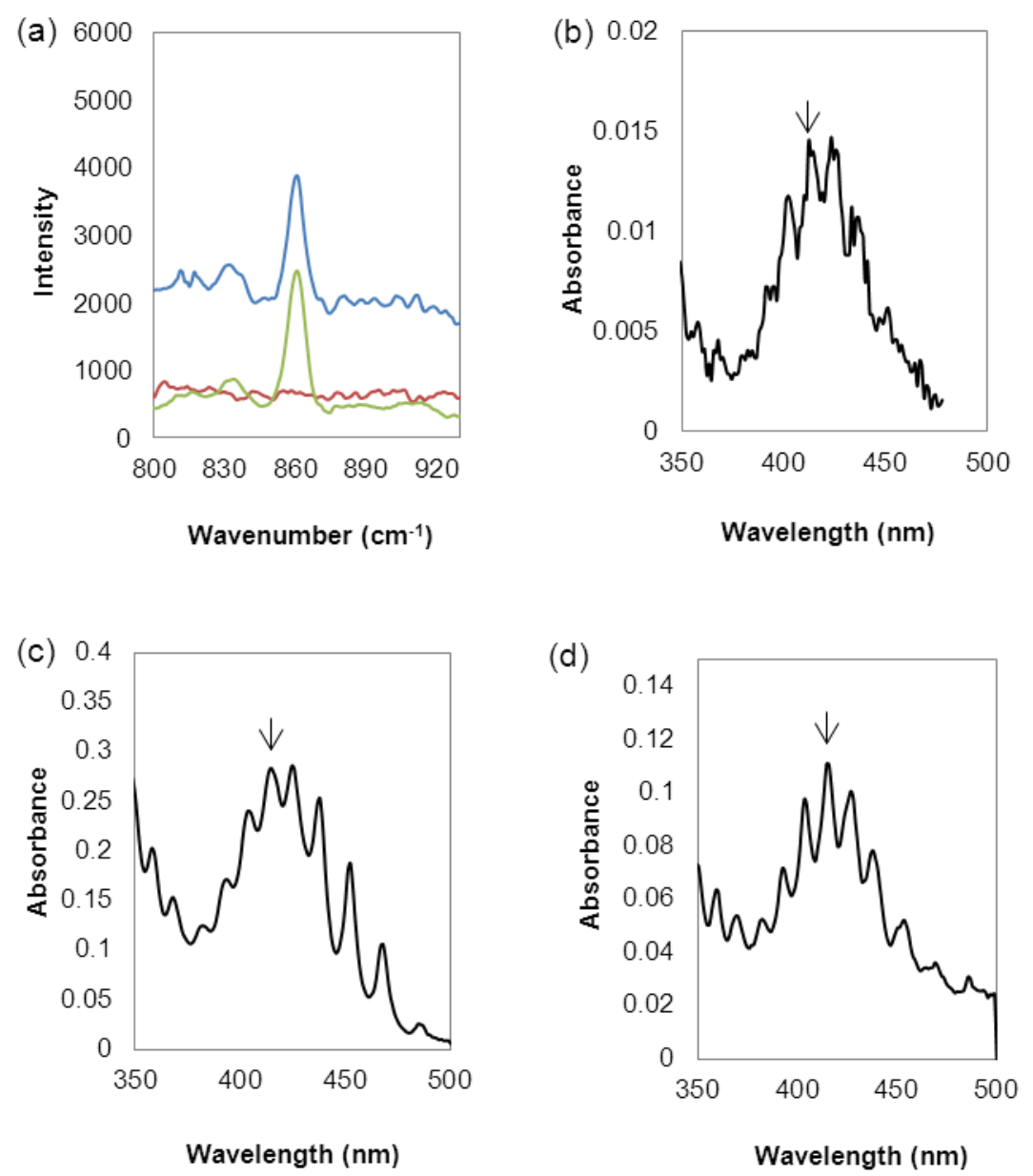

Figure II-6. (a) Raman spectra of uranyl species in sc- $\mathrm{CO}_{2}$. Red: sc- $\mathrm{CO}_{2}$ background; green: standard $\mathrm{UO}_{2}\left(\mathrm{NO}_{3}\right)_{2}(\mathrm{TBP})_{2}$ dissolved in $\mathrm{sc}-\mathrm{CO}_{2}$; blue: uranyl species extracted from [BMIM] $\left[\mathrm{Tf}_{2} \mathrm{~N}\right]$ into sc- $\mathrm{CO}_{2}$ (30 min of static extraction at $40{ }^{\circ} \mathrm{C}$ and $\left.200 \mathrm{~atm}\right)$; (b) in situ UV/Vis spectrum of the uranyl species extracted into the $\mathrm{sc}-\mathrm{CO}_{2}$ phase; (c) UV/Vis spectrum of the uranyl species collected in an acetone trap solution; (d) UV/Vis spectrum of the uranyl species collected in a dodecane solution.

\section{II-4. Summary}

The dissolution of $\mathrm{UO}_{2}$ in $[\mathrm{BMIM}]\left[\mathrm{Tf}_{2} \mathrm{~N}\right]$ with $\mathrm{TBP}\left(\mathrm{HNO}_{3}\right)_{1.8}\left(\mathrm{H}_{2} \mathrm{O}\right)_{0.6}$ at room temperature follows pseudo first-order kinetics initially. The maximum amount of $\mathrm{UO}_{2}$ dissolution is about $320 \mathrm{mg}$ in $3.6 \mathrm{~mL}$ of $[\mathrm{BMIM}]\left[\mathrm{Tf}_{2} \mathrm{~N}\right]$ containing $16.7 \%$ by volume of the $\operatorname{TBP}\left(\mathrm{HNO}_{3}\right)_{1.8}\left(\mathrm{H}_{2} \mathrm{O}\right)_{0.6}$ complex. Raman spectra show the dissolved uranyl species is coordinated with TBP in the IL phase with a uranyl:TBP molar ratio of 1:2, suggesting the formation of uranyl-TBP complexes of a general form $\mathrm{UO}_{2}(\mathrm{TBP})_{2}\left(\mathrm{NO}_{3}\right)_{\mathrm{x}}$ where $\mathrm{x}$ may be 1,2 , and 3. The uranium species dissolved in the IL can be rapidly extracted into sc-CO $\mathrm{CO}_{2} \mathrm{UV}-\mathrm{Vis}$ 
spectra indicate the presence of an $\mathrm{UO}_{2}\left(\mathrm{NO}_{3}\right)_{2}(\mathrm{TBP})_{2}$ and $\mathrm{HNO}_{3}$ adduct probably of the form $\mathrm{UO}_{2}\left(\mathrm{NO}_{3}\right)_{2}(\mathrm{TBP})_{2} \cdot \mathrm{HNO}_{3}$. The $\mathrm{HNO}_{3}$ adduct dissociates in contact with a water-dodecane trap solution during depressurization of the system. The uranyl species collected in the dodecane phase is $\mathrm{UO}_{2}\left(\mathrm{NO}_{3}\right)_{2}(\mathrm{TBP})_{2}$. No aqueous phase is formed either in the IL dissolution step or in the sc- $\mathrm{CO}_{2}$ extraction step. 


\section{Chapter III. Kinetic Study on Dissolution of Uranium Dioxide and Neodymium Sesquioxide in Ionic Liquid}

Little is known in the literature regarding kinetics parameters for direct dissolution of solid oxide particles of the f-block elements in IL. This kind of kinetics information is essential for developing IL-based technologies for nuclear waste management. Some preliminary data regarding the rate of dissolution of uranium dioxide in the ionic liquid consisting of a 1-butyl-3methylimidazolium [Bmim] cation and a bis-(trifluoromethane)sulphonimide $\left(\mathrm{Tf}_{2} \mathrm{~N}\right)$ anion are presented in the previous chapter. In this chapter, the details of the dissolution behavior of uranium dioxide $\left(\mathrm{UO}_{2}\right)$ and neodymium sesquioxide $\left(\mathrm{Nd}_{2} \mathrm{O}_{3}\right)$ solid particles in the IL $[\mathrm{Bmim}]\left[\mathrm{Tf}_{2} \mathrm{~N}\right]$ using $\mathrm{TBP}\left(\mathrm{HNO}_{3}\right)_{1.8}\left(\mathrm{H}_{2} \mathrm{O}\right)_{0.6}$ as an oxidizing/complexing agent are presented. The effects of temperature on the dissolution processes are investigated and the activation energies $\left(E_{a}\right)$, enthalpies $\left(\Delta H^{\ddagger}\right)$, and entropies $\left(\Delta S^{\ddagger}\right)$ of activation for the formation of uranylnitrate-TBP and Nd-nitrate-TBP complexes in the IL are evaluated. The effect of water on the dissolution of $\mathrm{UO}_{2}$ in the IL phase is also described.

\section{III-1. Rate of Dissolution of $\mathrm{UO}_{2}$ and $\mathrm{Nd}_{2} \mathrm{O}_{3}$ in $\mathrm{RTIL}$}

The $\operatorname{TBP}\left(\mathrm{HNO}_{3}\right)_{1.8}\left(\mathrm{H}_{2} \mathrm{O}\right)_{0.6}$ complex is miscible with $[\mathrm{Bmim}]\left[\mathrm{Tf}_{2} \mathrm{~N}\right]$, forming one homogeneous liquid phase at the volume ratio 1:5. $\mathrm{UO}_{2}$ powder $(200-270$ mesh or 74-53 $\mu \mathrm{m})$ or $\mathrm{Nd}_{2} \mathrm{O}_{3}$ powder (325-400 mesh or 44-37 $\mu \mathrm{m}$ ) was individually added to [Bmim] $\left[\mathrm{Tf}_{2} \mathrm{~N}\right]$ containing the $\mathrm{TBP}-\mathrm{HNO}_{3}$ complex. The dissolution process was monitored at 424 and $437 \mathrm{~nm}$ for $\mathrm{UO}_{2}$ and at 801 and $872 \mathrm{~nm}$ for $\mathrm{Nd}_{2} \mathrm{O}_{3}$ by acquiring UV/Vis spectra of the IL phase at different times (Figure III-1a and 1b). All spectra were normalized to $480 \mathrm{~nm}$ for dissolution of $\mathrm{UO}_{2}$ and 890 $\mathrm{nm}$ for dissolution of $\mathrm{Nd}_{2} \mathrm{O}_{3}$. The percentages of dissolution of $\mathrm{UO}_{2}$ and $\mathrm{Nd}_{2} \mathrm{O}_{3}$ in IL at room temperature with respect to time are given in Figures III-2a and $2 b$. For $\mathrm{UO}_{2}$ dissolution, about $81 \%$ of the oxide is dissolved in the IL in the first hour and another $16 \%$ in the second hour. For $\mathrm{Nd}_{2} \mathrm{O}_{3}$ dissolution, approximately $98 \%$ of the oxide is dissolved in the IL phase in the first hour. The rate of dissolution of $\mathrm{UO}_{2}$ is slower than that of $\mathrm{Nd}_{2} \mathrm{O}_{3}$ probably because an oxidation step, i.e. from $\mathrm{U}(\mathrm{IV})$ to $\mathrm{U}(\mathrm{VI})$, is involved in the former case 

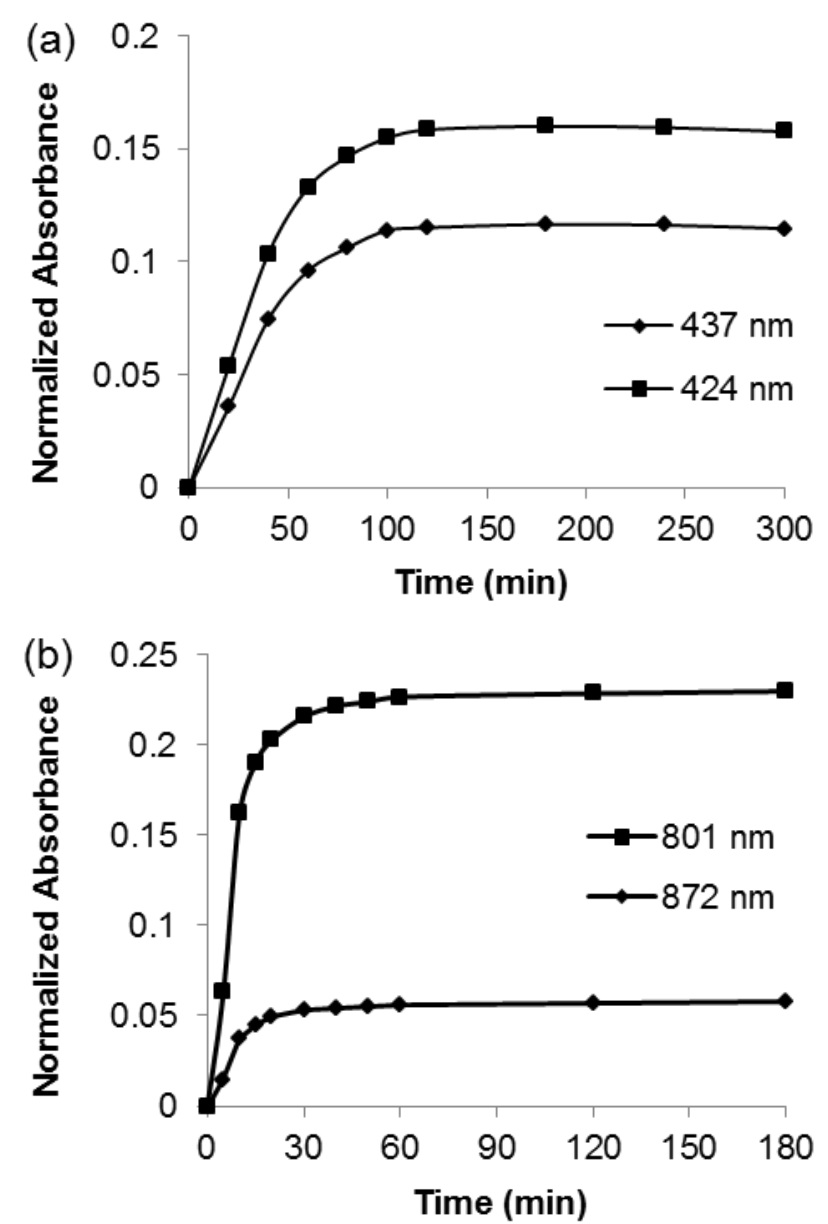

Figure III-1. (a) Variation of absorbance with time for dissolution of $\mathrm{UO}_{2}$ (s) measured at 424 and at $437 \mathrm{~nm}$; (b) dissolution of $\mathrm{Nd}_{2} \mathrm{O}_{3}(\mathrm{~s})$ measured at 801 and at $872 \mathrm{~nm}$ in [Bmim] [Tf $\left.2 \mathrm{~N}\right]$ with $\operatorname{TBP}\left(\mathrm{HNO}_{3}\right)_{1.8}\left(\mathrm{H}_{2} \mathrm{O}\right)_{0.6}$ at room temperature.

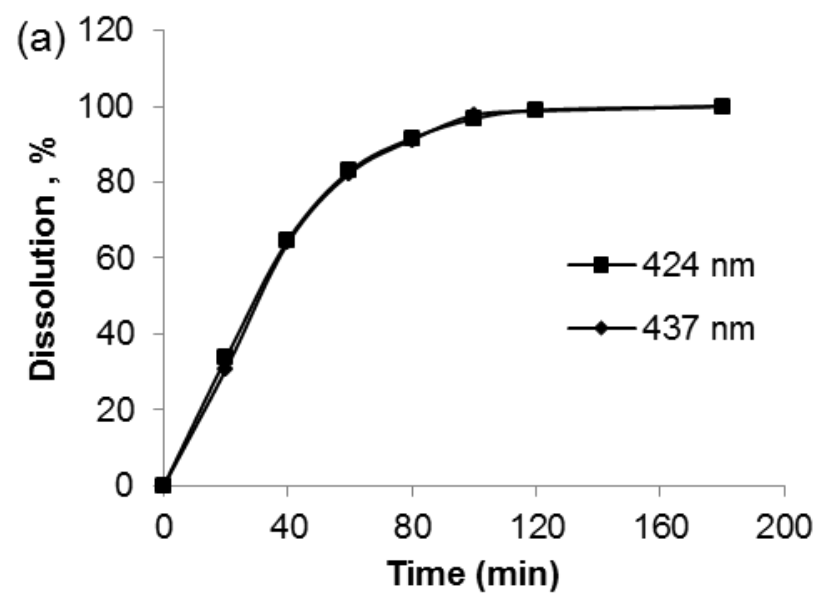




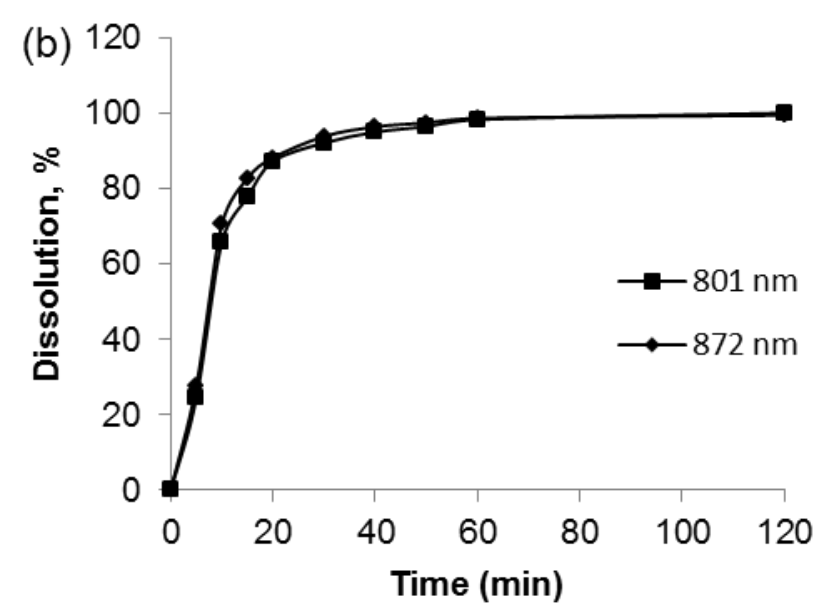

Figure III-2. Percent of oxide dissolution in IL with respect to time (a) dissolution of $\mathrm{UO}_{2}$ and (b) dissolution of $\mathrm{Nd}_{2} \mathrm{O}_{3}$ at room temperature in $[\mathrm{Bmim}]\left[\mathrm{Tf}_{2} \mathrm{~N}\right]$ with $\mathrm{TBP}\left(\mathrm{HNO}_{3}\right)_{1.8}\left(\mathrm{H}_{2} \mathrm{O}\right)_{0.6}$.

The dissolution of $\mathrm{UO}_{2}$ in the IL with $\mathrm{TBP}\left(\mathrm{HNO}_{3}\right)_{1.8}\left(\mathrm{H}_{2} \mathrm{O}\right)_{0.6}$ probably involves several steps including the oxidation of $\mathrm{UO}_{2}$ to $\left(\mathrm{UO}_{2}\right)^{2+}$, formation of uranyl-nitrate-TBP complex and diffusion of the reactant and the product in the solid-liquid interface. Since the dissolution experiments are carried out under rapid stirring, the diffusion effect may be neglected. Dissolution of $\mathrm{UO}_{2}$ in aqueous nitric acid is known to consist of an oxidation step which can be expressed as ${ }^{18}$ :

$\mathrm{UO}_{2}+8 / 3 \mathrm{HNO}_{3} \rightarrow \mathrm{UO}_{2}\left(\mathrm{NO}_{3}\right)_{2}+2 / 3 \mathrm{NO}+4 / 3 \mathrm{H}_{2} \mathrm{O}$

Assuming $\mathrm{UO}_{2}$ dissolution in the IL containing $\mathrm{TBP}\left(\mathrm{HNO}_{3}\right)_{1.8}\left(\mathrm{H}_{2} \mathrm{O}\right)_{0.6}$ forms a neutral $\mathrm{UO}_{2}\left(\mathrm{NO}_{3}\right)_{2}(\mathrm{TBP})_{2}$ complex, the dissolution reaction can be simplified as:

$\mathrm{UO}_{2}+8 / 3 \mathrm{HNO}_{3}+2 \mathrm{TBP} \stackrel{\mathrm{k}_{1}}{\rightarrow} \mathrm{UO}_{2}\left(\mathrm{NO}_{3}\right)_{2}(\mathrm{TBP})_{2}+2 / 3 \mathrm{NO}+4 / 3 \mathrm{H}_{2} \mathrm{O}$

Dissolution of $\mathrm{Nd}_{2} \mathrm{O}_{3}$ in the IL with $\operatorname{TBP}\left(\mathrm{HNO}_{3}\right)_{1.8}\left(\mathrm{H}_{2} \mathrm{O}\right)_{0.6}$ leads to the formation of $\mathrm{Nd}\left(\mathrm{NO}_{3}\right)_{3}(\mathrm{TBP})_{3}$ according to our UV/Vis spectroscopic information. Therefore, the dissolution of $\mathrm{Nd}_{2} \mathrm{O}_{3}$ may be expressed by the following simplified equation:

$$
\mathrm{Nd}_{2} \mathrm{O}_{3}+6 \mathrm{HNO}_{3}+6 \mathrm{TBP} \stackrel{\mathrm{k}_{2}}{\longrightarrow} 2 \mathrm{Nd}\left(\mathrm{NO}_{3}\right)_{3}(\mathrm{TBP})_{3}+3 \mathrm{H}_{2} \mathrm{O}
$$

According to the literature, the dissolution rate of solid $\mathrm{UO}_{2}$ particles in nitric acid depends on the surface area of the particle. ${ }^{19}$ A simple equation can be expressed as:

$$
\frac{\mathrm{dC}}{\mathrm{dt}}=\frac{\mathrm{kSN}}{\mathrm{V}}
$$


where $\mathrm{C}$ is the concentration of uranyl (mol/L), $\mathrm{S}$ is the surface of area of each $\mathrm{UO}_{2}$ particle $\left(\mathrm{cm}^{2}\right), \mathrm{N}$ is the number of $\mathrm{UO}_{2}$ particles, and $\mathrm{V}$ is the volume of the solution $(\mathrm{L})$. The dissolution rates of $\mathrm{UO}_{2}$ and $\mathrm{Nd}_{2} \mathrm{O}_{3}$ in $[\mathrm{Bmim}]\left[\mathrm{Tf}_{2} \mathrm{~N}\right]$ with $\mathrm{TBP}\left(\mathrm{HNO}_{3}\right)_{1.8}\left(\mathrm{H}_{2} \mathrm{O}\right)_{0.6}$ should also depend on the stirring speed. Our experiments indicated that the rate of dissolution of $\mathrm{UO}_{2}$ in the IL system was independent of stirring speed above $1050 \mathrm{rpm}$. Therefore, all dissolution experiments in this study were carried out at a stirring speed of $1200 \pm 10 \mathrm{rpm}$. Stirring is always required in conventional nitric acid dissolution of $\mathrm{UO}_{2}$, but the speed is usually much lower compared with our IL dissolution process due to the high viscosity of IL. To evaluate the dissolution rate constant of $\mathrm{UO}_{2}$ or $\mathrm{Nd}_{2} \mathrm{O}_{3}$ in the IL system, we made the following assumptions: (1) the metal oxide particles were spherical, (2) the solutions were well-mixed and well distributed in the reaction flask, (3) temperature and pressure were uniformly distributed during the dissolution process, and (4) the convective mass transfer resistance could be neglected. Based on these assumptions, the dissolution rate constant $\left(\mathrm{k}\right.$ in $\left.\mathrm{mol} \cdot \mathrm{cm}^{-2} \cdot \mathrm{min}^{-1}\right)$ can be expressed as:

$$
\begin{aligned}
& \mathrm{k}=-\left(\frac{\rho}{\mathrm{M}}\right)\left(\frac{\mathrm{dr}}{\mathrm{dt}}\right) \\
& \mathrm{r}=\mathrm{r}_{0}-(\mathrm{kM} / \rho) \mathrm{t}
\end{aligned}
$$

where $\rho$ is the density of $\mathrm{UO}_{2}$ or $\mathrm{Nd}_{2} \mathrm{O}_{3}\left(\mathrm{~g} / \mathrm{cm}^{3}\right), \mathrm{r}_{0}$ is the initial radius of $\mathrm{UO}_{2}$ or $\mathrm{Nd}_{2} \mathrm{O}_{3}$ particle $(\mathrm{cm}), \mathrm{r}$ is the radius of the metal oxide at time $\mathrm{t}$, and $\mathrm{M}$ is the molecular weight of the oxide. If our assumptions are reasonable, a plot of radius versus time should give a straight line with a slop of $\mathrm{kM} / \rho$. The change in radius of $\mathrm{UO}_{2}$ or $\mathrm{Nd}_{2} \mathrm{O}_{3}$ particles during the dissolution process can be obtained by the following equation ${ }^{5}$

$$
\mathrm{r}=\mathrm{r}_{0}\left(1-\left(\mathrm{C}_{\mathrm{A}} / \mathrm{C}_{\infty}\right)^{1 / 3}\right.
$$

where $\mathrm{C}_{\mathrm{A}}$ is the concentration of $\mathrm{UO}_{2}$ or $\mathrm{Nd}_{2} \mathrm{O}_{3}$ dissolved in the $\mathrm{IL}$ at time $\mathrm{t}$ and $\mathrm{C}_{\infty}$ is the concentration of $\mathrm{UO}_{2}$ or $\mathrm{Nd}_{2} \mathrm{O}_{3}$ dissolved completely in the IL phase. In the present study, the initial radius $\left(\mathrm{r}_{0}\right)$ was taken as the average value of the known range of the oxide particle sizes. For example, for 200-270 mesh $\mathrm{UO}_{2}$ particles, the diameters of the particles should range from 53 to $74 \mu \mathrm{m}$. The average radius is $31.7 \mu \mathrm{m}$ or $3.17 \times 10^{-3} \mathrm{~cm}$ which is taken as the $\mathrm{r}_{0}$ value for the $\mathrm{UO}_{2}$ particles. Using the same approach, the $325-400$ mesh $\mathrm{Nd}_{2} \mathrm{O}_{3}$ particles $(37-44 \mu \mathrm{m}$ diameter) should have an average radius or $\mathrm{r}_{0}=20.3 \mu \mathrm{m}$ or $2.03 \times 10^{-3} \mathrm{~cm}$. 
Plots of radius versus time for dissolution of individual $\mathrm{UO}_{2}$ and $\mathrm{Nd}_{2} \mathrm{O}_{3}$ at room temperature are shown in Figure III-3. A linear relationship is observed which suggests that our assumptions are reasonable. The slope of the line is $2 \times 10^{-5}$ for $\mathrm{UO}_{2}$ and $6 \times 10^{-5}$ for $\mathrm{Nd}_{2} \mathrm{O}_{3}$. The rate constants (k) of $\mathrm{UO}_{2}$ and $\mathrm{Nd}_{2} \mathrm{O}_{3}$ dissolutions are calculated to be $8.13 \times 10^{-7}$ and $1.29 \times 10^{-6} \mathrm{~mol} \cdot \mathrm{cm}^{-2}$. $\min ^{-1}$, respectively. The dissolution rate of $\mathrm{UO}_{2}$ is slower than that of $\mathrm{Nd}_{2} \mathrm{O}_{3}$ probably because the dissolution of $\mathrm{UO}_{2}$ involves an oxidation step. Dissolution of $\mathrm{UO}_{2}$ in $8 \mathrm{M}$ nitric acid was reported by Taylor et al. to have a rate constant of about $3.7 \times 10^{-7} \mathrm{~mol} \cdot \mathrm{cm}^{-2} \cdot \mathrm{min}^{-1}$ at $20{ }^{\circ} \mathrm{C}^{20}$ The rate of dissolution of $\mathrm{UO}_{2}$ in the IL containing $\operatorname{TBP}\left(\mathrm{HNO}_{3}\right)_{1.8}\left(\mathrm{H}_{2} \mathrm{O}\right)_{0.6}$ is about a factor of 2 faster than reported for its dissolution in $8 \mathrm{M}$ nitric acid.
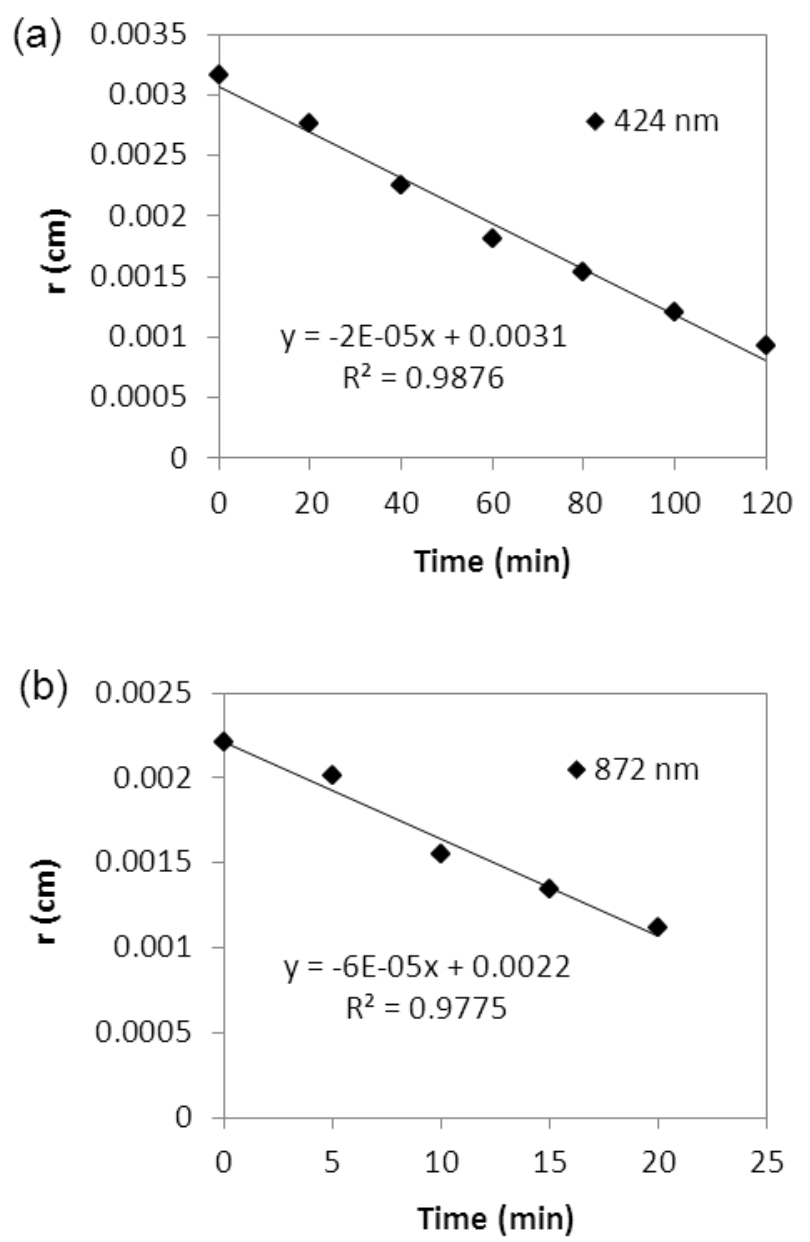

Figure III-3. Plot of radius versus time (a) for dissolution of $\mathrm{UO}_{2}$ (b) for dissolution of $\mathrm{Nd}_{2} \mathrm{O}_{3}$ in $[\mathrm{Bmim}]\left[\mathrm{Tf}_{2} \mathrm{~N}\right]$ containing $\mathrm{TBP}\left(\mathrm{HNO}_{3}\right)_{1.8}\left(\mathrm{H}_{2} \mathrm{O}\right)_{0.6}$ at room temperature. 


\section{III-2. Temperature Effect on Dissolution of $\mathrm{UO}_{2}$ and $\mathrm{Nd}_{2} \mathrm{O}_{3}$}

The rate of dissolution of $\mathrm{UO}_{2}$ in $[\mathrm{Bmim}]\left[\mathrm{Tf}_{2} \mathrm{~N}\right]$ with $\mathrm{TBP}\left(\mathrm{HNO}_{3}\right)_{1.8}\left(\mathrm{H}_{2} \mathrm{O}\right)_{0.6}$ increases with temperature in the temperature range $25-40{ }^{\circ} \mathrm{C}$ as shown in Figure III-4a. A linear relationship between $r$ and time is observed for all four sets of the experimental data given in Figure III-4b. The temperature dependence study ends at $40{ }^{\circ} \mathrm{C}$, because above this temperature the rate of dissolution of $\mathrm{UO}_{2}$ is too fast for our system to collect reproducible data for kinetic analysis. The dissolution rate constants at different temperatures can be obtained from Figure III-4b by the same method described in the previous section. Figure III-5 shows the rate of dissolution of $\mathrm{Nd}_{2} \mathrm{O}_{3}$ in the IL with respect to temperature in the temperature range $22-35^{\circ} \mathrm{C}$. In the case of $\mathrm{Nd}_{2} \mathrm{O}_{3}$, the rate of dissolution of the oxide above $35{ }^{\circ} \mathrm{C}$ is too fast for us to collect reproducible data.
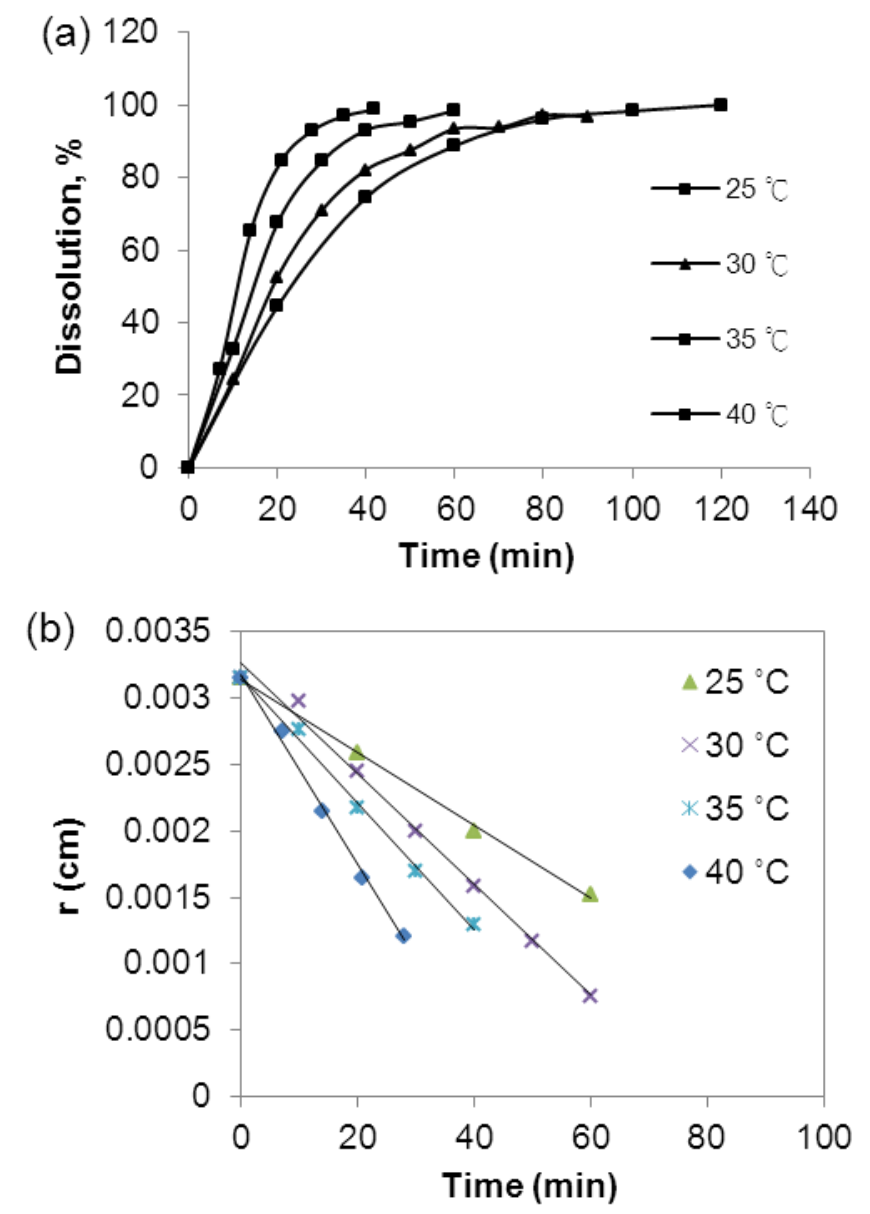

Figure III-4. Rate of dissolution of $\mathrm{UO}_{2}(\mathrm{~s})$ in $[\mathrm{Bmim}]\left[\mathrm{Tf}_{2} \mathrm{~N}\right]$ with $\mathrm{TBP}\left(\mathrm{HNO}_{3}\right)_{1.8}\left(\mathrm{H}_{2} \mathrm{O}\right)_{0.6}(16.7 \%$ by volume) at different temperature: (a) percentage of dissolved uranyl species versus time for $\mathrm{UO}_{2}$ dissolution; (b) $\mathrm{r}$ versus time plot. The rate constant for $\mathrm{UO}_{2}$ dissolution can be calculated from each slope. 

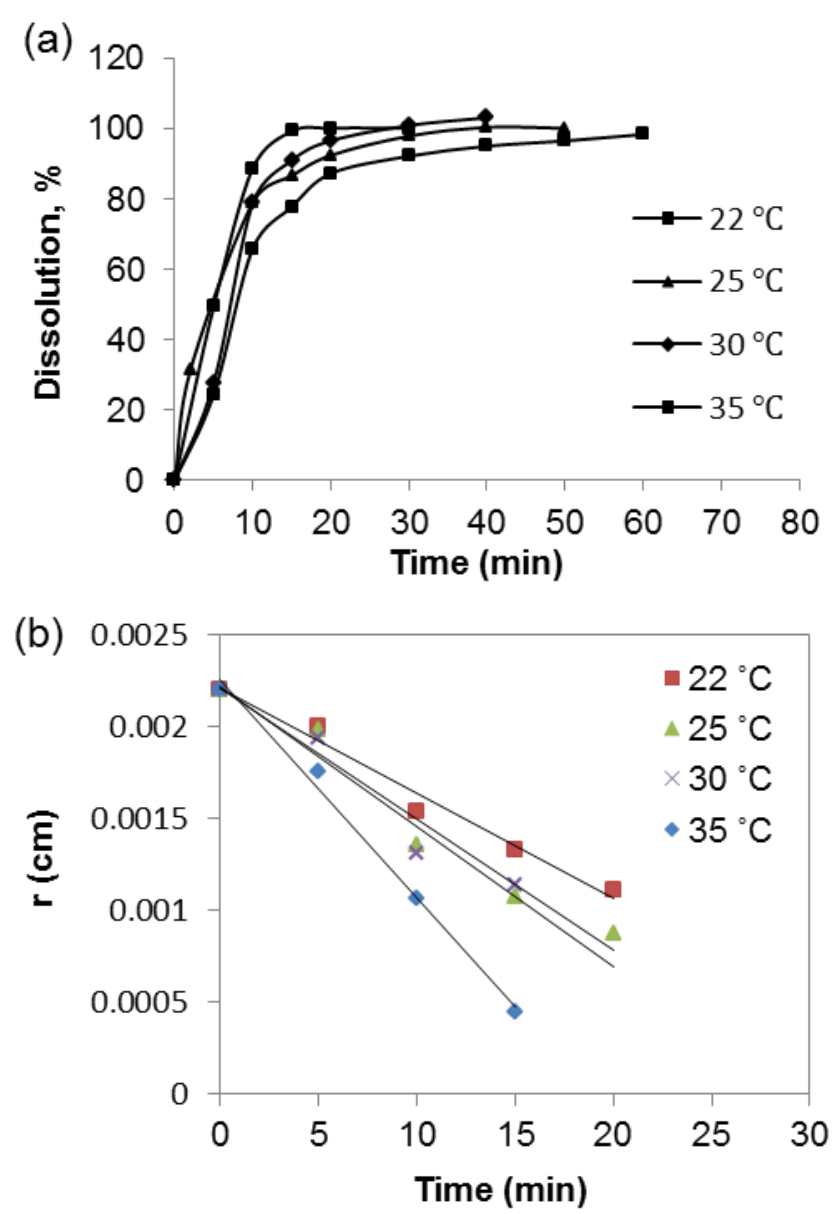

Figure III-5. Rate of dissolution of $\mathrm{Nd}_{2} \mathrm{O}_{3}(\mathrm{~s})$ in $[\mathrm{Bmim}]\left[\mathrm{Tf}_{2} \mathrm{~N}\right]$ with $\mathrm{TBP}\left(\mathrm{HNO}_{3}\right)_{1.8}\left(\mathrm{H}_{2} \mathrm{O}\right)_{0.6}$ (16.7\% by volume) at different temperature: (a) percentage of dissolved neodymium species versus time for $\mathrm{Nd}_{2} \mathrm{O}_{3}$ dissolution; (b) $\mathrm{r}$ versus time plot. The rate constant of $\mathrm{Nd}_{2} \mathrm{O}_{3}$ dissolution can be calculated from each slope.

The activation energy (Ea) of dissolution of $\mathrm{UO}_{2}$ can be obtained from Arrhenius equation, where $\mathrm{k}$ is reaction rate constant, Ea is energy of activation, $\mathrm{T}$ is absolute temperature, $\mathrm{R}$ is the ideal gas constant, and $\mathrm{A}$ is the pre-exponential factor.

$$
\ln \mathrm{k}=-\frac{\mathrm{E}_{\mathrm{a}}}{\mathrm{RT}}+\ln \mathrm{A}
$$

A plot of (ln k) versus (1/T) for dissolution of $\mathrm{UO}_{2}$ is shown in Figure III-6a. The activation energy is calculated to be $46.3 \pm 4.8 \mathrm{~kJ} \mathrm{~mol}^{-1}$ for $\mathrm{UO}_{2}$. Using the same approach, the activation energy for the dissolution of $\mathrm{Nd}_{2} \mathrm{O}_{3}$ is calculated to be $31.6 \pm 3.2 \mathrm{~kJ} \mathrm{~mol}^{-1}$ (Figure III-6b). Comparing our activation energy for dissolution of $\mathrm{UO}_{2}$ in IL to that reported for its dissolution in nitric acid (i.e. $62.7 \mathrm{~kJ} \mathrm{~mol}^{-1}$ ), ${ }^{20}$ the $\mathrm{E}_{\mathrm{a}}$ value is lower by $16.4 \mathrm{~kJ} \mathrm{~mol}^{-1}$ for dissolution of $\mathrm{UO}_{2}$ in the $\mathrm{IL}$ containing $\mathrm{TBP}_{-} \mathrm{HNO}_{3}$. In the nitric acid dissolution process, $\mathrm{UO}_{2}$ leads to the 
formation of uranyl ions $\left(\mathrm{UO}_{2}\right)^{2+}$ in the acid solution. In the IL dissolution of $\mathrm{UO}_{2}$ with $\operatorname{TBP}\left(\mathrm{HNO}_{3}\right)_{1.8}\left(\mathrm{H}_{2} \mathrm{O}\right)_{0.6}$, solid $\mathrm{UO}_{2}$ particles results in the formation of some uranyl-nitrate-TBP complex which is extractable by sc- $\mathrm{CO}_{2}$ and identified to be $\mathrm{UO}_{2}\left(\mathrm{NO}_{3}\right)_{2}(\mathrm{TBP})_{2}$. The IL dissolution process described in this paper appears to be faster, with lower activation energy, and produces a readily extractable uranyl complex by $\mathrm{sc}-\mathrm{CO}_{2}$.
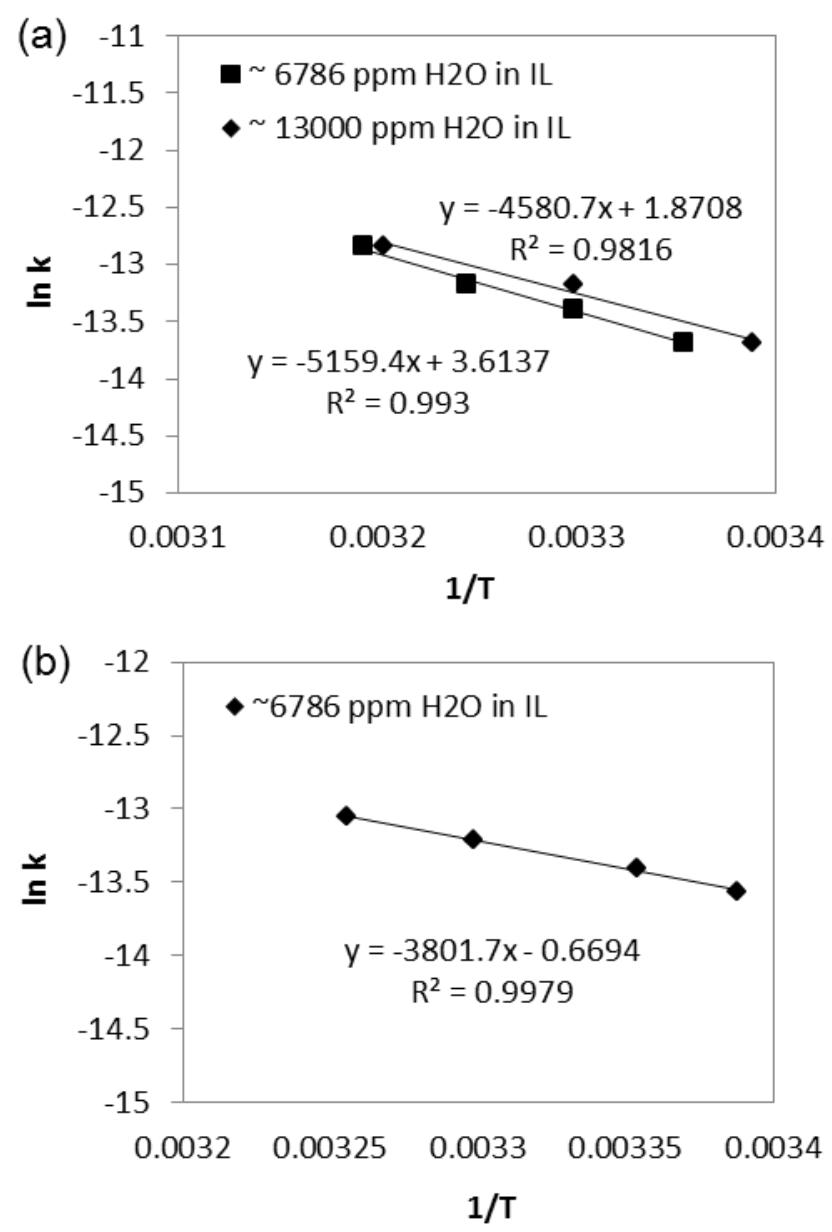

Figure III-6. Plots of $\ln$ k' versus $1 / \mathrm{T}$ (a) for dissolution of $\mathrm{UO}_{2}$ (b) for dissolution of $\mathrm{Nd}_{2} \mathrm{O}_{3}$ in $[\mathrm{Bmim}]\left[\mathrm{Tf}_{2} \mathrm{~N}\right]$ with $\mathrm{TBP}\left(\mathrm{HNO}_{3}\right)_{1.8}\left(\mathrm{H}_{2} \mathrm{O}\right)_{0.6}$

The enthalpy $\left(\Delta \mathrm{H}^{+}\right)$and entropy $\left(\Delta \mathrm{S}^{\ddagger}\right)$ of activation for the IL dissolution processes can be calculated by the following equation

$$
\ln \frac{\mathrm{k}}{\mathrm{T}}=-\frac{\Delta \mathrm{H}^{\ddagger}}{\mathrm{RT}}+\ln \frac{\mathrm{k}_{\mathrm{B}}}{\mathrm{h}}+\frac{\Delta \mathrm{S}^{\ddagger}}{\mathrm{R}}
$$

where $\mathrm{k}$ is reaction rate constant, $\mathrm{T}$ is absolute temperature, $\Delta \mathrm{H}^{\ddagger}$ is enthalpy of activation, $\mathrm{R}$ is the ideal gas constant, $\mathrm{k}_{\mathrm{B}}$ is Boltzmann constant, $\mathrm{h}$ is Planck’s constant, and $\Delta \mathrm{S}^{\ddagger}$ is entropy of 
activation. Plots of $\ln (\mathrm{k} / \mathrm{T})$ versus $(1 / \mathrm{T})$ for dissolution of $\mathrm{UO}_{2}$ and $\mathrm{Nd}_{2} \mathrm{O}_{3}$ are given in Figures III-7a and 7b. The slope and the intercept of each plot are also given in the figures. From these data, we obtain $\Delta \mathrm{H}^{*}$ and $\Delta \mathrm{S}^{*}$ values of $40.4 \pm 4.8 \mathrm{~kJ} \cdot \mathrm{mol}^{-1}$ and $-212.3 \pm 15.7 \mathrm{~J} \cdot \mathrm{mol}^{-1} \cdot \mathrm{K}^{-1}$, respectively, for the dissolution of $\mathrm{UO}_{2}$. Similar calculations for the $\mathrm{Nd}_{2} \mathrm{O}_{3}$ data given in Figure III- $7 \mathrm{~b}$ yield $\Delta \mathrm{H}^{*}$ and $\Delta \mathrm{S}^{\star}$ values of $29.1 \pm 2.9 \mathrm{~kJ} \cdot \mathrm{mol}^{-1}$ and $-258.9 \pm 20.7 \mathrm{~J} \cdot \mathrm{mol}^{-1} \cdot \mathrm{K}^{-1}$, respectively. A more negative $\Delta \mathrm{S}^{\ddagger}$ value for $\mathrm{Nd}_{2} \mathrm{O}_{3}$ dissolution is probably consistent with the structure of the neodymium complex formed in the IL phase relative to that of the uranyl complex. The coordination number of $\mathrm{Nd}^{3+}$ ion $(\mathrm{N}=9)$ is higher than that of $\mathrm{UO}_{2}{ }^{2+}$ ion $(\mathrm{N}=6)$. The higher $\mathrm{N}$ number allows 3 nitrate ions and $3 \mathrm{TBP}$ molecules to be coordinated with $\mathrm{Nd}^{3+}$ in the IL phase.
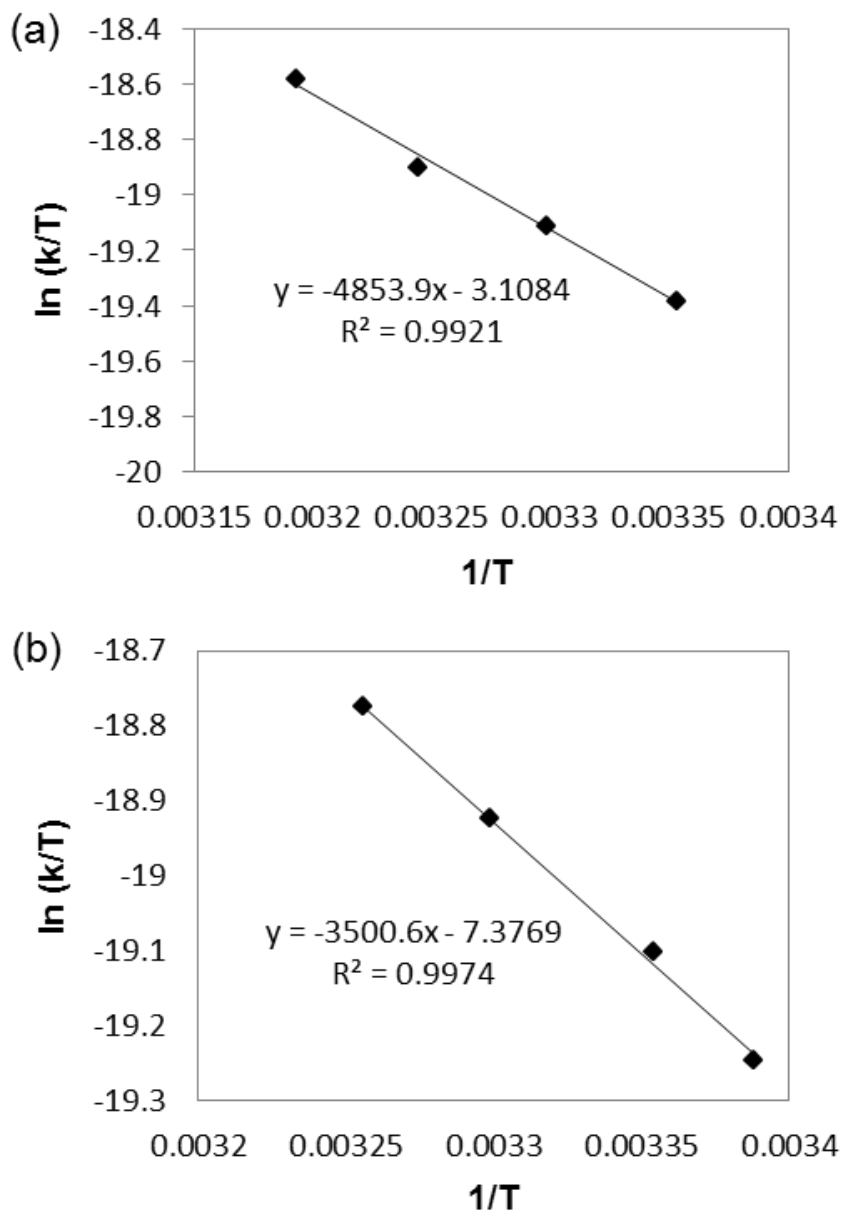

Figure III-7. Plots of $\ln (\mathrm{k} / \mathrm{T})$ versus $1 / \mathrm{T}$ (a) for dissolution of $\mathrm{UO}_{2}$ (b) for dissolution of $\mathrm{Nd}_{2} \mathrm{O}_{3}$ in $[\mathrm{Bmim}]\left[\mathrm{Tf}_{2} \mathrm{~N}\right]$ with $\mathrm{TBP}\left(\mathrm{HNO}_{3}\right)_{1.8}\left(\mathrm{H}_{2} \mathrm{O}\right)_{0.6}$. (Total amount of $\mathrm{H}_{2} \mathrm{O}: 6786 \mathrm{ppm}$ in IL) 


\section{III-3. Viscosity Effect on Dissolution of $\mathrm{UO}_{2}$ in IL with $\mathrm{TBP}\left(\mathrm{HNO}_{3}\right)_{1.8}\left(\mathrm{H}_{2} \mathrm{O}\right)_{0.6}$}

According to a report by Widegren et al., a small amount of water dissolved in $[\mathrm{Bmim}]\left[\mathrm{Tf}_{2} \mathrm{~N}\right]$ can reduce the viscosity of the $\mathrm{IL}^{21}$ Water can be dissolved in $1 \mathrm{~mL}$

$[\mathrm{Bmim}]\left[\mathrm{Tf}_{2} \mathrm{~N}\right]$ up to about $13600 \mathrm{ppm}$ without forming a separate aqueous phase. ${ }^{2,23}$ Based on the result of Karl Fischer titration of our IL system, the total amount of water in $25.2 \mathrm{~mL}$ [Bmim] $\left[\mathrm{Tf}_{2} \mathrm{~N}\right]$ containing TBP $\left(\mathrm{HNO}_{3}\right)_{1.8}\left(\mathrm{H}_{2} \mathrm{O}\right)_{0.6}$ is about $6786 \mathrm{ppm}$. Plot of dissolution rate constant versus total amount of water in the IL containing $\operatorname{TBP}\left(\mathrm{HNO}_{3}\right)_{1.8}\left(\mathrm{H}_{2} \mathrm{O}\right)_{0.6}$ is shown in Figure III- 8 . The dissolution rate constant $\left(1.14 \times 10^{-6} \mathrm{~mol} \cdot \mathrm{cm}^{-2} \cdot \mathrm{min}^{-1}\right)$ at room temperature is slightly increased when 10,000 ppm of water exists in the IL solution. This may be contributed to the decrease in the viscosity of IL. It should be noted that the UV/Vis spectra do not change when $\mathrm{UO}_{2}$ is dissolved in wet IL. The activation energy for wet IL (about $13000 \mathrm{ppm} \mathrm{H}_{2} \mathrm{O}$ ) containing $\operatorname{TBP}\left(\mathrm{HNO}_{3}\right)_{1.8}\left(\mathrm{H}_{2} \mathrm{O}\right)_{0.6}$ is estimated to be about $38.1 \mathrm{~kJ} / \mathrm{mole}$ (shown in Figure III-6a). The activation energy is slightly decreased with decreasing viscosity of IL.

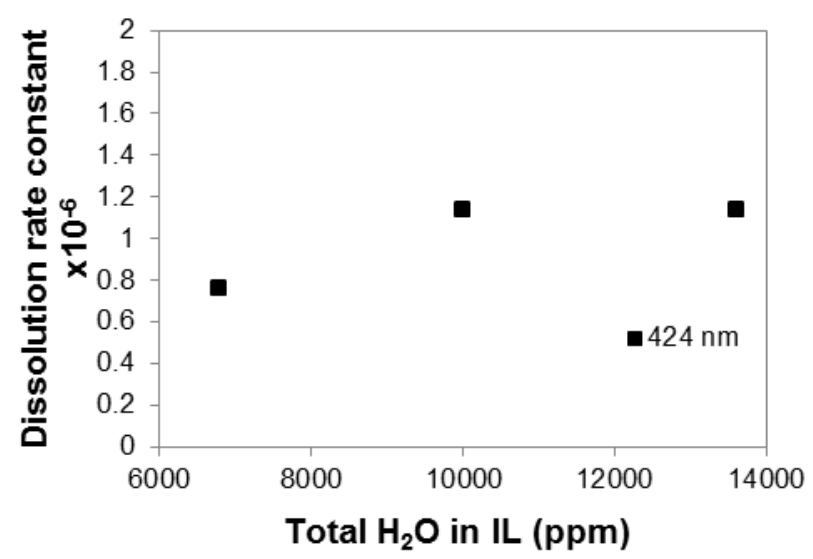

Figure III-8. Plot of dissolution rate constant (at room temperature) versus total amount of water in $\left[\right.$ Bmim] $\left[\mathrm{Tf}_{2} \mathrm{~N}\right]$ containing $\mathrm{TBP}\left(\mathrm{NO}_{3}\right)_{1.8}\left(\mathrm{H}_{2} \mathrm{O}\right)_{0.6}$. The data were monitored at $424 \mathrm{~nm}$.

\section{III-4. Summary}

Dissolution behaviors of $\mathrm{UO}_{2}$ and $\mathrm{Nd}_{2} \mathrm{O}_{3}$ in the IL $[\mathrm{Bmim}]\left[\mathrm{Tf}_{2} \mathrm{~N}\right]$ with $\operatorname{TBP}\left(\mathrm{HNO}_{3}\right)_{1.8}\left(\mathrm{H}_{2} \mathrm{O}\right)_{0.6}$ have been studied. All dissolutions are carried out under rapid stirring in order to ignore the diffusion effect and the dissolution results are analyzed based on the assumptions that the $\mathrm{UO}_{2}$ and $\mathrm{Nd}_{2} \mathrm{O}_{3}$ particle are spherical and homogeneously dissolved in the IL. The dissolution rate constants are estimated to be about $8.13 \times 10^{-7}$ and $1.29 \times 10^{-6} \mathrm{~mol} \cdot \mathrm{cm}^{-2}$. $\min ^{-1}$ for dissolution of $\mathrm{UO}_{2}$ and $\mathrm{Nd}_{2} \mathrm{O}_{3}$, respectively, at room temperature. The dissolution rate constant increases with increasing temperature or decreasing viscosity of the IL. The activation 
energies for $\mathrm{UO}_{2}$ and $\mathrm{Nd}_{2} \mathrm{O}_{3}$ dissolution are approximately $46.3 \pm 4.8$ and $31.6 \pm 3.2 \mathrm{~kJ} \cdot \mathrm{mol}^{-1}$, respectively. Both activation energy $(\mathrm{Ea})$ and enthalpy $\left(\Delta \mathrm{H}^{\ddagger}\right)$ of activation of $\mathrm{Nd}_{2} \mathrm{O}_{3}$ are lower than that of $\mathrm{UO}_{2}$, indicating a faster dissolution rate for $\mathrm{Nd}_{2} \mathrm{O}_{3}$. The activation energy for dissolution of $\mathrm{UO}_{2}$ decreases slightly when the amount of water in the IL system increases (viscosity of IL is reduced). An important observation is that the dissolution rate constant of $\mathrm{UO}_{2}$ in the IL with $\mathrm{TBP}\left(\mathrm{HNO}_{3}\right)_{1.8}\left(\mathrm{H}_{2} \mathrm{O}\right)_{0.6}$ is about a factor of 2 faster than that reported for its dissolution in $8 \mathrm{M}$ nitric acid. 


\section{Chapter IV. Separation of $\mathrm{UO}_{2}\left(\mathrm{NO}_{3}\right)_{2}(\mathrm{TBP})_{2}$ and $\mathrm{Nd}\left(\mathrm{NO}_{3}\right)_{3}(\mathrm{TBP})_{3}$ in Ionic Liquid Using Diglycolamide and Supercritical $\mathrm{CO}_{2}$ Extraction}

Liquid-liquid extraction of lanthanides from aqueous solutions into ionic liquids using $\mathrm{N}, \mathrm{N}, \mathrm{N}^{\prime}, \mathrm{N}^{\prime}$-tetra(n-octyl)diglycolamide (TODGA) as an extractant is known in the literature. ${ }^{24}$ The extracted lanthanide species in the IL phase showed a molar ratio of TODGA to lanthanide $\left(\mathrm{La}^{3+}, \mathrm{Eu}^{3+}\right.$, or $\left.\mathrm{Lu}^{3+}\right)$ determined by slope analysis to be $3: 1{ }^{24}$ Extraction of uranyl ion from the aqueous phase into $\left[\mathrm{C}_{\mathrm{n}} \mathrm{mim}\right]\left[\mathrm{PF}_{6}\right](\mathrm{n}=4,6$, and 8$)$ using $\mathrm{N}, \mathrm{N}, \mathrm{N}$ 'N'-tetrabutyldiglycolamide (TBDGA) as an extractant was also investigated and the complex was found to have a ratio of

TBDGA : $\mathrm{UO}_{2}{ }^{2+}=2: 1{ }^{25}$ The mechanism of these aqueous-IL extractions has been suggested to involve cation-exchange. ${ }^{24,25}$ Extraction of lanthanides and actinides by sc- $\mathrm{CO}_{2}$ is well known in the literature. ${ }^{1}$ Using a TBP- $\mathrm{HNO}_{3}$ complex such as $\mathrm{TBP}\left(\mathrm{HNO}_{3}\right)_{1.8}\left(\mathrm{H}_{2} \mathrm{O}\right)_{0.6}$ as an extractant, uranium dioxide $\left(\mathrm{UO}_{2}\right)$ and lanthanide sesquioxides $\left(\mathrm{Ln}_{2} \mathrm{O}_{3}\right)$ can be dissolved directly in sc- $\mathrm{CO}_{2}$ forming $\mathrm{CO}_{2}$-soluble $\mathrm{UO}_{2}\left(\mathrm{NO}_{3}\right)_{2}(\mathrm{TBP})_{2}$ and $\mathrm{Ln}\left(\mathrm{NO}_{3}\right)_{3}(\mathrm{TBP})_{3}$, respectively. The solubility of $\mathrm{UO}_{2}\left(\mathrm{NO}_{3}\right)_{2}(\mathrm{TBP})_{2}$ in sc- $\mathrm{CO}_{2}$ at different temperatures and pressures has been carefully measured. The solubility of $\mathrm{Ln}\left(\mathrm{NO}_{3}\right)_{3}(\mathrm{TBP})_{3}$ in sc- $\mathrm{CO}_{2}$ is not known. In a recent report, Tian et al. has shown that TBDGA complexes of lanthanides and uranyl are not soluble in sc- $\mathrm{CO}_{2}$ without a polar modifier. ${ }^{26}$

The purpose of this study is to understand the coordination of uranyl and neodymium with TBDGA (Scheme IV-1) in a single IL phase and to test the feasibility of separating uranium and neodymium species from the IL phase by $\mathrm{sc}-\mathrm{CO}_{2}$ extraction. Complexation of TBDGA with $\mathrm{UO}_{2}{ }^{2+}$ and $\mathrm{Nd}^{3+}$ in the IL [Bmim] $\left[\mathrm{Tf}_{2} \mathrm{~N}\right]$ was studied using IR and Raman spectroscopy. To better control the amount of water in the IL, we used $\mathrm{UO}_{2}\left(\mathrm{Tf}_{2} \mathrm{~N}\right)_{2} \bullet 3 \mathrm{H}_{2} \mathrm{O}, \mathrm{Nd}\left(\mathrm{Tf}_{2} \mathrm{~N}\right)_{3} \bullet 2 \mathrm{H}_{2} \mathrm{O}$, and TBAN (tetrabutylammonium nitrate) as the starting materials for spectroscopic measurements. The solubility, distribution ratio and separation factor of $\mathrm{UO}_{2}\left(\mathrm{NO}_{3}\right)_{2}(\mathrm{TBP})_{2}$ and $\mathrm{Nd}\left(\mathrm{NO}_{3}\right)_{3}(\mathrm{TBP})_{3}$ in sc- $\mathrm{CO}_{2}$ were determined using a high pressure fiber-optic cell connected to a CCD array UVVis spectrometer.

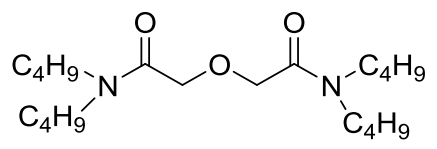

Scheme IV-1. Structure of TBDGA 


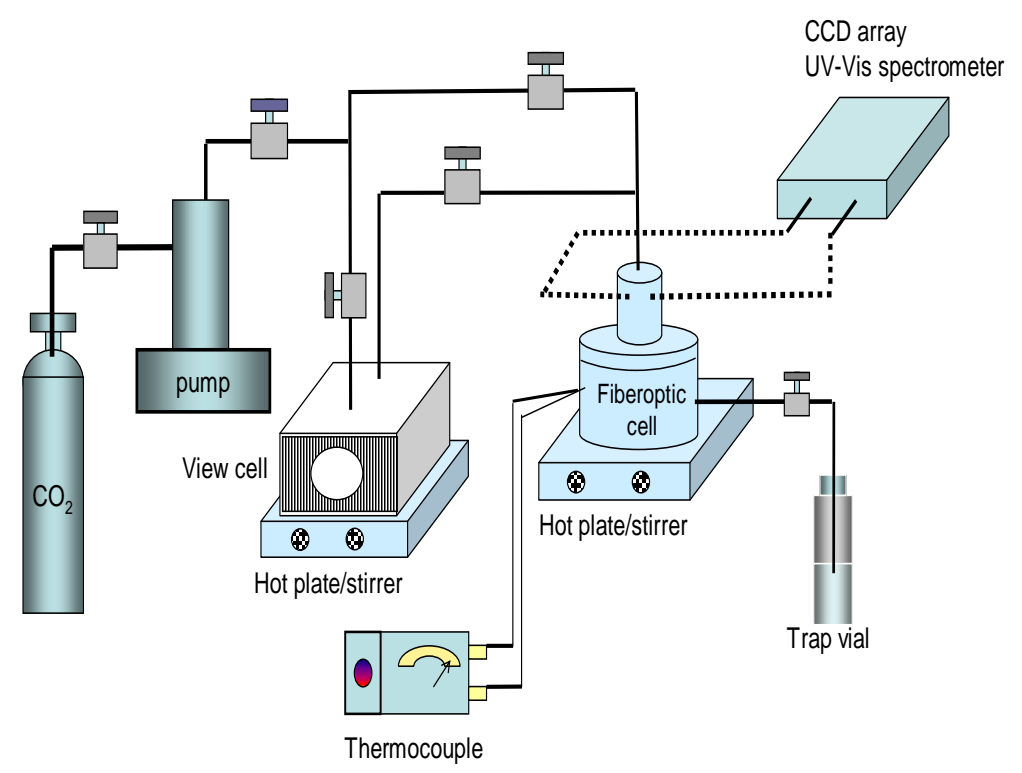

Figure IV-1. Schematic diagram of the supercritical fluid extraction system for dissolution and solubility measurements. The system is equipped with a view-cell for visual observation and a fiber-optic cell connected to a CCD array UV-Vis spectrometer for rapid spectroscopic measurements.

\section{IV-1. Complexation of Uranyl with TBDGA in Ionic Liquid}

Figure IV-1 shows the vibrational stretching modes of $(\mathrm{O}=\mathrm{U}=\mathrm{O})^{2+}$ acquired from solutions containing $0.1 \mathrm{M} \mathrm{UO}_{2}\left(\mathrm{Tf}_{2} \mathrm{~N}\right)_{2} \cdot 3 \mathrm{H}_{2} \mathrm{O}$ in the IL to which increments of TBDGA were added (from $0.05 \mathrm{M}$ to $0.3 \mathrm{M}$ ). The vibrational peaks at 841 , and $950 \mathrm{~cm}^{-1}$ in the IR spectra (Figure IV-1A) and at 825, 884, 908, 948, and $975 \mathrm{~cm}^{-1}$ in the Raman spectra (Figure IV-1B) all arise from the IL $[\mathrm{Bmim}]\left[\mathrm{Tf}_{2} \mathrm{~N}\right]$. The asymmetric stretching $\mathrm{v}_{\mathrm{as}}\left(\mathrm{UO}_{2}\right)$ mode appears in the infrared spectra (Figure IV-1A) and increases in the range $968-948 \mathrm{~cm}^{-1}$ with increasing concentrations of TBDGA. When the concentration of TBDGA reaches $0.2 \mathrm{M}$, the $v_{\text {as }}\left(\mathrm{UO}_{2}\right)$ mode appears at $948 \mathrm{~cm}^{-1}$ and does not change with further increase in TBDGA concentration, indicating that the uranyl-TBDGA complex formed may have a molar ratio of TBDGA: $\mathrm{UO}_{2}{ }^{2+}=$ 2:1. The bonded $\mathrm{C}=\mathrm{O}$ groups of TBDGA appear as a broad peak between $1640-1590 \mathrm{~cm}^{-1}$ with a small peak at $1514 \mathrm{~cm}^{-1}(\mathrm{vC}-\mathrm{N})$ in the IR spectra, suggesting that TBDGA is coordinated to $\mathrm{UO}_{2}{ }^{2+}$ (Figure IV-1C). The free $\mathrm{C}=\mathrm{O}$ group of TBDGA can be detected at about $1647 \mathrm{~cm}^{-1}$ in the IR spectra when 0.3 M TBDGA is added in the IL solution (Figure IV-1C-e). In the Raman spectra (Figure IV-1B), similar results are observed, i.e. the symmetric stretching mode $v_{\mathrm{s}}\left(\mathrm{UO}_{2}\right)$ 
shifts from $884 \mathrm{~cm}^{-1}$ in the absence of TBDGA to a limiting value of $864 \mathrm{~cm}^{-1}$ when the molar ratio of $\mathrm{UO}_{2}{ }^{2+}$ : TBDGA $=1: 2$. These results are consistent with that found in the liquid-liquid extraction of uranyl species from nitric acid to IL phase with TBDGA. ${ }^{25}$
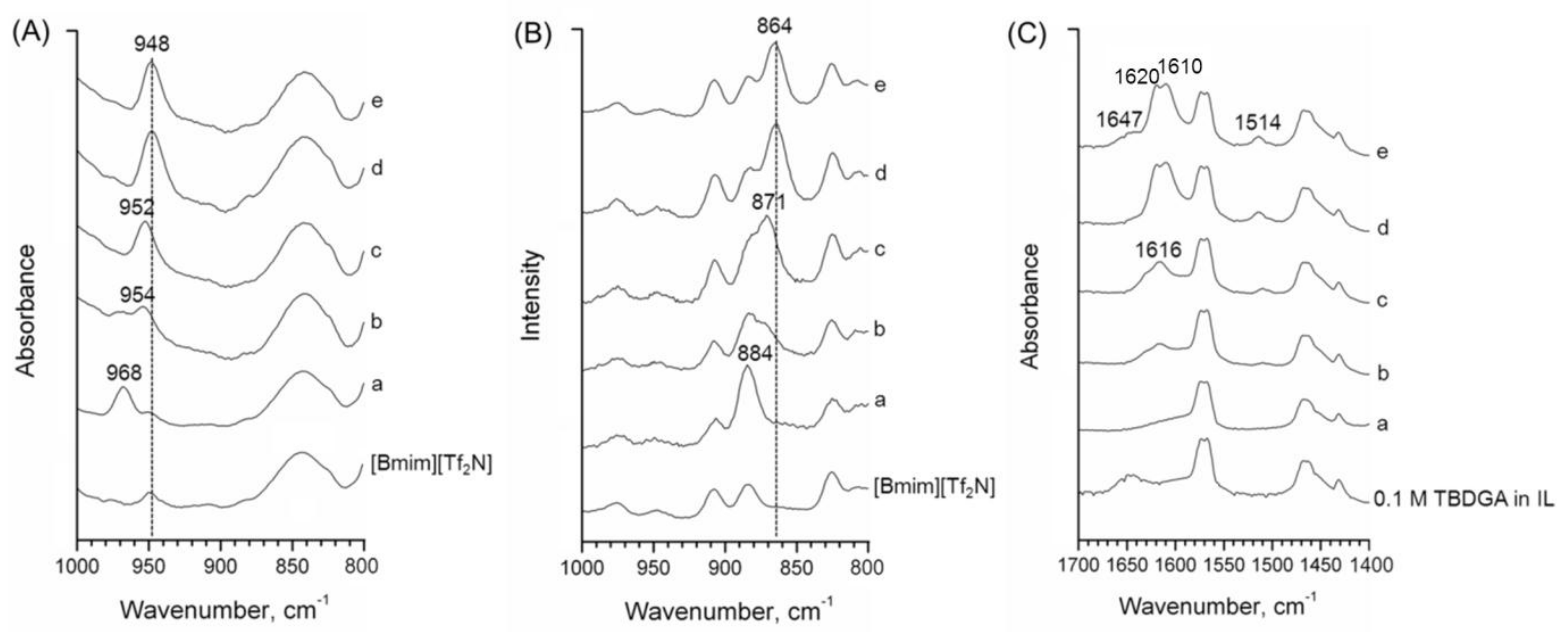

Figure IV-2. (A) ATR-FTIR spectra of the $v_{\mathrm{as}}\left(\mathrm{UO}_{2}\right)$ region, (B) Raman spectra of the $v_{\mathrm{s}}\left(\mathrm{UO}_{2}\right)$ region, and $(\mathbf{C})$ ATR-FTIR spectra of the $v(C=O)$ region for solutions of [Bmim] $\left[\mathrm{Tf}_{2} \mathrm{~N}\right.$ ] containing different molar ratio of $\mathrm{UO}_{2}{ }^{2+}$ to TBDGA (a) $0.1 \mathrm{M} \mathrm{UO}_{2}\left(\mathrm{Tf}_{2} \mathrm{~N}\right)_{2} \cdot 3 \mathrm{H}_{2} \mathrm{O}$ only, (b) 1: 0.5 , (c) $1: 1$, (d) $1: 2$, and (e) 1: 3 .

The $v_{\mathrm{as}}\left(\mathrm{UO}_{2}\right)$ mode $\left(948 \mathrm{~cm}^{-1}\right)$ and the $v_{\mathrm{s}}\left(\mathrm{UO}_{2}\right)$ mode $\left(864 \mathrm{~cm}^{-1}\right)$ of $\mathrm{UO}_{2}(\mathrm{TBDGA})_{2}{ }^{2+}$ shown in Figures IV-1A-d and IV-1B-d have lower frequencies compared to those reported for $\mathrm{UO}_{2}\left(\mathrm{NO}_{3}\right)_{2}$ in the IL (i.e. $v_{\mathrm{as}}\left(\mathrm{UO}_{2}\right)$ at $951 \mathrm{~cm}^{-1}$ and $v_{\mathrm{s}}\left(\mathrm{UO}_{2}\right)$ at $\left.869 \mathrm{~cm}^{-1}\right){ }^{27}$ The lower $v_{\mathrm{as}}\left(\mathrm{UO}_{2}\right)$ and $v_{\mathrm{s}}\left(\mathrm{UO}_{2}\right)$ observed in $\mathrm{UO}_{2}(\mathrm{TBDGA})_{2}{ }^{2+}$ may indicate that bonding of uranyl to TBDGA is stronger than that to nitrate ion. Once $0.2 \mathrm{M}$ of TBDGA is dissolved in $0.1 \mathrm{M}$ uranyl in $[\mathrm{Bmim}]\left[\mathrm{Tf}_{2} \mathrm{~N}\right]$, addition of nitrate $(\mathrm{TBAN})$ cannot change $v_{\text {as }}\left(\mathrm{UO}_{2}\right)$ in the IR spectra, indicating that nitrate ion is not able to displace TBDGA bonded to uranyl in the IL. Also, both $v_{\mathrm{as}}\left(\mathrm{UO}_{2}\right)$ and $v_{\mathrm{s}}\left(\mathrm{UO}_{2}\right)$ are not affected by adding TBP to the IL solution once the complex $\mathrm{UO}_{2}(\mathrm{TBDGA})_{2}{ }^{2+}$ is formed. The IR and Raman results appear to indicate that TBDGA is a stronger ligand for uranyl than for both nitrate and TBP.

As the TBDGA concentration is increased from $0.05 \mathrm{M}$ to $0.1 \mathrm{M}$ in the IL solution containing 0.1 $\mathrm{M} \mathrm{UO}_{2}\left(\mathrm{Tf}_{2} \mathrm{~N}\right)_{2} \cdot 3 \mathrm{H}_{2} \mathrm{O}$ and 0.2 M TBAN, the $v_{\text {as }}\left(\mathrm{UO}_{2}\right)$ shifts from $945 \mathrm{~cm}^{-1}$ to 942 $\mathrm{cm}^{-1}$ in the infrared spectra (Figure IV-2A-a and -b) and $v_{\mathrm{s}}\left(\mathrm{UO}_{2}\right)$ shifts from $865 \mathrm{~cm}^{-1}$ to 861 
$\mathrm{cm}^{-1}$ in the Raman spectra (Figure IV-2B-a and -b). While the concentration of TBDGA is increased to $0.2 \mathrm{M}$, the vibrational modes of uranyl(VI) in the infrared (Figure IV-2A-c) and in the Raman (Figure IV-2B-c) spectra shift to higher frequency at $948 \mathrm{~cm}^{-1}$ and $864 \mathrm{~cm}^{-1}$, respectively. It should be noted that a small peak at about $880 \mathrm{~cm}^{-1}$ may relate to the vibrational mode of TBAN in IL shown in Figure 2A. The bonded nitrate at $1536 \mathrm{~cm}^{-1}$ disappears and a peak at $1514 \mathrm{~cm}^{-1}(v \mathrm{C}-\mathrm{N})$ appears in the IR spectra simultaneously (Figure IV-2C-c). These results suggest that TBDGA may replace nitrate ions coordinated to each mole of uranyl, resulting in the same vibrational peaks as those shown in Figure IV-1A-d, Figure IV-1B-d, and Figure IV-1C-d.
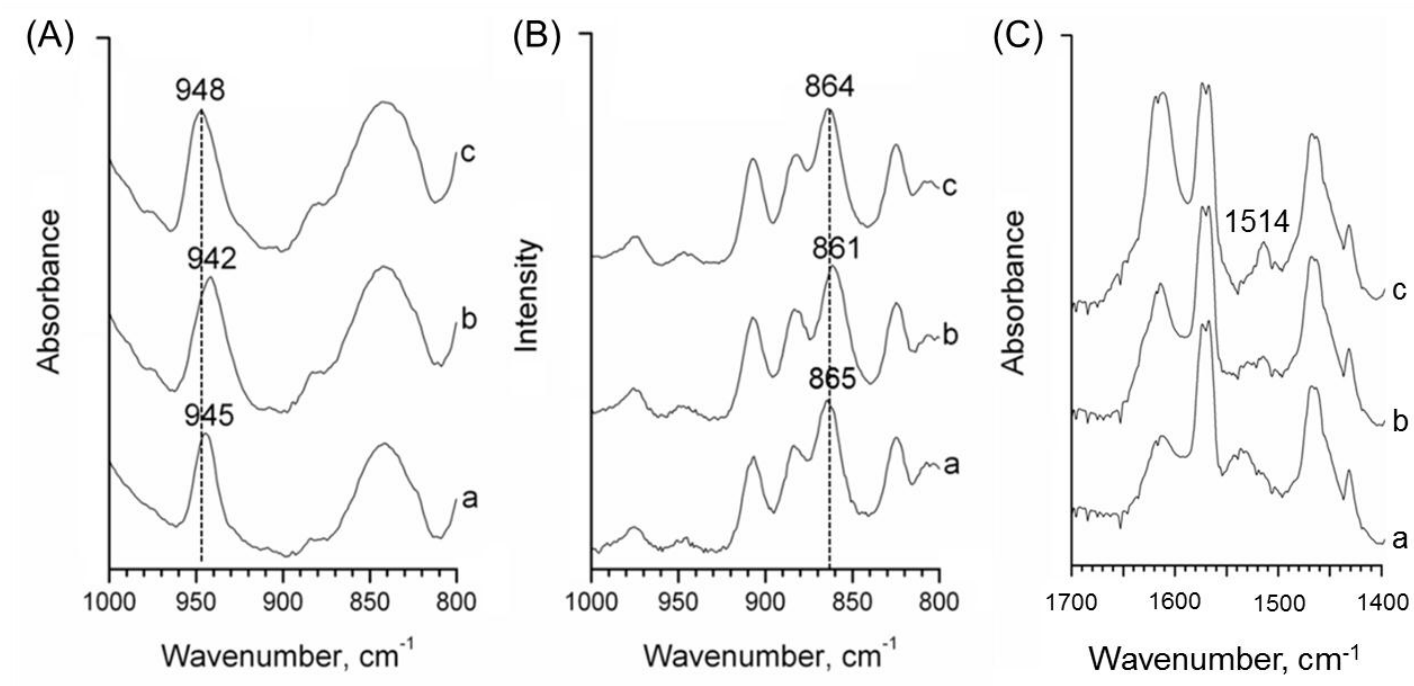

Figure IV-3. (A) ATR-FTIR spectra of the $v_{\mathrm{as}}\left(\mathrm{UO}_{2}\right)$ region, (B) Raman spectra of the $v_{\mathrm{s}}\left(\mathrm{UO}_{2}\right)$ region, and $(\mathbf{C})$ ATR-FTIR spectra of the $v(\mathrm{C}=\mathrm{O})$ and $v(\mathrm{NO})$ region for solutions of $[\mathrm{Bmim}]\left[\mathrm{Tf}_{2} \mathrm{~N}\right]$ containing different molar ratio of $\mathrm{UO}_{2}{ }^{2+}$ : TBDGA: TBAN (a) 1: $0.5: 2$, (b) 1: 1 : 2 , and (c) $1: 2: 2$.

In Figure IV-4, 0.1 $\mathrm{M} \mathrm{UO}_{2}\left(\mathrm{Tf}_{2} \mathrm{~N}\right)_{2} \cdot 3 \mathrm{H}_{2} \mathrm{O}$ and $0.1 \mathrm{M}$ TBDGA are dissolved in the IL to which increments of TBAN are added from $0.05 \mathrm{M}$ to $0.3 \mathrm{M}$. The asymmetric stretching mode of uranyl appears at $952 \mathrm{~cm}^{-1}$ in the infrared spectra and the symmetric stretching mode of uranyl lies at $871 \mathrm{~cm}^{-1}$ in the Raman spectra. As the concentration of TBAN is increased to $0.2 \mathrm{M}$ or more, the $v_{\mathrm{as}}\left(\mathrm{UO}_{2}\right)$ band stops at $942 \mathrm{~cm}^{-1}$ in the infrared spectra (Figure IV-3A-d ) and $v_{\mathrm{s}}\left(\mathrm{UO}_{2}\right)$ mode shifts to $861 \mathrm{~cm}^{-1}$ in the Raman spectra (Figure IV-3B-d ). These results suggest that 2 moles of nitrate and one mole of TBDGA may be coordinated with one mole of uranyl in the IL, forming a neutral $\mathrm{UO}_{2}\left(\mathrm{NO}_{3}\right)_{2}$ (TBDGA) complex, which is the same as that found in Figure IV- 
2A-b and Figure IV-2B-b. The vibrational modes of O-N-O of bonded nitrate and C-N of bonded TBDGA overlap in the range between 1500 and $1540 \mathrm{~cm}^{-1}$ shown in Figure IV-3C. The crystal structure of $\mathrm{UO}_{2}\left(\mathrm{NO}_{3}\right)_{2}(\mathrm{TBDGA})$ has been analyzed by X-ray diffraction and its $\mathrm{v}_{\mathrm{as}}\left(\mathrm{UO}_{2}\right)$ vibrational mode at $942 \mathrm{~cm}^{-1}$ in IR has also been reported in the literature. ${ }^{28}$
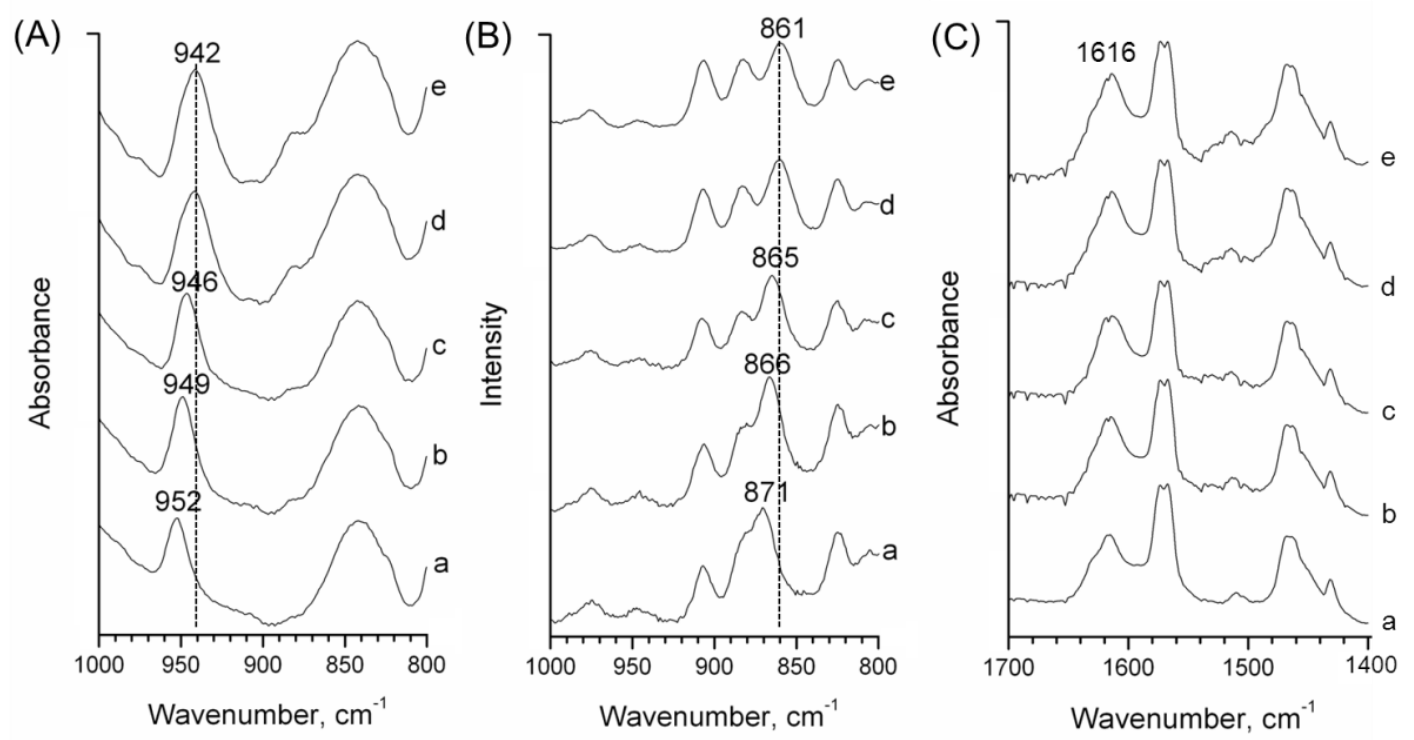

Figure IV-4. (A) ATR-FTIR spectra of the $v_{\mathrm{as}}\left(\mathrm{UO}_{2}\right)$ region, (B) Raman spectra of the $v_{\mathrm{s}}\left(\mathrm{UO}_{2}\right)$ region, and $(\mathbf{C})$ ATR-FTIR spectra of the $v(\mathrm{C}=\mathrm{O})$ and $v(\mathrm{NO})$ region for solutions of $[\mathrm{Bmim}]\left[\mathrm{Tf}_{2} \mathrm{~N}\right]$ containing different molar ratio of $\mathrm{UO}_{2}{ }^{2+}$ : TBDGA: TBAN (a) 1: 1: 0, (b) 1: 1: 0.5, (c) $1: 1: 1$, (d) $1: 1: 2$, and (e) $1: 1: 3$.

The $v_{\mathrm{as}}\left(\mathrm{UO}_{2}\right)$ and $v_{\mathrm{s}}\left(\mathrm{UO}_{2}\right)$ modes of uranyl appear at $941 \mathrm{~cm}^{-1}$ and $860 \mathrm{~cm}^{-1}$, respectively, when the IL contains $0.1 \mathrm{M} \mathrm{UO}_{2}\left(\mathrm{Tf}_{2} \mathrm{~N}\right)_{2}, 0.2 \mathrm{M}$ TBP and $0.2 \mathrm{M}$ TBAN. When $0.1 \mathrm{M}$ TBDGA is added to the IL, the vibrational modes of uranyl shift slightly from $941 \mathrm{~cm}^{-1}$ to $942 \mathrm{~cm}^{-1}$ in the IR (Figure IV-4A-a) and from $860 \mathrm{~cm}^{-1}$ to $861 \mathrm{~cm}^{-1}$ in the Raman spectra (Figure IV-4B-a). As 0.2 $M$ or more of TBDGA is added to the IL solution, the $v_{\text {as }}\left(U_{2}\right)$ mode appears fixed at $948 \mathrm{~cm}^{-1}$ in the infrared spectra (Figure IV-4A-b and -c). Moreover, the $v_{\mathrm{s}}\left(\mathrm{UO}_{2}\right)$ mode also stops at 864 $\mathrm{cm}^{-1}$ in the Raman spectra (Figure IV-4B-b and -c). It is known that the $v(\mathrm{NO})$ mode of nitrate appears at $1523 \mathrm{~cm}^{-1}$ when $0.1 \mathrm{M} \mathrm{UO}_{2}\left(\mathrm{Tf}_{2} \mathrm{~N}\right)_{2}, 0.2 \mathrm{M}$ TBP and $0.2 \mathrm{M}$ TBAN are dissolved in the IL. The bonded nitrate at $1523 \mathrm{~cm}^{-1}$ becomes unclear and a $v(\mathrm{C}-\mathrm{N})$ peak of bonded TBDGA at $1514 \mathrm{~cm}^{-1}$ appears when TBDGA is added in the IL (Figure IV-4C-b and -c). A small peak at about $880 \mathrm{~cm}^{-1}$ may be related to the vibrational peaks of TBAN in IL and a broad peak at about $913 \mathrm{~cm}^{-1}$ may be related to the $v(\mathrm{C}-\mathrm{C})$ mode of TBP shown in Figure IV-4A. The results shown 
here are consistent with those given in Figure IV-1A-d and Figure IV-1B-d, i.e. both $\mathrm{NO}_{3}{ }^{-}$and TBP ligands coordinated to uranyl can be replaced by TBDGA to form $\mathrm{UO}_{2}(\mathrm{TBDGA})_{2}{ }^{2+}$ in the IL. It should be noted that the free nitrate and TBP in this experiment are difficult to detect probably because the vibrational modes of $\mathrm{O}-\mathrm{N}-\mathrm{O}$ of free nitrate and $\mathrm{P}=\mathrm{O}$ of free TBP overlap with the vibrational peaks of the IL.
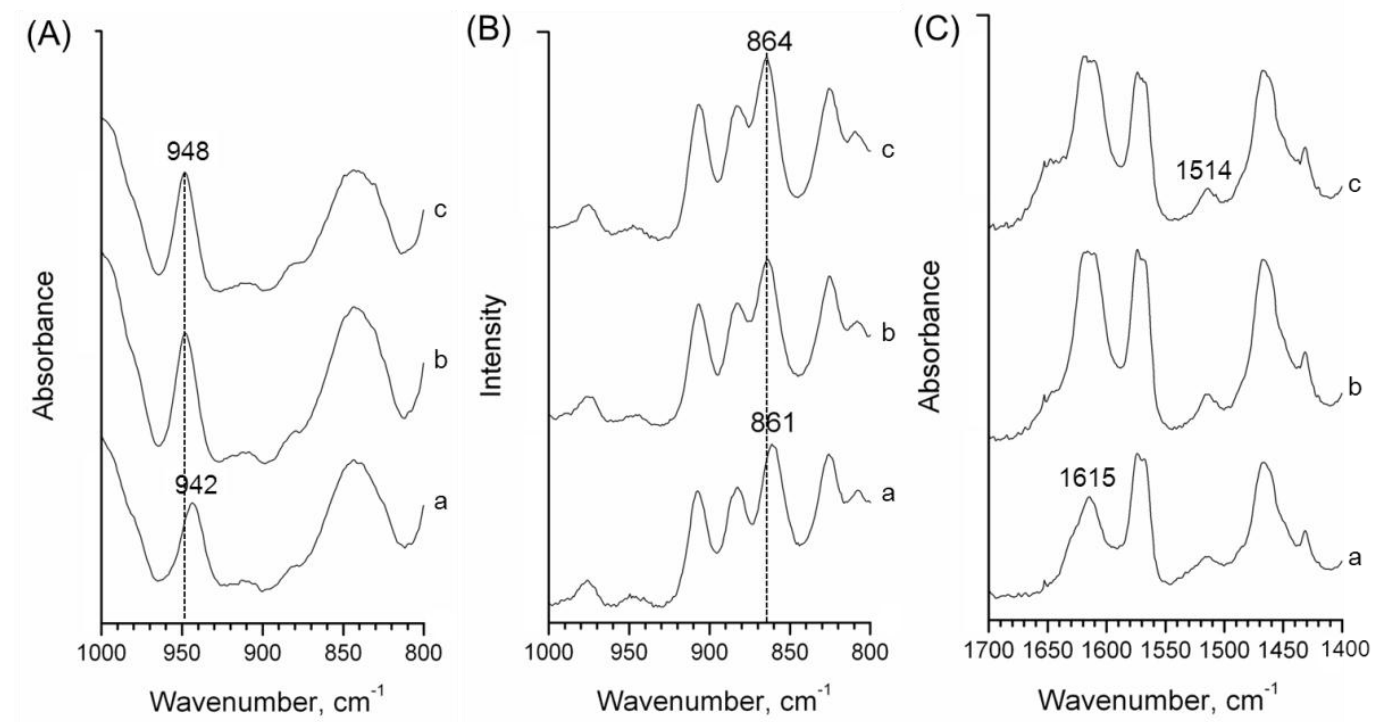

Figure IV-5. (A) ATR-FTIR spectra of the $v_{\mathrm{as}}\left(\mathrm{UO}_{2}\right)$ region and (B) Raman spectra of the $v_{\mathrm{s}}\left(\mathrm{UO}_{2}\right)$ region for solutions of $[\mathrm{Bmim}]\left[\mathrm{Tf}_{2} \mathrm{~N}\right]$ containing different molar ratio of $\mathrm{UO}_{2}{ }^{2+}$ : TBDGA: TBAN: TBP (a) 1:1:2:2, (b) 1:2:2:2, (c) $1: 3: 2: 2$.

\section{IV-2. Complexation of Neodymium(III) with TBDGA in Ionic Liquid}

Trivalent neodymium ion $\left(\mathrm{Nd}^{3+}\right)$ does not have vibrational modes like uranyl. The vibrational mode of $\mathrm{C}=\mathrm{O}$ functional groups of TBDGA ligand may be used to evaluate the coordination of $\mathrm{Nd}^{3+}$ ion with TBDGA in the IR spectra. The vibrational peaks at 1432, 1468, and around $1570 \mathrm{~cm}^{-1}$ all arise from the IL $[\mathrm{Bmim}]\left[\mathrm{Tf}_{2} \mathrm{~N}\right]$ in the IR spectra (Figure IV-6-a). The vibrational peak for the two free $\mathrm{C}=\mathrm{O}$ groups of TBDGA appears at $1647 \mathrm{~cm}^{-1}$ in the IR spectrum (Figure IV-6-b). Figure IV-5-c to -f show the IR spectra when $0.1 \mathrm{M} \mathrm{Nd}\left(\mathrm{Tf}_{2} \mathrm{~N}\right)_{3} \cdot 2 \mathrm{H}_{2} \mathrm{O}$ is dissolved in $[\mathrm{Bmim}]\left[\mathrm{Tf}_{2} \mathrm{~N}\right]$ containing different concentration of TBDGA from $0.1 \mathrm{M}$ to $0.4 \mathrm{M}$. When the $\mathrm{C}=\mathrm{O}$ groups of TBDGA are coordinated to the neodymium(III) ion, the vibrational peak of bonded $\mathrm{C}=\mathrm{O}$ groups appears at $1613 \mathrm{~cm}^{-1}$ and a small peak at $1512 \mathrm{~cm}^{-1}(\mathrm{vC}-\mathrm{N})$ also appears in the IR spectra (Figure IV-6-c to -f). The intensity of the peak at $1613 \mathrm{~cm}^{-1}$ increases gradually when different concentration of TBDGA is added (Figure IV-6-c to -e). As the 
concentration of TBDGA is greater than $0.3 \mathrm{M}$ (Figure IV-5-f), the vibrational peak of unbound $\mathrm{C}=\mathrm{O}$ groups appears at $1647 \mathrm{~cm}^{-1}$ in the IR spectra (Figure IV-6-f). These results illustrate that 3 moles of TBDGA are likely coordinated with each mole of $\mathrm{Nd}^{3+}$.

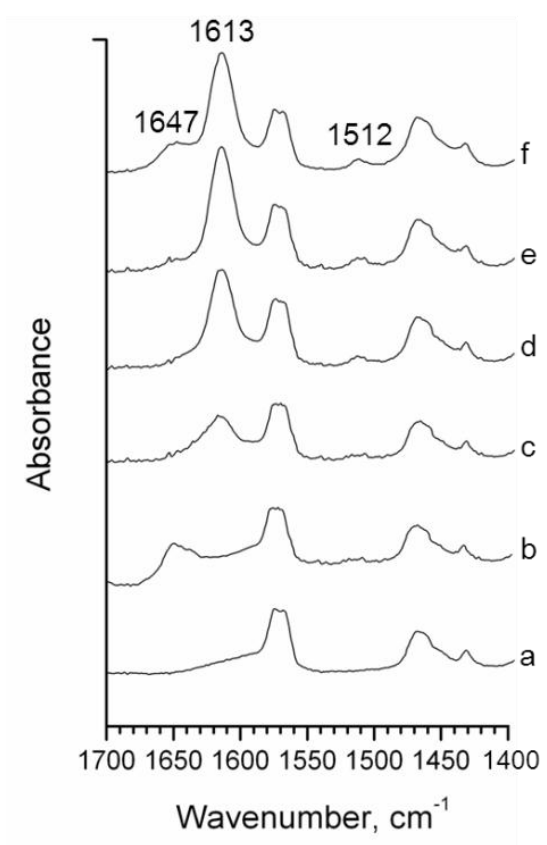

Figure IV-6. ATR-FTIR spectra of the $\mathrm{C}=\mathrm{O}$ region for solutions of $[\mathrm{Bmim}]\left[\mathrm{Tf}_{2} \mathrm{~N}\right]$ containing different molar ratio of $\mathrm{Nd}^{3+}$ : TBDGA (a) [Bmim] $\left[\mathrm{Tf}_{2} \mathrm{~N}\right]$ only, (b) $0.1 \mathrm{M}$ TBDGA in $[\mathrm{Bmim}]\left[\mathrm{Tf}_{2} \mathrm{~N}\right]$ (c) 1: 1, (d) 1:2, (e) 1: 3, and (f) 1:4.

The IR spectra of $0.1 \mathrm{M} \mathrm{Nd}\left(\mathrm{Tf}_{2} \mathrm{~N}\right)_{3} \cdot 2 \mathrm{H}_{2} \mathrm{O}$ in $[\mathrm{Bmim}]\left[\mathrm{Tf}_{2} \mathrm{~N}\right]$ with different amounts of TBAN and TBP are shown in Figure IV-7. It was reported that $\mathrm{Nd}^{3+}$ in nitric acid solutions could be extracted into organic solvents with TBP, forming a neutral $\mathrm{Nd}\left(\mathrm{NO}_{3}\right)_{3}(\mathrm{TBP})_{3}$ complex. $^{29}$ The IR spectrum of the mixture with molar ratio of $\mathrm{Nd}\left(\mathrm{Tf}_{2} \mathrm{~N}\right)_{3} \cdot 2 \mathrm{H}_{2} \mathrm{O}: \mathrm{TBAN}$ : TBP $=1: 3: 3$ dissolved in $[\mathrm{Bmim}]\left[\mathrm{Tf}_{2} \mathrm{~N}\right]$ is shown in Figure IV-7-c. A shoulder in the range between 1480-1530 $\mathrm{cm}^{-1}$ in the IR spectra (Figure IV-7-b and -c) can be assigned to the $v_{\mathrm{as}}(\mathrm{NO})$ mode of nitrate bonded to $\mathrm{Nd}^{3+}$ ion. The UV/Vis spectrum of the IL solution containing the molar ratio of $\mathrm{Nd}\left(\mathrm{Tf}_{2} \mathrm{~N}\right)_{3} \cdot 2 \mathrm{H}_{2} \mathrm{O}: \mathrm{TBAN}: \mathrm{TBP}=1: 3: 3$ shows the same $\mathrm{UV} / \mathrm{Vis}$ spectrum as that found in hexane (Figure IV-8), comfirming the presence of $\mathrm{Nd}\left(\mathrm{NO}_{3}\right)_{3}(\mathrm{TBP})_{3}$ in the IL phase. When $0.3 \mathrm{M}$ TBDGA is added in the IL solution containing $0.1 \mathrm{M} \mathrm{Nd}\left(\mathrm{Tf}_{2} \mathrm{~N}\right)_{3} \cdot 2 \mathrm{H}_{2} \mathrm{O}, 0.3 \mathrm{M}$ TBP and $0.3 \mathrm{M}$ TBAN, the bonded nitrate peak disappears and the bonded $\mathrm{C}=\mathrm{O}$ peak appears simultaneously at $1613 \mathrm{~cm}^{-1}$ and at $1512 \mathrm{~cm}^{-1}$ (Figure IV-7-d), which is the same as that shown in Figure IV-6-e. These results suggest that TBDGA ligand can replace both nitrate and TBP 
ligands in $\mathrm{Nd}\left(\mathrm{NO}_{3}\right)_{3}(\mathrm{TBP})_{3}$ complex, forming a $\mathrm{Nd}(\mathrm{TBDGA})_{3}{ }^{3+}$ complex in the IL. Comparing this result to the liqiud-liquid extraction using TODGA as an extractant to extract lanthanide ions from nitric acid solution into IL phase, ${ }^{24}$ the same conclusion can be made, i.e. the molar ratio of trivalent lanthanide ion to TBDGA is $1: 3$. The overall IR and Raman results indicate that vibrational spectroscopy is a uesful tool to investigate the coordination of $\left(\mathrm{UO}_{2}\right)^{2+}$ and $\mathrm{Nd}^{3+}$ with TBDGA in a single IL phase.

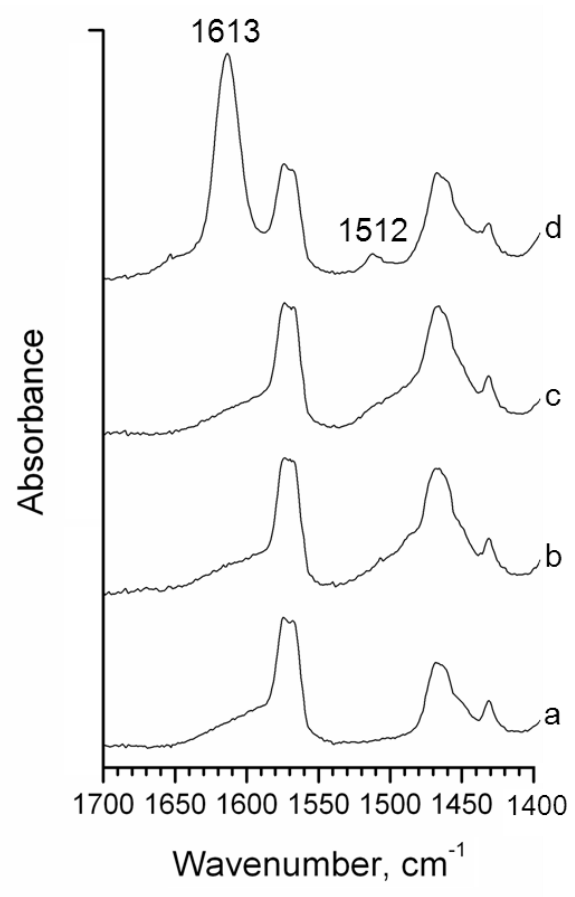

Figure IV-7. ATR-FTIR spectra of (a) $0.1 \mathrm{M} \mathrm{Nd}\left(\mathrm{Tf}_{2} \mathrm{~N}\right)_{3}$ in $[\mathrm{Bmim}]\left[\mathrm{Tf}_{2} \mathrm{~N}\right]$, (b) $0.1 \mathrm{M} \mathrm{Nd}\left(\mathrm{Tf}_{2} \mathrm{~N}\right)_{3}$ $+0.3 \mathrm{M}$ TBAN in $[\mathrm{Bmim}]\left[\mathrm{Tf}_{2} \mathrm{~N}\right]$, (c) $0.1 \mathrm{M} \mathrm{Nd}\left(\mathrm{Tf}_{2} \mathrm{~N}\right)_{3}+0.3 \mathrm{M} \mathrm{TBAN}+0.3 \mathrm{M} \mathrm{TBP}$ in $[\mathrm{Bmim}]\left[\mathrm{Tf}_{2} \mathrm{~N}\right]$, and (c) $0.1 \mathrm{M} \mathrm{Nd}\left(\mathrm{Tf}_{2} \mathrm{~N}\right)_{3}+0.3 \mathrm{M}$ TBAN + 0.3 M TBP + 0.3 M TBDGA in $[\mathrm{Bmim}]\left[\mathrm{Tf}_{2} \mathrm{~N}\right]$. 


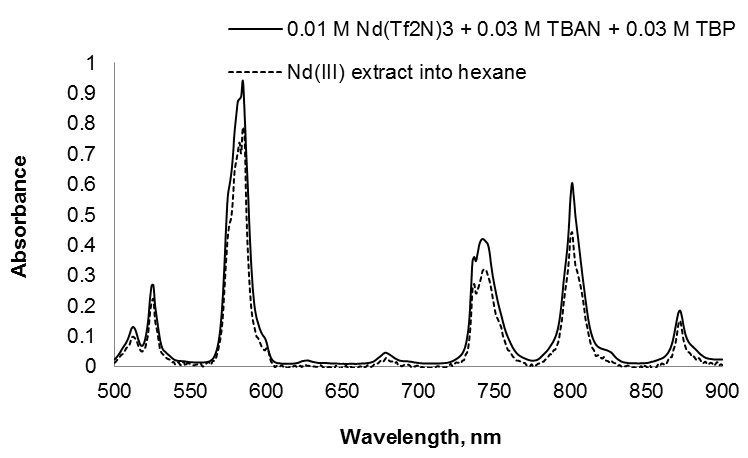

Figure IV-8. UV/Vis spectrum of $\mathrm{Nd}\left(\mathrm{NO}_{3}\right)_{3}(\mathrm{TBP})_{3}$ in hexane (solid line) and the spectrum of the $[\mathrm{Bmim}]\left[\mathrm{Tf}_{2} \mathrm{~N}\right]$ solution containing molar ratio of $\mathrm{Nd}\left(\mathrm{Tf}_{2} \mathrm{~N}\right)_{3} \cdot 2 \mathrm{H}_{2} \mathrm{O}: \mathrm{TBAN}: \mathrm{TBP}=1: 3: 3$ (dotted line).

\section{IV-3. Solubility and Distribution Ratio of $\mathrm{UO}_{2}\left(\mathrm{NO}_{3}\right)_{2}(\mathrm{TBP})_{2}$ and $\mathrm{Nd}\left(\mathrm{NO}_{3}\right)_{3}(\mathrm{TBP})_{3}$ in}

\section{Supercritical $\mathrm{CO}_{2}$ Phase}

The solubility of $\mathrm{UO}_{2}\left(\mathrm{NO}_{3}\right)_{2}(\mathrm{TBP})_{2}$ in $\mathrm{sc}-\mathrm{CO}_{2}$ is known, but that of $\mathrm{Nd}\left(\mathrm{NO}_{3}\right)_{3}(\mathrm{TBP})_{3}$ is unknown. Hence, the complex $\mathrm{Nd}\left(\mathrm{NO}_{3}\right)_{3}(\mathrm{TBP})_{3}$ was prepared by following a similar method reported in the literature for synthesizing $\mathrm{UO}_{2}\left(\mathrm{NO}_{3}\right)_{2}(\mathrm{TBP})_{2}{ }^{3}$ About $4 \mathrm{~mL}$ of the synthesized $\mathrm{Nd}\left(\mathrm{NO}_{3}\right)_{3}(\mathrm{TBP})_{3}$ complex were placed in a $24 \mathrm{~mL}$ high pressure fiber-optic cell connected to a CCD array UV-Vis spectrometer for static supercritical fluid extraction (SFE). The UV-Vis spectra of the extraction system were taken at $40{ }^{\circ} \mathrm{C}$ and a pressure of $150 \mathrm{~atm}$ or $200 \mathrm{~atm}$ of $\mathrm{CO}_{2}$. The pathlength of the optical fiber was about $0.35 \mathrm{~cm}$. The molar absorptivity of $\mathrm{Nd}\left(\mathrm{NO}_{3}\right)_{3}(\mathrm{TBP})_{3}$ at $801 \mathrm{~nm}$ was determined to be $7.84 \mathrm{~mol}^{-1} \mathrm{~cm}^{-1}$ in the hexane phase. Hexane has a similar polarity to $\mathrm{CO}_{2}$ and $\mathrm{UV} / \mathrm{V}$ is spectra have been shown to exhibit similar absorption coefficients for metal chelates in both solvents. ${ }^{30}$ Thus, the molar absorptivity of a compound measured in hexane can be used to evaluate its absorption in $\mathrm{sc}-\mathrm{CO}_{2}$. The concentration of $\mathrm{Nd}\left(\mathrm{NO}_{3}\right)_{3}(\mathrm{TBP})_{3}$ complex in sc- $\mathrm{CO}_{2}$ was measured using this molar absorptivity and Beer's law. The solubility of $\mathrm{Nd}\left(\mathrm{NO}_{3}\right)_{3}(\mathrm{TBP})_{3}$ in sc- $\mathrm{CO}_{2}$ is compared to that of $\mathrm{UO}_{2}\left(\mathrm{NO}_{3}\right)_{2}(\mathrm{TBP})_{2}$ as shown in Table 1.

Table 1. Solubility $(\mathrm{mol} / \mathrm{L})$ of $\mathrm{Nd}\left(\mathrm{NO}_{3}\right)_{3}(\mathrm{TBP})_{3}$ in supercritical $\mathrm{CO}_{2}$ (at $40^{\circ} \mathrm{C}$ )

\begin{tabular}{cllc} 
Complexes & $150 \mathrm{~atm}$ & $200 \mathrm{~atm}$ & \\
\hline $\mathbf{N d}\left(\mathbf{N O}_{\mathbf{3}}\right)_{\mathbf{3}}(\mathbf{T B P})_{\mathbf{3}}$ & $1.7 \times 10^{-2}$ & $7.8 \times 10^{-2}$ & This work \\
\hline $\mathbf{U O}_{\mathbf{2}}\left(\mathbf{N O}_{\mathbf{3}} \mathbf{2}_{\mathbf{2}} \mathbf{( T B P}\right)_{\mathbf{2}}$ & $7.0 \times 10^{-2}$ & $4.2 \times 10^{-1}$ & Ref. $^{3}$ \\
\hline
\end{tabular}


The $\mathrm{UO}_{2}\left(\mathrm{NO}_{3}\right)_{2}(\mathrm{TBP})_{2}$ and $\mathrm{Nd}\left(\mathrm{NO}_{3}\right)_{3}(\mathrm{TBP})_{3}$ complexes were dissolved in [Bmim] $\mathrm{Tf}_{2} \mathrm{~N}$ ] for sc- $\mathrm{CO}_{2}$ extraction at $40{ }^{\circ} \mathrm{C}$ and 200 atm. The distribution coefficient is defined as the molar ratio of the metal complex in sc- $\mathrm{CO}_{2}$ over that in the IL. We placed $1 \mathrm{~mL}$ of the IL containing $1.5 \times 10^{-4}$ mole of $\mathrm{UO}_{2}\left(\mathrm{NO}_{3}\right)_{2}(\mathrm{TBP})_{2}$ or $\mathrm{Nd}\left(\mathrm{NO}_{3}\right)_{3}(\mathrm{TBP})_{3}$ in the extraction cell for static supercritical fluid extraction. The cell was preheated to $40{ }^{\circ} \mathrm{C}$ and $\mathrm{CO}_{2}$ gas was pressurized to $200 \mathrm{~atm}$. The static SFE processes were monitored at $414 \mathrm{~nm}$ for uranyl experiments and at 801 $\mathrm{nm}$ for neodymium experiments using the fiber-optic UV/Vis spectrometer (Figure IV-1). The results are given in Figure IV-9. Extraction of uranyl and neodymium species from the IL phase to the sc- $\mathrm{CO}_{2}$ was virtually complete in 10 minutes indicating the mass transfer of these complexes from the IL to sc- $\mathrm{CO}_{2}$ phase was very rapid. The UV/Vis spectrum of the extracted $\mathrm{UO}_{2}\left(\mathrm{NO}_{3}\right)_{2}(\mathrm{TBP})_{2}$ in sc- $\mathrm{CO}_{2}$ was described in the literature. ${ }^{3}$ A typical UV/Vis spectrum of $\mathrm{Nd}\left(\mathrm{NO}_{3}\right)_{3}(\mathrm{TBP})_{3}$ in sc- $\mathrm{CO}_{2}$ phase is shown in Figure 10. The neodymium complex dissolved in sc- $\mathrm{CO}_{2}$ was recovered by releasing pressure and the exiting fluid was collected in a hexane trap solution. The UV/Vis spectrum of neodymium species in sc- $\mathrm{CO}_{2}$ phase is the same as that found in the hexane phase, indicating the formation of $\mathrm{Nd}\left(\mathrm{NO}_{3}\right)_{3}(\mathrm{TBP})_{3}$ complex in both solvents. The distribution ratios of $\mathrm{UO}_{2}\left(\mathrm{NO}_{3}\right)_{2}(\mathrm{TBP})_{2}$ and $\mathrm{Nd}\left(\mathrm{NO}_{3}\right)_{3}(\mathrm{TBP})_{3}$ calculated using Beer's law were found to be 1.42 and 0.22 , respectively.

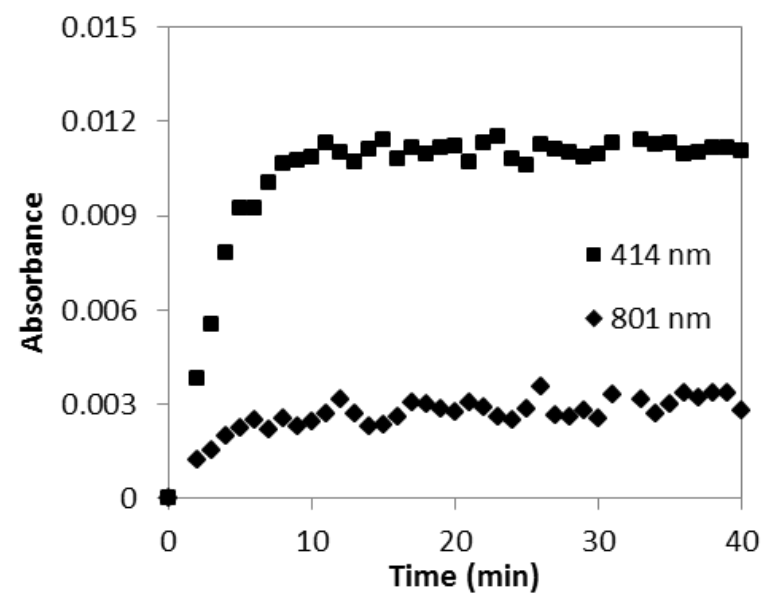

Figure IV-9. Static extraction of $\mathrm{UO}_{2}\left(\mathrm{NO}_{3}\right)_{2}(\mathrm{TBP})_{2}$ (at $\left.414 \mathrm{~nm}\right)$ and $\mathrm{Nd}\left(\mathrm{NO}_{3}\right)_{3}(\mathrm{TBP})_{3}$ (at 801 $\mathrm{nm})$ from $[\mathrm{Bmim}]\left[\mathrm{Tf}_{2} \mathrm{~N}\right]$ into $\mathrm{sc}-\mathrm{CO}_{2}$ phase. 


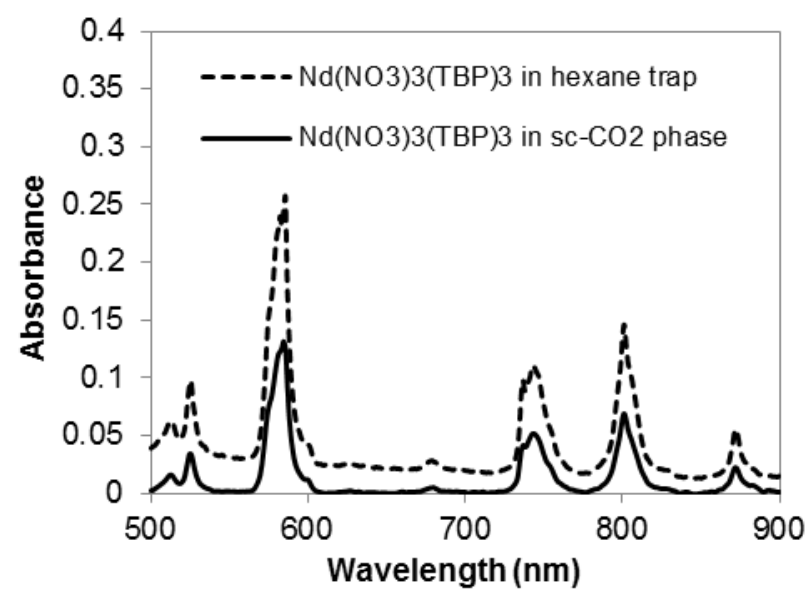

Figure IV-10. UV/Vis spectrum of $\mathrm{Nd}\left(\mathrm{NO}_{3}\right)_{3}(\mathrm{TBP})_{3}$ in the sc- $\mathrm{CO}_{2}$ phase (solid line) and in a hexane trap solution (dash line).

\section{IV-4. Supercritical Fluid Extraction for Separation of Uranium and Neodymium}

According to the literature, ${ }^{31}$ diglycolamide TBDGA ligand is more favorable to coordinate with trivalent lanthanide ion than with uranyl ion. Our study shows that TBDGA can replace both TBP and nitrate in $\mathrm{UO}_{2}\left(\mathrm{NO}_{3}\right)_{2}(\mathrm{TBP})_{2}$ and $\mathrm{Nd}\left(\mathrm{NO}_{3}\right)_{3}(\mathrm{TBP})_{3}$, forming $\mathrm{CO}_{2}$ insoluble complexes in $[\mathrm{Bmim}]\left[\mathrm{Tf}_{2} \mathrm{~N}\right]$. Thus, sc- $\mathrm{CO}_{2}$ extraction of $\mathrm{UO}_{2}\left(\mathrm{NO}_{3}\right)_{2}(\mathrm{TBP})_{2}$ and $\mathrm{Nd}\left(\mathrm{NO}_{3}\right)_{3}(\mathrm{TBP})_{3}$ from the IL in the presence of TBDGA may provide a method of separating uranium and neodymium. To test this idea, $\mathrm{sc}-\mathrm{CO}_{2}$ extraction experiments were carried out with different amounts of TBDGA in $1 \mathrm{~mL}[\mathrm{Bmim}]\left[\mathrm{Tf}_{2} \mathrm{~N}\right]$ containing $1.5 \times 10^{-4}$ mole of each of $\mathrm{UO}_{2}\left(\mathrm{NO}_{3}\right)_{2}(\mathrm{TBP})_{2}$ and $\mathrm{Nd}\left(\mathrm{NO}_{3}\right)_{3}(\mathrm{TBP})_{3}$ species. The results of static sc- $\mathrm{CO}_{2}$ extraction conducted at $40^{\circ} \mathrm{C}$ and $200 \mathrm{~atm}$ are summarized in Table 2. When the extraction was carried out without an excess of TBP in the IL, the extraction efficiencies of $\mathrm{UO}_{2}\left(\mathrm{NO}_{3}\right)_{2}(\mathrm{TBP})_{2}$ and $\mathrm{Nd}\left(\mathrm{NO}_{3}\right)_{3}(\mathrm{TBP})_{3}$ into the sc- $\mathrm{CO}_{2}$ phase were estimated to be $58.7 \%$ and $17.9 \%$, respectively. When an excess amount of TBP $(30 \% \mathrm{v} / \mathrm{v})$ was used in the IL solution for the static sc- $\mathrm{CO}_{2}$ extraction, the result showed an increase in the extraction efficiency to about $81 \%$ for $\mathrm{UO}_{2}\left(\mathrm{NO}_{3}\right)_{2}(\mathrm{TBP})_{2}$ and $29.3 \%$ for $\mathrm{Nd}\left(\mathrm{NO}_{3}\right)_{3}(\mathrm{TBP})_{3}$. The distribution ratios of uranyl and neodymium were also found to increase with increasing TBP (Table 2). When the extraction was conducted with $7.5 \times 10^{-5}$ mole TBDGA (molar ratio of $\mathrm{UO}^{2+}: \mathrm{Nd}^{3+}:$ TBDGA=1:1:0.5) in $1 \mathrm{~mL}$ $[\mathrm{Bmim}]\left[\mathrm{Tf}_{2} \mathrm{~N}\right]$ with $30 \%(\mathrm{v} / \mathrm{v}) \mathrm{TBP}$, the extraction efficiency of $\mathrm{Nd}\left(\mathrm{NO}_{3}\right)_{3}(\mathrm{TBP})_{3}$ in the sc- $\mathrm{CO}_{2}$ phase decreased from 29.3 to $21.2 \%$. At the same time, the extraction efficiency of $\mathrm{UO}_{2}\left(\mathrm{NO}_{3}\right)_{2}(\mathrm{TBP})_{2}$ into sc- $\mathrm{CO}_{2}$ was only reduced slightly (Table 2). This result agrees with the 
fact that TBDGA is favored to coordinate with $\mathrm{Nd}^{3+}$ than with $\left(\mathrm{UO}_{2}\right)^{2+}$. When the extraction was carried out with $1.5 \times 10^{-4}$ mole TBDGA (molar ratio of $\mathrm{UO}^{2+}: \mathrm{Nd}^{3+}:$ TBDGA $=1: 1: 1$ ) in $1 \mathrm{~mL}$ $[\mathrm{Bmim}]\left[\mathrm{Tf}_{2} \mathrm{~N}\right]$ with $30 \%(\mathrm{v} / \mathrm{v}) \mathrm{TBP}$, the extraction efficiency of $\mathrm{Nd}\left(\mathrm{NO}_{3}\right)_{3}(\mathrm{TBP})_{3}$ into sc- $\mathrm{CO}_{2}$ phase was not detectable in the sc- $\mathrm{CO}_{2}$ phase. However, the extraction efficiency of $\mathrm{UO}_{2}\left(\mathrm{NO}_{3}\right)_{2}(\mathrm{TBP})_{2}$ in the $\mathrm{CO}_{2}$ phase remained at a relative high value (Table 2). Under these conditions, separation of uranium from neodymium can be achieved in this IL-sc-CO $\mathrm{CO}_{2}$ system.

Table 2. Static extraction of uranyl and neodymium species from ionic liquid phase to supercritical $\mathrm{CO}_{2}$ phase at $40{ }^{\circ} \mathrm{C}$ and 200 atm. The errors of static sc- $\mathrm{CO}_{2}$ extractions are less than $5 \%$ based on repeat experiments.

\begin{tabular}{|c|c|c|c|c|c|}
\hline \multirow[b]{2}{*}{$\mathrm{Sc}-\mathrm{CO}_{2}$ Composition } & \multicolumn{2}{|c|}{ Extraction $(\%)$} & \multicolumn{2}{|c|}{ Distribution ratio } & \multirow{2}{*}{$\begin{array}{l}\text { Separation factor } \\
\qquad\left[\mathrm{UO}_{2}{ }^{2+} / \mathrm{Nd}^{3+}\right]\end{array}$} \\
\hline & $\mathrm{U}(\mathrm{VI})$ & $\mathrm{Nd}(\mathrm{III})$ & $\mathrm{D}_{\mathrm{U}}$ & $\mathrm{D}_{\mathrm{Nd}}$ & \\
\hline Neat $\mathrm{CO}_{2}$ & 58.7 & 17.9 & 1.4 & 0.22 & 3.3 \\
\hline $30 \%$ TBP & 81.0 & 29.3 & 4.3 & 0.41 & 2.8 \\
\hline $\begin{array}{l}30 \% \text { TBP }+7.5 \times 10^{-5} \text { mol TBDGA } \\
\left(\mathrm{UO}_{2}{ }^{2+}: \mathrm{Nd}^{3+}: \text { TBDGA }=1: 1: 0.5\right)\end{array}$ & 80.4 & 21.2 & 4.1 & 0.26 & 3.8 \\
\hline $\begin{array}{l}30 \% \mathrm{TBP}+1.5 \times 10^{-4} \mathrm{~mol} \text { TBDGA } \\
\left(\mathrm{UO}_{2}^{2+}: \mathrm{Nd}^{3+}: \text { TBDGA }=1: 1: 1\right)\end{array}$ & 76.5 & ND & 3.3 & - & \\
\hline $\begin{array}{l}30 \% \mathrm{TBP}+1.9 \times 10^{-4} \mathrm{~mol} \text { TBDGA } \\
\left(\mathrm{UO}_{2}^{2+}: \mathrm{Nd}^{3+}: \text { TBDGA }=1: 1: 1.25\right)\end{array}$ & 71.8 & ND & 2.6 & - & \\
\hline $\begin{array}{l}30 \% \mathrm{TBP}+2.3 \times 10^{-4} \mathrm{~mol} \text { TBDGA } \\
\left(\mathrm{UO}_{2}^{2+}: \mathrm{Nd}^{3+}: \text { TBDGA }=1: 1: 1.5\right)\end{array}$ & 65.9 & ND & 1.9 & - & \\
\hline
\end{tabular}

Note: Monitored at $414 \mathrm{~nm}$ for $\mathrm{UO}_{2}\left(\mathrm{NO}_{3}\right)_{2}(\mathrm{TBP})_{2}$ and at $801 \mathrm{~nm}$ for $\mathrm{Nd}\left(\mathrm{NO}_{3}\right)_{3}(\mathrm{TBP})_{3}$ in sc- $\mathrm{CO}_{2}$ phase; $\mathrm{ND}=$ not detectable.

\section{IV-5. Dynamic Supercritical Fluid Extraction for Separation of Uranium and Neodymium}

Dynamic sc- $\mathrm{CO}_{2}$ extraction experiments were carried out with $40 \mathrm{~min}$ of static extraction at $40{ }^{\circ} \mathrm{C}$ and $200 \mathrm{~atm}$ followed by $2.5 \mathrm{~h}$ of dynamic extraction at a flow rate of $0.3-0.4 \mathrm{~mL} / \mathrm{min}$. After that, the system was depressurized to atmospheric pressure in about $1 \mathrm{~h}$. The $\mathrm{UO}_{2}\left(\mathrm{NO}_{3}\right)_{2}(\mathrm{TBP})_{2}$ and $\mathrm{Nd}\left(\mathrm{NO}_{3}\right)_{3}(\mathrm{TBP})_{3}$ carried out by sc- $\mathrm{CO}_{2}$ during dynamic extraction and were collected by a hexane trap solution. The results of the dynamic sc- $\mathrm{CO}_{2}$ extraction of 
$\mathrm{UO}_{2}\left(\mathrm{NO}_{3}\right)_{2}(\mathrm{TBP})_{2}$ and $\mathrm{Nd}\left(\mathrm{NO}_{3}\right)_{3}(\mathrm{TBP})_{3}$ from $[\mathrm{Bmim}]\left[\mathrm{Tf}_{2} \mathrm{~N}\right]$ to hexane trap solution are given in Table 3. When the molar ratio of $\mathrm{Nd}^{3+}$ to TBDGA was increased from 1:0.5 to $1: 1.5$ in the IL solution, the extraction of neodymium was dramatically reduced from $20.9 \%$ to $<1 \%$ in the hexane trap solution. The amount of $\mathrm{UO}_{2}\left(\mathrm{NO}_{3}\right)_{2}(\mathrm{TBP})_{2}$ collected in the hexane trap solution was about half of the original amount in the IL phase. The separation factor of $\left[\mathrm{UO}_{2}{ }^{2+}\right] /\left[\mathrm{Nd}^{3+}\right]$ is increased from 2.8 in the absence of TBDGA to about 50 with the addition of TBDGA at ratios of $\mathrm{UO}_{2}{ }^{2+}: \mathrm{Nd}^{3+}:$ TBDGA $=1: 1: 1.5$.

The extraction efficiency $(E)$ in the hexane trap is defined as:

$$
E \%=\frac{\mathrm{UO}_{2}\left(\mathrm{NO}_{3}\right)_{2}(\mathrm{TBP}) \text { and } \mathrm{Nd}\left(\mathrm{NO}_{3}\right)_{3}(\mathrm{TBP})_{3} \text { in } 5 \mathrm{~mL} \text { hexane trap solution }(\mathrm{mol})}{\mathrm{UO}_{2} \text { and } \mathrm{Nd}_{2} \mathrm{O}_{3} \text { dissolved in the IL (mol) }}
$$

The overall results demonstrate the principle that separation of uranium from lanthanides can be achieved using static/dynamic sc- $\mathrm{CO}_{2}$ extraction utilizing diglycolamide as a competing ligand for their nitrate-TBP complexes dissolved in the IL phase.

Table 3. Dynamic extraction of uranyl and neodymium complex from ionic liquid phase into the hexane trap solution using sc- $\mathrm{CO}_{2}$ at $200 \mathrm{~atm}$ and $40{ }^{\circ} \mathrm{C}$.

\begin{tabular}{|c|c|c|c|}
\hline \multirow[b]{2}{*}{$\mathrm{Sc}-\mathrm{CO}_{2}$ Composition } & \multicolumn{2}{|c|}{$\%$ Extraction } & \multirow{2}{*}{$\begin{array}{l}\text { Separation factor } \\
\qquad\left[\mathrm{UO}_{2}{ }^{2+} / \mathrm{Nd}^{3+}\right]\end{array}$} \\
\hline & $\mathrm{U}(\mathrm{VI})$ & $\mathrm{Nd}(\mathrm{III})$ & \\
\hline $\begin{array}{l}\text { a } 30 \% \mathrm{TBP}+7.5 \times 10^{-5} \mathrm{~mol} \text { TBDGA } \\
\left(\mathrm{UO}_{2}{ }^{2+}: \mathrm{Nd}^{3+}: \text { TBDGA }=1: 1: 0.5\right)\end{array}$ & $76.3 \pm 3.4$ & $20.9 \pm 2.0$ & $3.7 \pm 0.4$ \\
\hline $\begin{array}{l}\text { a } 30 \% \mathrm{TBP}+1.5 \times 10^{-4} \mathrm{~mol} \text { TBDGA } \\
\left(\mathrm{UO}_{2}{ }^{2+}: \mathrm{Nd}^{3+}: \text { TBDGA }=1: 1: 1\right)\end{array}$ & $69.2 \pm 3.1$ & $7.7 \pm 0.4$ & $9.0 \pm 0.6$ \\
\hline $\begin{array}{l}\text { a } 30 \% \mathrm{TBP}+1.9 \times 10^{-4} \mathrm{~mol} \text { TBDGA } \\
\left(\mathrm{UO}_{2}{ }^{2+}: \mathrm{Nd}^{3+}: \text { TBDGA }=1: 1: 1.25\right)\end{array}$ & $65.3 \pm 1.9$ & $4.6 \pm 0.2$ & $14.5 \pm 0.8$ \\
\hline $\begin{array}{l}\text { b } 30 \% \text { TBP }+2.3 \times 10^{-4} \text { mol TBDGA } \\
\left(\mathrm{UO}_{2}{ }^{2+}: \mathrm{Nd}^{3+}: \text { TBDGA }=1: 1: 1.5\right)\end{array}$ & $49.2 \pm 2.5$ & $<1$ & $>49.2 \pm 2.5$ \\
\hline
\end{tabular}

${ }^{a}$ Experimental condition: $40 \mathrm{~min}$ static extraction and $3.5 \mathrm{~h}$ dynamic extraction (flow rate $0.3-0.4 \mathrm{~mL} / \mathrm{min}$ ) including depressurization $(\sim 1 \mathrm{~h})$. ${ }^{\mathrm{b}}$ Experimental condition: $40 \mathrm{~min}$ static extraction and $4 \mathrm{~h}$ dynamic extraction (flow rate $0.3-0.4 \mathrm{~mL} / \mathrm{min}$ ) including depressurization $(\sim 1 \mathrm{~h})$. 
After each sc- $\mathrm{CO}_{2}$ extraction experiment, an infrared spectrum was taken from the IL solution left in the extraction cell. When the concentration of uranyl-TBDGA species in the IL is low, the vibrational stretching mode $v_{\text {as }}$ of $\mathrm{UO}_{2}{ }^{2+}$ overlaps with the vibrational mode of $[\mathrm{Bmim}]\left[\mathrm{Tf}_{2} \mathrm{~N}\right]$ around $950 \mathrm{~cm}^{-1}$ (Figure IV-11A-c to -e). When the concentration of uranylTBDGA species was about $50 \%$ in the IL solution, the $v_{\text {as }}\left(\mathrm{UO}_{2}\right)$ was observed at $942 \mathrm{~cm}^{-1}$ in the IR spectrum (Figure IV-11A-f). This $v_{\text {as }}\left(\mathrm{UO}_{2}\right)$ mode may correspond to that of $\mathrm{UO}_{2}\left(\mathrm{NO}_{3}\right)_{2}$ (TBDGA) species shown in Figure IV-4-a. The small peak at about $913 \mathrm{~cm}^{-1}$ may be related to the vibrational mode of $-\mathrm{C}-\mathrm{C}$ - of TBP. The bonded $\mathrm{C}=\mathrm{O}$ group $\left(1613 \mathrm{~cm}^{-1}\right)$ can also be detected as shown in Figure IV-11B and the intensity of $\mathrm{C}=\mathrm{O}$ absorbance peaks are increased with increasing the concentration of uranyl-TBDGA and neodymium-TBDGA complexes in the IL (Figure IV-11B-c to -e). From the combined results of sc- $\mathrm{CO}_{2}$ dynamic extraction (Table 3) and IR spectra (Figure IV-11), we may conclude that the uranyl-TBDGA complex left in IL has a molar ratio of $\mathrm{UO}_{2}^{2+}:$ TBDGA $=1: 1$ and the neodymium-TBDGA complex also has a $\mathrm{Nd}^{3+}$ : TBDGA ratio $=1: 1$ based on a mass balance consideration.
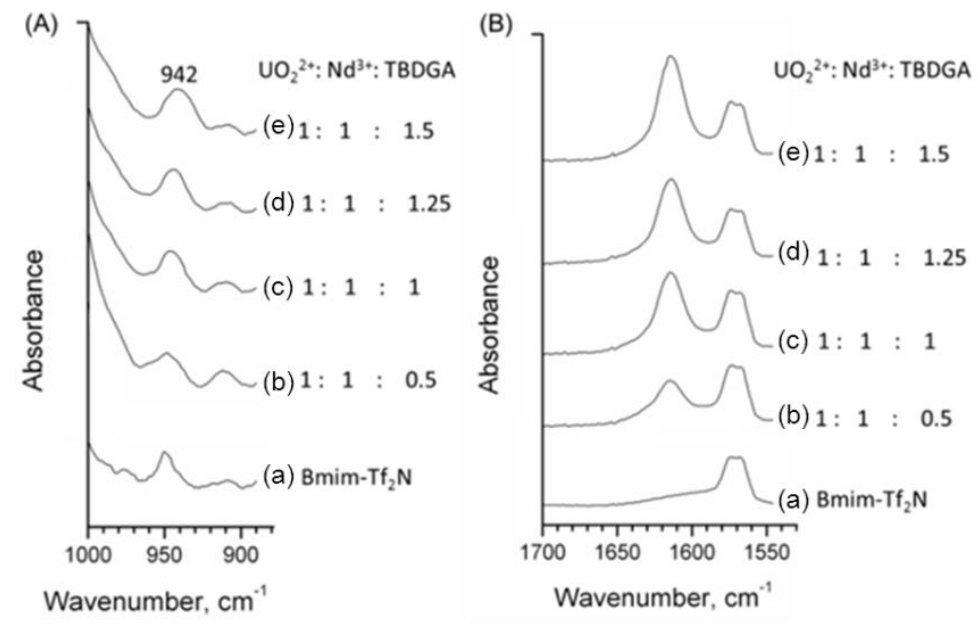

Figure IV-11. ATR-FTIR spectra of $[\mathrm{Bmim}]\left[\mathrm{Tf}_{2} \mathrm{~N}\right]$ solutions left in the $\mathrm{CO}_{2}$ extraction cell, (A) in the $v_{\mathrm{as}}\left(\mathrm{UO}_{2}\right)$ region and $(\mathrm{B})$ in the $\mathrm{v}(\mathrm{C}=\mathrm{O})$ region.

\section{IV-5. Summary}

The coordination of $\mathrm{UO}_{2}{ }^{2+}$ and $\mathrm{Nd}^{3+}$ with diglycolamide in the ionic liquid [Bmim] $\left[\mathrm{Tf}_{2} \mathrm{~N}\right]$ is investigated using Raman and IR spectroscopy. The results of IR and Raman spectra indicate that TBDGA is a stronger ligand than both TBP and nitrate for complexation with $\mathrm{UO}_{2}{ }^{2+}$ and 
$\mathrm{Nd}^{3+}$ and the resulting TBDGA complexes are not soluble in $\mathrm{sc}-\mathrm{CO}_{2}$. The solubility of $\mathrm{Nd}\left(\mathrm{NO}_{3}\right)_{3}(\mathrm{TBP})_{3}$ in sc- $\mathrm{CO}_{2}$ has been measured at $40{ }^{\circ} \mathrm{C}$ from $150 \mathrm{~atm}$ to $200 \mathrm{~atm}$. The distribution ratios of $\mathrm{UO}_{2}\left(\mathrm{NO}_{3}\right)_{2}(\mathrm{TBP})_{2}$ and $\mathrm{Nd}\left(\mathrm{NO}_{3}\right)_{3}(\mathrm{TBP})_{3}$ between $[\mathrm{Bmim}]\left[\mathrm{Tf}_{2} \mathrm{~N}\right]$ and sc- $\mathrm{CO}_{2}$ phase have also been evaluated to be 1.42 and 0.22 , respectively, at $40{ }^{\circ} \mathrm{C}$ and $200 \mathrm{~atm}$. Static and dynamic sc- $\mathrm{CO}_{2}$ extractions show that a large separation factor of $\left[\mathrm{UO}_{2}{ }^{2+}\right] /\left[\mathrm{Nd}^{3+}\right]$ can be achieved by controlling the amount of TBDGA ligand added to the IL phase. The $\mathrm{CO}_{2}$-insoluble uranyl-TBDGA species left in the IL phase is identified to be $\mathrm{UO}_{2}\left(\mathrm{NO}_{3}\right)_{2}$ (TBDGA). The overall results of this study suggest that separation of uranium from lanthanides can be achieved using an $\mathrm{IL}$ and sc- $\mathrm{CO}_{2}$ coupled dissolution/extraction process utilizing TBDGA as a competing ligand for the uanyl and lanthanide-nitrate-TBP complexes dissolved in the IL phase. The fraction of uranium extracted by sc- $\mathrm{CO}_{2}$ depends on the relative amount of the two metals in the IL phase and the amount of TBDGA added to the IL system. 


\section{Chapter V. Other Related Studies}

\section{V-1. Total Reflection-Fourier Transform Study of Uranyl Nitrate Species in Ionic Liquid}

Room temperature ionic liquids are potentially important solvents for developing novel nuclear waste treatment methods. The solvation, speciation, and complexation behaviors of actinides and lanthanides in room temperature ionic liquids are of current interest. We have studied the coordination environment of uranyl $(\mathrm{O}=\mathrm{U}=\mathrm{O})^{2+}$ in solutions of the room temperature ionic liquid 1-butyl-3-methylimidazolium bis(trifluoromethylsulfonyl)imide ([Bmim][Tf $\left.\left.{ }_{2} \mathrm{~N}\right]\right)$, containing either tetrabutylammonium nitrate (TBAN) or nitric acid using attenuated total reflection-Fourier transform infrared spectrometry. Both $\mathrm{UO}_{2}\left(\mathrm{NO}_{3}\right)_{2}$ and $\mathrm{UO}_{2}\left(\mathrm{NO}_{3}\right)_{3}{ }^{-}$species were detected in solutions containing tetrabutylammonium nitrate. The asymmetric vibrational mode $v_{\text {as }}\left(\mathrm{UO}_{2}\right)$ for these two species were found to lie at 951 and $944 \mathrm{~cm}^{-1}$, respectively, while $v_{\text {as }}\left(\mathrm{UO}_{2}\right)$ arising from uranyl coordinated by $\mathrm{Tf}_{2} \mathrm{~N}$ anions in $[\mathrm{Bmim}]\left[\mathrm{Tf}_{2} \mathrm{~N}\right]$ was found to lie at $968 \mathrm{~cm}^{-1}$. In solutions containing nitric acid, only $\mathrm{UO}_{2}\left(\mathrm{NO}_{3}\right)_{2}$ was detected, due to the high water content. The $\mathrm{UO}_{2}\left(\mathrm{NO}_{3}\right)^{+}$species was not detected in $[\mathrm{Bmim}]\left[\mathrm{Tf}_{2} \mathrm{~N}\right]$ under the conditions used in the study. This part of the spectroscopic study was published in a paper entitled "Characterization of Uranyl(VI) Nitrate Complexes in a Room Temperature Ionic Liquid Using Attenuated Total Reflection-Fourier Transform Infrared Spectrometry" (Inorganic Chemistry, 2010, 49, 8568-8572). The paper is attached in the Appendix of this report.

Later, we found that the $v_{\text {as }}\left(\mathrm{UO}_{2}\right)$ of $\mathrm{UO}_{2}\left(\mathrm{NO}_{3}\right)^{+}$species can be identified in a different ionic liquid 1-methyl-3-octylimidazolium bis(trifluoromethylsulfonyl)imide ([Omim][Tf $\left.\mathrm{T}_{2} \mathrm{~N}\right]$ ) when $\mathrm{UO}_{2}\left(\mathrm{Tf}_{2} \mathrm{~N}\right)_{2}$ (uranyl bis(trifluoromethylsulfonyl)imide) is mixed with nitric acid. In the $[\mathrm{Bmim}]\left[\mathrm{Tf}_{2} \mathrm{~N}\right]$ system, the $v_{\text {as }}\left(\mathrm{UO}_{2}\right)$ of $\mathrm{UO}_{2}\left(\mathrm{NO}_{3}\right)^{+}$species is buried under the background of the ionic liquid and is not detectable. Figure V-1 shows that the $v_{\mathrm{as}}\left(\mathrm{UO}_{2}\right)$ of $\mathrm{UO}_{2}\left(\mathrm{Tf}_{2} \mathrm{~N}\right)_{2}$ alone in [Omim] $\left[\mathrm{Tf}_{2} \mathrm{~N}\right]$ occurs at $968 \mathrm{~cm}^{-1}$. When different amounts of nitric acid is added to the system, the $v_{\text {as }}\left(\mathrm{UO}_{2}\right)$ shifts to lower wave numbers. When the molar ratio of uranyl : nitrate $=1: 1$, the $v_{\text {as }}\left(\mathrm{UO}_{2}\right)$ occurs at $956 \mathrm{~cm}^{-1}$ which is assigned to the $\mathrm{UO}_{2}\left(\mathrm{NO}_{3}\right)^{+}$species. At molar ratios of uranyl : nitrate $=1: 2$ and 1:3, the $v_{\mathrm{as}}\left(\mathrm{UO}_{2}\right)$ shifts to $951 \mathrm{~cm}^{-1}$. This $v_{\mathrm{as}}\left(\mathrm{UO}_{2}\right)$ is previously assigned to the $\mathrm{UO}_{2}\left(\mathrm{NO}_{3}\right)_{2}$ species. The $\mathrm{UO}_{2}\left(\mathrm{NO}_{3}\right)_{3}{ }^{-}$species does not form when nitric acid is present in the ionic liquid due to the water carried by the acid into the system. 


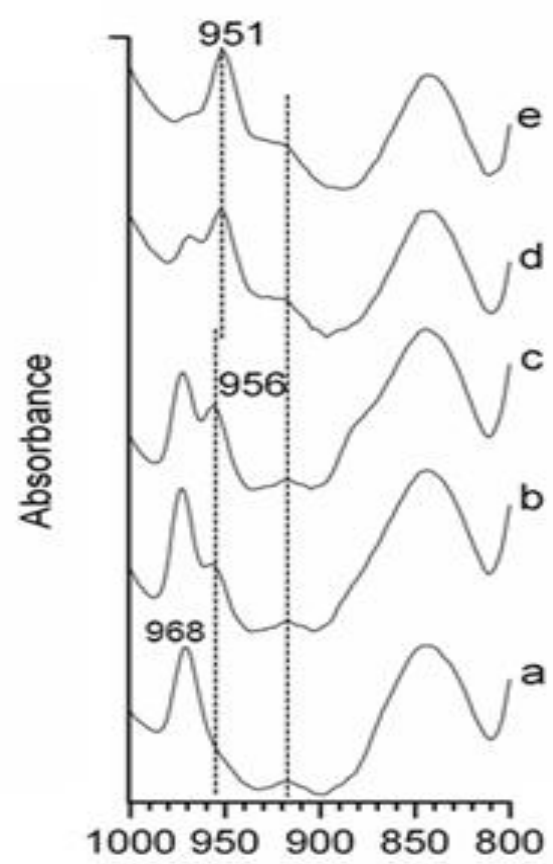

Wavenumber, $\mathrm{cm}^{-1}$

Figure V-1. ATR-FTIR spectra of the $v_{\text {as }}\left(\mathrm{UO}_{2}\right)$ region for solutions of [Omim] $\left[\mathrm{Tf}_{2} \mathrm{~N}\right]$ containing different molar ratio of $\mathrm{UO}_{2}\left(\mathrm{Tf}_{2} \mathrm{~N}\right)_{2}$ and nitric acid. $\mathrm{UO}_{2}{ }^{2+}: \mathrm{HNO}_{3}$ (a) $0.1 \mathrm{M}$ of $\mathrm{UO}_{2}\left(\mathrm{Tf}_{2} \mathrm{~N}\right)_{2}$ only, (b) $1: 0.5$, (c) $1: 1$, (d) $1: 2$, and (e) $1: 3$.

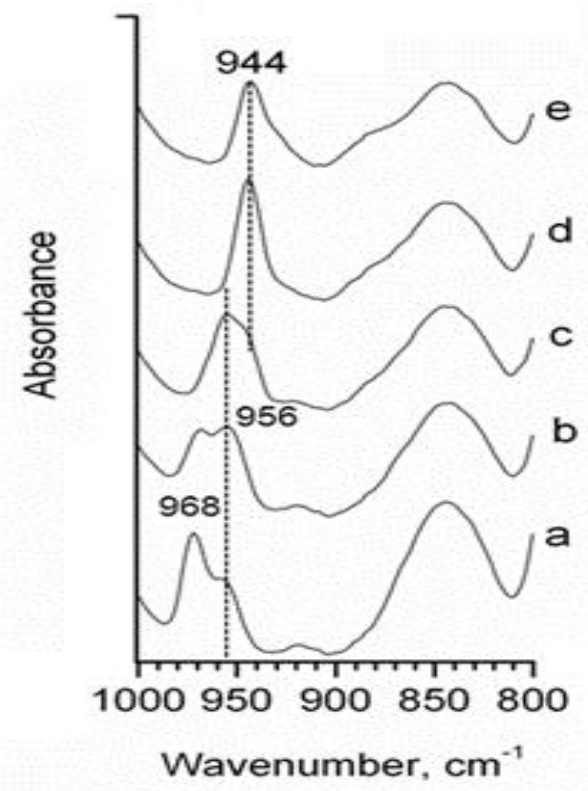

Figure V-2. (A) ATR-FTIR spectra of the $v_{\text {as }}\left(\mathrm{UO}_{2}\right)$ region and (B) Raman spectra of the $v_{\mathrm{s}}\left(\mathrm{UO}_{2}\right)$ region for solutions of [Omim] $\left[\mathrm{Tf}_{2} \mathrm{~N}\right]$ containing with different molar ratio of $\mathrm{UO}_{2}\left(\mathrm{Tf}_{2} \mathrm{~N}\right)_{2}$ and TBAN. $\mathrm{UO}_{2}{ }^{2+}: \operatorname{TBAN}$ (a) $1: 0.5$, (b) $1: 1$, (c) $1: 2$, (d) $1: 3$, and (e) $1: 4$. 
Nitrate ions can also be introduced into the ionic liquid using tetrabutylammonium nitrate (TBAN) which does not carry water into the system. In this case, $v_{\text {as }}\left(\mathrm{UO}_{2}\right)$ occurs at $944 \mathrm{~cm}^{-1}$ when the molar ratio of uranyl : nitrate $=1: 3$ indicating the presence of the $\mathrm{UO}_{2}\left(\mathrm{NO}_{3}\right)_{3}{ }^{-}$species (Figure V-2A-e). At the urayl : nitrate molar ratio of $1: 2$, the $v_{\mathrm{as}}\left(\mathrm{UO}_{2}\right)$ peak is broad (Figure V2A-c) and appears to consist of a mixture of uranyl species probable including $\mathrm{UO}_{2}\left(\mathrm{NO}_{3}\right)^{+}$, $\mathrm{UO}_{2}\left(\mathrm{NO}_{3}\right)_{2}$ and $\mathrm{UO}_{2}\left(\mathrm{NO}_{3}\right)_{3}{ }^{-}$. At the uranyl : nitrate molar ratio of $1: 1$, the $v_{\mathrm{as}}\left(\mathrm{UO}_{2}\right)$ peak occurs at $956 \mathrm{~cm}^{-1}$, which corresponds to the formation of the $\mathrm{UO}_{2}\left(\mathrm{NO}_{3}\right)^{+}$species in the ionic liquid. The significance of this study is that it demonstrates that infrared spectroscopy forms a valuable addition to the suite of tools currently used to study the chemical behavior of uranyl in room temperature ionic liquids.

\section{V-2. The Partitioning of Americium and the Lanthanides Using Tetrabutyldiglycolamide (TBDGA) in Octanol and in Ionic Liquid}

Separations among the lanthanides and the partitioning of Am from the lanthanides are challenging. The Am separation is of interest in nuclear fuel cycle applications, where current proposed reprocessing schemes would separate Am for incorporation into fast-reactor fuels, with disposal of the lanthanides as radioactive fission-product waste. The separation of the adjacent lanthanides is also of current industrial interest. However, the ubiquitous trivalent oxidation state and the narrow range of ionic radii of the lanthanides limit the options available to design such separations. In this study, we characterized the separation of Am and lanthanides using TBDGA $\left(N, N, N^{\prime}, N^{\prime}\right.$-tetrabutyldiglycolamide) as a ligand in the ionic liquid [Bmin] $\left[\mathrm{Tf}_{2} \mathrm{~N}\right]$ and in a molecular solvent octanol. The highest extraction efficiency was found for the extraction of cationic nitrato-species into the ionic liquid; however, higher separation factors for lanthanide and Am/lanthanide separations were achieved in the molecular solvent.

Figure V-3 shows the distribution ratios of the lanthanides between 1-octanol containing $0.007 \mathrm{M}$ of TBDGA and $1 \mathrm{M}$ nitric acid as a function of the ionic radius of the trivalent lanthanide ions. The distribution ratio $\left([\mathrm{Ln}]_{\mathrm{org}} /[\mathrm{Ln}]_{\mathrm{aq}}\right)$ increases with decreasing ionic radius of the lanthanides, i.e. increases from $\mathrm{La}^{3+}$ to $\mathrm{Lu}^{3+}$. The open square in Figure $\mathrm{V}-3$ is $\mathrm{Am}^{3+}$. The distribution ratios of $\mathrm{Eu}^{3+}$ and $\mathrm{Am}^{3+}$ between octanol and nitric acid vary with the acid concentration as shown in Figure V-4. The largest separation factor $\left(\alpha_{\mathrm{Eu} / \mathrm{Am}}\right)$ of 11 was obtained from 6-8 M nitric acid solution. 


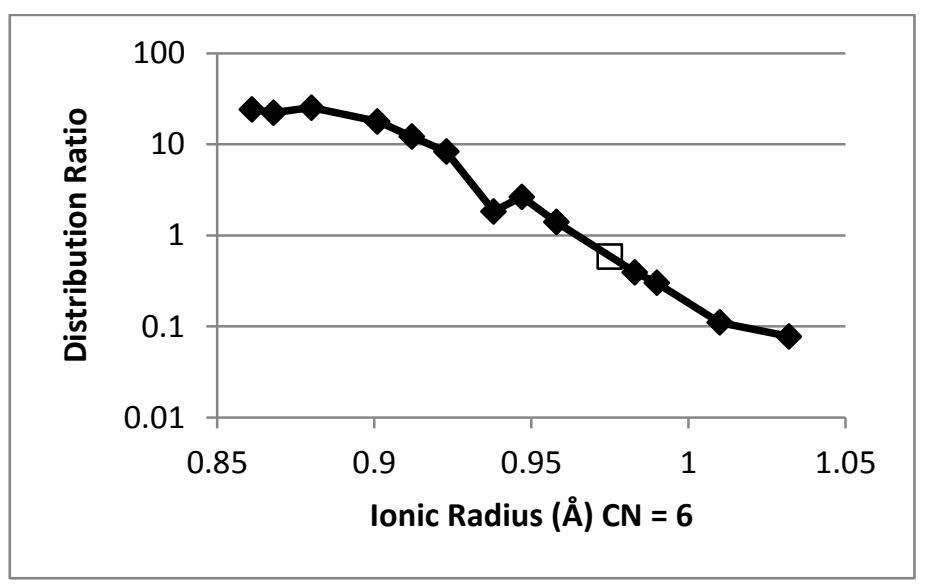

Figure V-3. TBDGA solvent extraction distribution ratios from $1 \mathrm{M} \mathrm{HNO}_{3}$ for the lanthanides and Am (open square) as a function of ionic radius for extractions in 1-octanol.

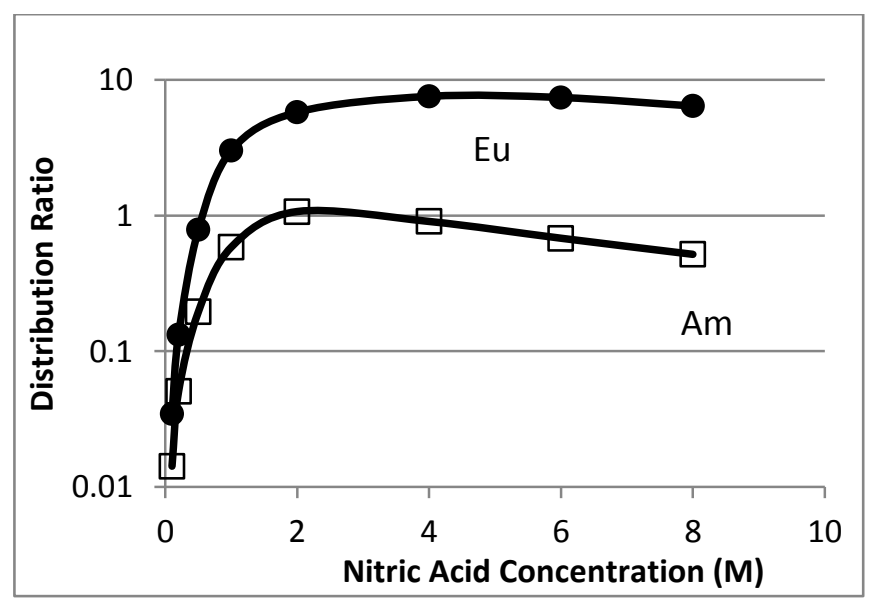

Figure V-4. The solvent extraction of Am (III) and Eu (III) radiotracers from nitric acid solution by $0.007 \mathrm{M}$ TBDGA in 1-octanol.

In the extraction of trivalent lanthanide ions from nitric acid into the ionic liquid $[\mathrm{Bmim}]\left[\mathrm{Tf}_{2} \mathrm{~N}\right]$ with TBDGA, the distribution ratio increases with decreasing ionic radius first, reaches a maximum around $\mathrm{Eu}^{3+}$ and then decreases with the remaining of the lanthanides. The results suggest that ionic liquid extraction systems could be useful for group separation of the trivalent lanthanide ions, especially for the middle lanthanides. The separation factor $\left(\alpha_{\mathrm{Eu} / \mathrm{Am}}\right)$ is small compared with that observed in the octanol extraction system. In both octanol and ionic liquid extraction systems, the nitrate complexes of the metals were extracted, except that neutral complexes were extracted into 1-octanol and ionic complexes extracted into the RTIL. These 
ionic complexes probably were either cations or anions depending on the nitrate concentration in the aqueous phase. It now seems well established that the mechanism of extraction into RTILs is often different than that in molecular solvents, and therefore solvent extraction characteristics need to be reevaluated even for well-known ligands when used in RTIL diluents. The details of the americium and lanthanide partitioning studies are given in an article entitled "The Partitioning of Americium and the Lanthanides Using Tetrabutyldiglycolamide (TBDGA) in Octanol and in Ionic Liquid Solution" which was published recently in Solvent Extraction and Ion Exchange (2012, 30, 735-747). The article is attached in the Appendix.

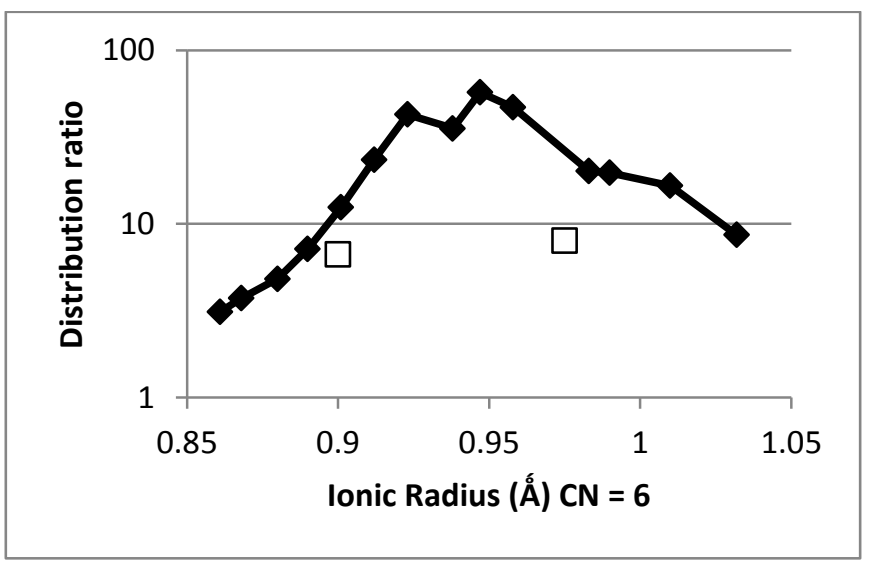

Figure V-5. TBDGA IL extraction distribution ratios from $1 \mathrm{M} \mathrm{HNO}_{3}$ as a function of ionic radius for extractions in $[\mathrm{Bmim}]\left[\mathrm{Tf}_{2} \mathrm{~N}\right]$. The left open square is $\mathrm{Y}$, the right open square is Am.

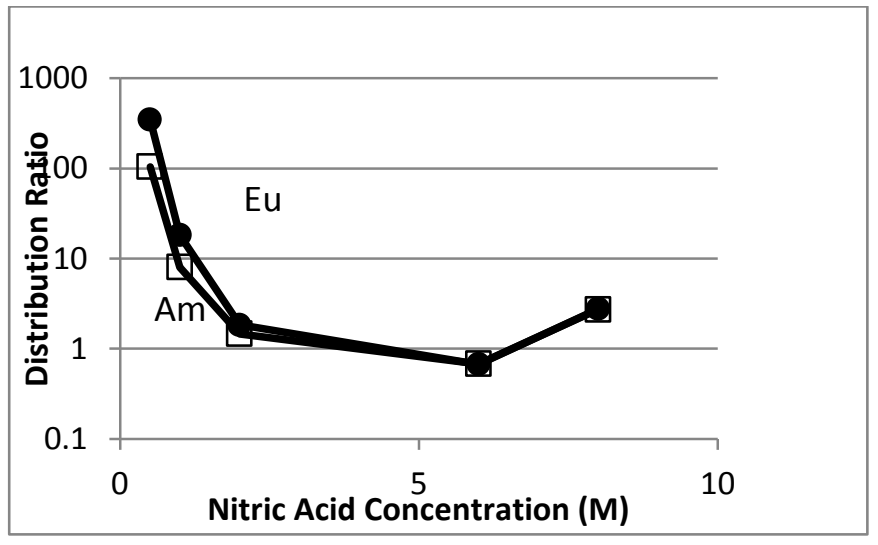

Figure V-6. The extraction of Am and Eu radiotracers from nitric acid solution by $0.007 \mathrm{M}$ TBDGA in $[\mathrm{Bmim}]\left[\mathrm{Tf}_{2} \mathrm{~N}\right]$. 


\section{V-3. Recycling Ionic Liquid for Repeated Use}

Because ionic liquid is expensive, recycling used IL is necessary for economic considerations. This section describes a simple hexane extraction method for recycling used $[\mathrm{Bmim}]\left[\mathrm{Tf}_{2} \mathrm{~N}\right]$ after $\mathrm{UO}_{2}$ dissolution and supercritical fluid extraction experiments. The recycled $[\mathrm{Bmim}]\left[\mathrm{Tf}_{2} \mathrm{~N}\right]$ can be used again for $\mathrm{UO}_{2}$ dissolution without losing its capability.

Our experiments indicate that when $\mathrm{UO}_{2}$ solid is dissolved in $[\mathrm{Bmim}]\left[\mathrm{Tf}_{2} \mathrm{~N}\right]$ containing $\operatorname{TBP}\left(\mathrm{HNO}_{3}\right)_{1.8}\left(\mathrm{H}_{2} \mathrm{O}\right)_{0.6}$, greater than $99 \%$ of the dissolved uranyl species can be recovered by repeated hexane extraction. The distribution ratio of $\mathrm{UO}_{2}\left(\mathrm{NO}_{3}\right)_{2}(\mathrm{TBP})_{2}$ in the hexane phase is estimated to be about 2. The distribution ratio is defined as the molar ratio of uranium in the hexane phase over that in the IL phase with equal volume of the two phases. The color of the IL phase turns from bright yellow to near colorless after 5 times of repeated hexane extractions (Figure V-7A). The ionic liquid phase is then washed with de-ionized water several times to remove remaining $\mathrm{HNO}_{3}$. The $\mathrm{UV}-\mathrm{V}$ is spectrum of the extracted uranyl species in the hexane solution is shown in Figure V-7B. Our previous spectroscopic study indicates that the symmetric stretching band of $\mathrm{UO}_{2}\left(\mathrm{NO}_{3}\right)_{2}(\mathrm{TBP})_{2}$ occurs at $860 \mathrm{~cm}^{-1}$ in Raman spectrum. In Figure V-8A-a, the same vibrational peak at $860 \mathrm{~cm}^{-1}$ is observed when $\mathrm{UO}_{2}$ is dissolved in $[\mathrm{Bmim}]\left[\mathrm{Tf}_{2} \mathrm{~N}\right]$ containing TBP $\left(\mathrm{HNO}_{3}\right)_{1.8}\left(\mathrm{H}_{2} \mathrm{O}\right)_{0.6}$. Figures V-8A-b and $2 \mathrm{~A}-\mathrm{c}$ show the absence of the $860 \mathrm{~cm}^{-1}$ peak for the recycled IL as well as in the commercial $[\mathrm{Bmim}]\left[\mathrm{Tf}_{2} \mathrm{~N}\right]$. In addition, FTIR spectra (Figure V-8B) reveal that when $\mathrm{UO}_{2}$ is dissolved in the IL phase containing $\operatorname{TBP}\left(\mathrm{HNO}_{3}\right)_{1.8}\left(\mathrm{H}_{2} \mathrm{O}\right)_{0.6}$, the peak of IL shows a broad band in the range $925-970 \mathrm{~cm}^{-1}$ (Figure $8 \mathrm{~B}$ a) due to overlapping of $\mathrm{TBP}\left(\mathrm{HNO}_{3}\right)_{1.8}\left(\mathrm{H}_{2} \mathrm{O}\right)_{0.6}$ and uranyl species. Figures V-8B-b and 8B-c show a vibrational peak at about $950 \mathrm{~cm}^{-1}$ for the recycled IL and the commercial IL. The UVVis spectra of $\mathrm{UO}_{2}$ dissolved in $[\mathrm{Bmim}]\left[\mathrm{Tf}_{2} \mathrm{~N}\right]$ containing $\mathrm{TBP}\left(\mathrm{HNO}_{3}\right)_{1.8}\left(\mathrm{H}_{2} \mathrm{O}\right)_{0.6}$ and recycled $[\mathrm{Bmim}]\left[\mathrm{Tf}_{2} \mathrm{~N}\right]$ are shown in Figure V-9A and V-9B, respectively. The uranyl absorption peaks from 380-480 $\mathrm{nm}$ are not visible in the recycled IL. The recycled IL $[\mathrm{Bmim}]\left[\mathrm{Tf}_{2} \mathrm{~N}\right]$ produces the same dissolution results for $\mathrm{UO}_{2}$ and $\mathrm{Nd}_{2} \mathrm{O}_{3}$ with $\mathrm{TBP}\left(\mathrm{HNO}_{3}\right)_{1.8}\left(\mathrm{H}_{2} \mathrm{O}\right)_{0.6}$ and related spectroscopic measurements compared with newly synthesized or commercially available $[\mathrm{Bmim}]\left[\mathrm{Tf}_{2} \mathrm{~N}\right]$. 
(A)

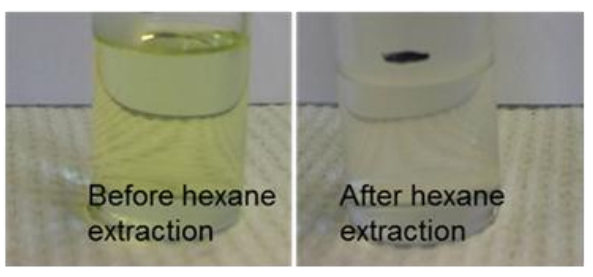

(B)

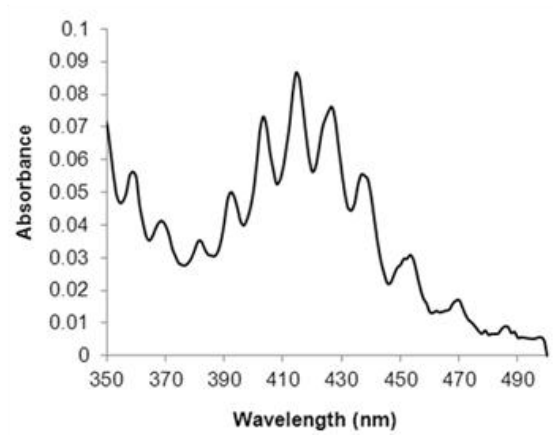

Figure V-7. (A) Picture of the IL solution: before hexane extraction (left) and after hexane extraction (right); (B) UV spectrum of the extracted uranyl species in hexane phase.
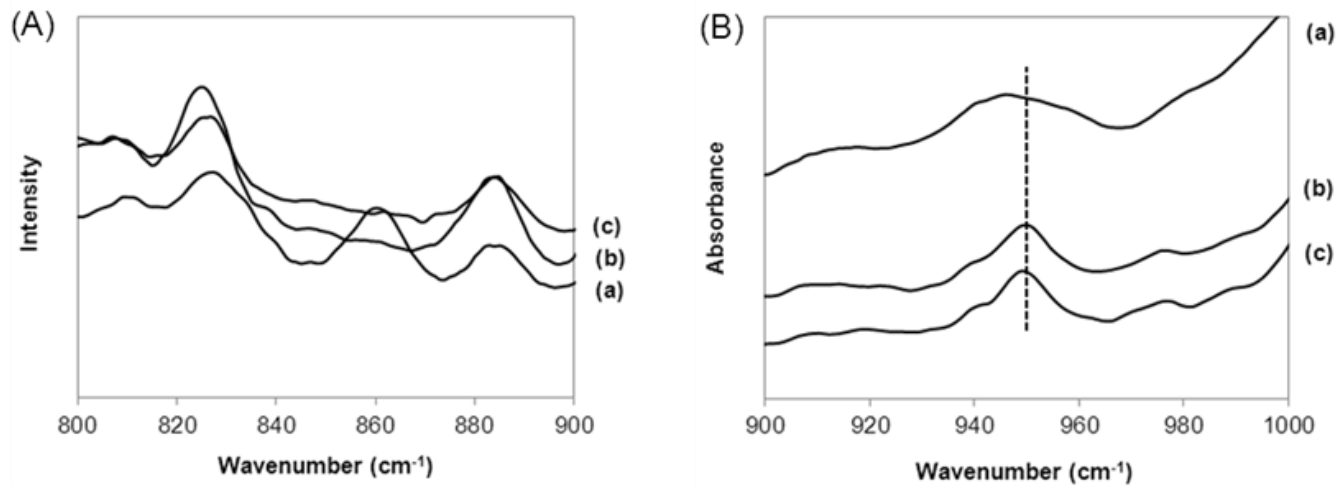

Figure V-8. (A) Raman spectrum (a) the peak at $860 \mathrm{~cm}^{-1}$ for $\mathrm{UO}_{2}$ dissolved in $[\mathrm{Bmim}]\left[\mathrm{Tf}_{2} \mathrm{~N}\right]$ containing TBP $\left(\mathrm{HNO}_{3}\right)_{1.8}\left(\mathrm{H}_{2} \mathrm{O}\right)_{0.6}$, (b) recycle IL showing no detectable $860 \mathrm{~cm}^{-1}$ peak, and (c) commercial IL. (B) IR spectra (a) the broad peak at $941 \mathrm{~cm}^{-1}$ for $\mathrm{UO}_{2}$ dissolved in the IL containing TBP $\left(\mathrm{HNO}_{3}\right)_{1.8}\left(\mathrm{H}_{2} \mathrm{O}\right)_{0.6}$, (b) and (c) the peak at $950 \mathrm{~cm}^{-1}$ for both recycled IL and commercial IL.
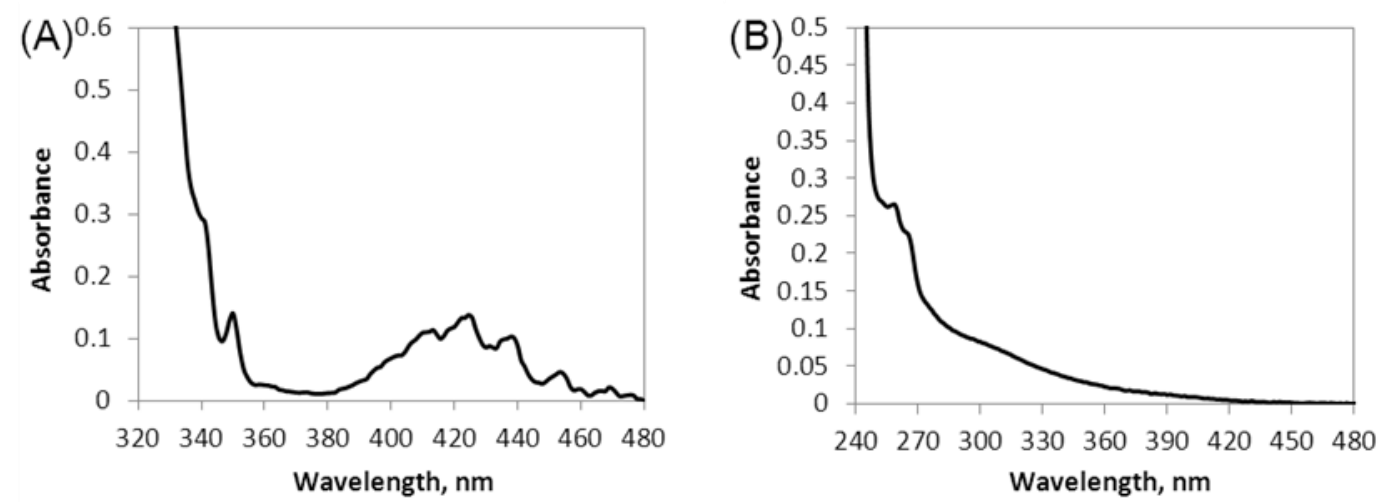

Figure V-9. UV-Vis spectrum of (A) $\mathrm{UO}_{2}$ dissolved in IL containing $\mathrm{TBP}-\mathrm{HNO}_{3}$ complex, (B) recycled $[\mathrm{Bmim}]\left[\mathrm{Tf}_{2} \mathrm{~N}\right]$. 


\section{References}

1. C.M. Wai, "Green Separation Techniques for Nuclear Waste Management" in Nuclear Energy and the Environment, ACS Symposium Series 1046, Ed. B.J. Mincher and C.M. Wai, 2010, American Chemical Society, Washington, DC, Chapter 5, p 53-64.

2. Y. Enokida, O. Tomioka, S.C. Lee, A. Rustenholtz, C.M. Wai, Ind Eng Chem Res 2003, 42, 5037-5041.

3. M.J. Carrott, B.E. Waller, N.G. Smart, C.M. Wai, Chem. Commun. 1998, 373-374.

4. K. Binnemans, Chemical Review 2007, 107, 2592-2614.

5. V.A. Cocalia, K.E. Gutowski and R.D. Rogers, Coord. Chem. Rev., 2006, 250, 755-764.

6. J.S. Wang, C.N. Sheaff, B. Yoon, R.S. Addleman, C.M. Wai, Chem.-Eur. J. 2009, 15, 44584463.

7. I. Billard, C. Gaillard, C. Hennig, Dalton Trans., 2007, 36, 4214-4221.

8. D.L. Quach, C.M. Wai, S.P. Pasilis, Inorganic Chemistry, 2010, 49, 8568-8572.

9. S. Georg, I. Billard, A. Ouadi, C. Gaillard, L. Petitjean, M. Picquet, V. Solov'ev, J. Phys. Chem. B, 2010, 114, 4276-4282.

10. K. Servaes, C. Hennig, I. Billard, C. Gaillard, K. Binnemans, C. Gorller-Walrand, R. Van Deun, Eur. J. Inorg. Chem., 2007, 5120-5126.

11. E.R. Talaty, S. Raja, V.J. Storhaug, A. Dolle, W.R. Carper, J. Phys. Chem. B, 2004, 108, 13177-13184.

12. C. Nguyen-Trung, D.A. Palmer, G.M. Begun, C. Peiffert, R.E. Mesmer, J. Solution Chem., 2000, 29, 101-129.

13. M.H. Brooker, C.H. Huang, J. Sylwestrowicz, J. Inorg. Nucl. Chem., 1980, 42, 1431-1440.

14. C. Gaillard, A. Chaumont, I. Billard, C. Hennig, A. Ouadi, G. Wipff, Inorg. Chem., 2007, 46, 4815-4826.

15. V.A. Cocalia, M.P. Jensen, J.D. Holbrey, S.K. Spear, D. C. Stepinski, R.D. Rogers, Dalton Trans., 2005, 34, 1966-1971.

16. P. Giridhar, K.A. Venkatesan, T.G. Srinivasan, P.R.V. Rao, J. Radioanal. Nucl. Chem., 2005, 265, 31-38. 
18. K. Sawada, K. Uruga, T. Koyama, T. Shimada, Y. Mori, Y. Enokida, I. Yamamoto, J. Nucl. Sci. Technol., 2005, 42, 301-304.

19. Y. Ikeda, Y. Yasuike, K. Nishimura, S. Hasegawa, Y. Takashima, J. Nucl. Mater., 1995, 224, 266-272.

20. R.F. Taylor, E.W. Sharratt, L.E.M.d. Chazal, D.H. Logsdail, J. Appl. Chem., 1963, 13, 32-40.

21. J. A. Widegren, A. Laesecke, J.W. Magee, Chem. Commun., 2005, 1610-1612.

22. H. Luo, S. Dai, P.V. Bonnesen, T.J. Haverlock, B.A. Moyer and A.C. Buchanan, Solvent Extr. Ion Exch., 2006, 24, 19-31.

23. M.G. Freire, P.J. Carvalho, R.L. Gardas, I.M. Marrucho, L.M.N.B.F. Santos, J.A.P. Coutinho, J. Phys. Chem. B, 2008, 112, 1604-1610.

24. K. Shimojo, K. Kurahashi, H. Naganawa, Dalton Trans. 2008, 37, 5083.

25. Y.L. Shen, X.W. Tan, L. Wang, S.W. Wu, Sep. Purif. Technol. 2011, 78, 298.

26. G.X. Tian, W.S. Liao, C.M. Wai, L.F. Rao, Ind. Eng. Chem. Res. 2008, 47(8), 2803.

27. S.P, Pasilis, A. Blumenfeld, Inorg. Chem. 2011, 50, 8302.

28. S. Kannan, M.A. Moody, C.L. Barnes, B.P. Duval, Inorg. Chem. 2008, 47, 4691.

29. A.K. Pyartman, V.A. Keskinov, A.V. Kudrova, Radiochem. 2005, 47, 382.

30. K.D. Bartle, A.A. Clifford, S.A. Jafar, G.F. Shilstone, J. Phys. Chem. Ref. Data 1991, 20, 713.

31. E.A. Mowafy, H.F. Aly, Solvent Extr. Ion Exch. 2007, 25, 205. 


\title{
Appendix
}

\section{Characterization of Uranyl(VI) Nitrate Complexes in a Room Temperature lonic Liquid Using Attenuated Total Reflection-Fourier Transform Infrared Spectrometry}

\author{
Donna L. Quach, Chien M. Wai, and Sofie P. Pasilis* \\ Department of Chemistry, University of Idaho, Moscow, Idaho 83844-2343
}

Received June 15, 2010

\begin{abstract}
Room temperature ionic liquids form potentially important solvents in novel nuclear waste reprocessing methods, and the solvation, speciation, and complexation behaviors of actinides and lanthanides in room temperature ionic liquids is of current interest. In this study, the coordination environment of uranyl(VI) in solutions of the room temperature ionic liquid 1-buty-3-methylimidazolium bis(trifluoromethylsulfonyl) imide containing either tetrabutylammonium nitrate or nitric acid was characterized using attenuated total reflection-Fourier transform infrared spectrometry. Both $\mathrm{UO}_{2}\left(\mathrm{NO}_{3}\right)_{2}$ and $\mathrm{UO}_{2}\left(\mathrm{NO}_{3}\right)_{3}{ }^{-}$species were detected in solutions containing tetrabutylammonium nitrate. $\nu_{\mathrm{as}}\left(\mathrm{UO}_{2}\right)$ for these two species were found to lie at 951 and $944 \mathrm{~cm}^{-1}$, respectively, while $v_{\mathrm{as}}\left(\mathrm{UO}_{2}\right)$ arising from uranyl(V) coordinated by bis(trifluoromethylsulfony)) imide anions in 1-butyl-3-methylimidazolium bis(trifluoromethylsulfonyl) imide was found to lie at $968 \mathrm{~cm}^{-1}$. In solutions containing nitric acid, only $\mathrm{UO}_{2}\left(\mathrm{NO}_{3}\right)_{2}$ was detected, due to the high wate content. The $\mathrm{UO}_{2}\left(\mathrm{NO}_{3}\right)^{+}$species was not detected under the conditions used in this study. From the results shown here, we conclude that infrared spectroscopy forms a valuable addition to the suite of tools currently used to study the chemical behavior of uranyl(VI) in room temperature ionic liquids.
\end{abstract}

\section{Introduction}

Reprocessing of spent nuclear fuel with recycling of fissile isotopes is necessary to optimize energy extraction from actinide resources and to minimize waste product production. A number of solvent extraction processes have been used in order to separate plutonium and uranium from fission products in spent nuclear fuel, with the most widely used process being the plutonium and uranium recovery by extraction (PUREX) process. ${ }^{1}$ In the PUREX process, tri- $n$ butylphosphate (TBP) is dissolved in a paraffinic hydrocarbon and used to extract uranium and plutonium from nitric acid solutions, thus allowing the recovery of these elements from fission products. ${ }^{2}$ This technique requires the use of potentially hazardous organic solvents with relatively high disposal costs. Separations processes that can safely and effectively separate the useful components of discharged nuclear fuel from the wastes, while dramatically reducing their volume and toxicity, a re currently being developed. ${ }^{3,4} \mathrm{~A}$ new three-step extraction technique for the extraction of actinides and lanthanides from a solid or an aqueous phase

\footnotetext{
*To whom correspondence should be addressed. E-mail: spasilis@ uidaho.edu. Phone: 208-885-4014. Fax: 208-885-6173.

(1) Choppin, G. R. Solvent Extr. Res. Dev., Jpn. 2005, $12,1$.

(2) McKibben, J. M. Radiochim. Acta 1984, 36, 3

(3) Mekki, S.; Wai, C. M.; Billard, I.; Moutiers, G.; Burt, J.; Yoon, B.; Wang, J. S.; Gaillard, C;; Ouadi, A.; Hesemann, P. Chem-Eur. J. 2006, I2, 1760.

(4) Wang, J. S.; Sheaff, C. N.; Yoon, B.; Addleman, R. S.; Wai, C. M. Chem-Eur.J. 2009, 15, 4458.
}

into a room temperature ionic liquid (RTIL) phase and then from the RTIL phase into a supercritical $\mathrm{CO}_{2}\left(\mathrm{sc}-\mathrm{CO}_{2}\right)$ phase has been proposed as an alternative "green" technology for nuclear waste treatment, because the physical and chemical properties of RTILs and sc- $\mathrm{CO}_{2}$ make them attractive replacements for volatile organic solvents. ${ }^{3,4} \mathrm{New}$, greener separations methods are needed to help improve public acceptance of nuclear power.

Extractions of actinides and lanthanides into RTILs and $\mathrm{sc}-\mathrm{CO}_{2}$ are still in the initial stages of development and little is known about the extraction mechanisms at work in these solvents. In order to gain insight in to extraction mechanisms and optimize extraction efficiencies for the different radionuclide species, it is important to understand the solvation, speciation, and complexation behaviors of actinides and lanthanides in RTILs, sc-CO $\mathrm{CO}_{2}$, and RTIL/sc-CO mixtures. While the chemistry of actinides and lanthanides in sc- $\mathrm{CO}_{2}$ has been little studied, there is currently a great deal of interest in the speciation and coordination chemistry of actinides and lanthanides in RTIL, and several review articles have recently been published on this topic. ${ }^{5-7}$ To date, the bulk of the spectroscopic studies on uranium complexes in RTIL has been completed using UV-visible spectrophotometry and/or extended X-ray absorption fine structure (EXAFS) spectroscopy. However, vibrational spectroscopy

(5) Cocalia, V. A.; Gutowski, K. E.; Rogers, R. D. Coord. Chem. Rev. 2006, 250,755

(6) Bimemans, K. Chem. Rev. 2007, 107, 2592

(7) Billard, I.; Gaillard, C. Radiochim. Acta 2009, 97, 355. 
can also provide important information regarding uranyl(VI) complexation and coordination in solution and has been extensively used for that purpose. ${ }^{8-16}$ The Raman active $v_{\mathrm{s}}\left(\mathrm{UO}_{2}\right)$ mode and the infrared active $v_{\text {as }}\left(\mathrm{UO}_{2}\right)$ mode are sensitive to changes in the uranyl(VI) coordination environment. Complexation of uranyl(VI) weakens the $\mathrm{O}=\mathrm{U}=\mathrm{O}$ bonds, causing $v_{\mathrm{s}}\left(\mathrm{UO}_{2}\right)$ and $v_{\mathrm{as}}\left(\mathrm{UO}_{2}\right)$ to shift to lower wavenumbers. The extent of this shift can be correlated to the complex formed and can be used to track uranyl(VI) speciation in solution. In this study, we use attenuated total reflection-Fourier transform infrared spectrometry to characterize the complexes formed in solutions of the RTIL 1-butyl-3-methylimidazolium bis(trifluoromethylsulfonyl)imide ([BMIM][Tf $2 \mathrm{~N}]$ ) containing uranyl(VI) and either tetrabutylammonium nitrate (TBAN) or $\mathrm{HNO}_{3}$.

\section{Experimental Section}

Chemicals and Reagents. Uranium trioxide, $\mathrm{UO}_{3}$, and uranyl nitrate hexahydrate, $\mathrm{UO}_{2}\left(\mathrm{NO}_{3}\right)_{2} \cdot 6 \mathrm{H}_{2} \mathrm{O}$, were purchased from International Bio-Analytical Industries, Inc. (Boca Raton, FL) Concentrated nitric acid ( $70 \% \mathrm{w} / \mathrm{w})$, tri- $n$-butylphosphate (TBP), 1-butyl-3-methylimidazolium chloride, [BMIM]Cl, and lithium bis(trifluoromethane) sulfonimide, $\left[\mathrm{LiN}\left(\mathrm{CF}_{3} \mathrm{SO}_{2}\right)_{2}\right]$ were purchased from Sigma-Aldrich (Milwaukee, WI). Acetonitrile and methylene chloride were purchased from Fisher Scientific (Pittsburgh, PA). Toluene was purchased from EMD Chemicals Inc. (Gibbstown, NJ). Deuterated chloroform $(99.8 \% \mathrm{D})$ and $\mathrm{D}_{2} \mathrm{O}$ $(99.9 \% \mathrm{D})$ were purchased from Cambridge Isotope Laboratories, Inc. (Andover, MA).

Instruments. A Bruker Avance $500 \mathrm{MHz}$ NMR spectrometer

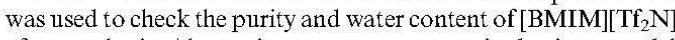
after synthesis. Absorption spectra were acquired using a model $440 \mathrm{UV}$-visible spectrophotometer with a CCD array detector (Spectral Instruments Inc., Tucson AZ). ATR-FTIR spectra were acquired using a Nicolet Magna 760 FTIR spectrometer equipped with a DTGS detector. ATR-FTIR measurements were made with a SplitPea attenuated total reflection accessory (Harrick Scientific Corporation). A silicon internal reflection element was used as a reflection medium. Silicon is relatively inert and resistant to corrosive materials, while zinc selenide is not compatible with acids and strong bases, and germanium is soluble in nitric acid. ATR-FTIR spectra were acquired using 500 coadded scans at $2 \mathrm{~cm}^{-1}$ resolution with Happ-Genzel apodization. A single-beam reference spectrum of the silicon ATR internal reflection element was acquired at the start of each experiment, and each single-beam sample spectrum collected was ratioed against this background reference spectrum. Spectra were not otherwise corrected. Each sample spect rum required $\sim 17 \mathrm{~min}$ to collect.

Synthesis of 1-Butyl-3-methylimidazolium Bis(trifluoromethyl-

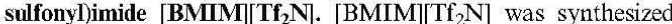
from the metathesis of [BMIM] Cl and [ $\left.\mathrm{LiN}\left(\mathrm{CF}_{3} \mathrm{SO}_{2}\right)_{2}\right]$ following an established literature procedure. ${ }^{3}$ The resulting ionic liquid was washed and extracted with dichloromethane and deionized water.

(8) Brooker, M. H.; Huang, C.-H.; Sylwestrowicz, J. J. Inorg. Nucl. Chem. 1980, 42, 1431

(9) Toth, L. M.; Begun, G. M. J. Phys. Chem. 1981, 85, 547

(10) Gal, M.; Goggin, P. L.; Mink, J. Spectrochim Acta 1992, 48 A, 121 (11) Nguyen-Trung, C.; Begun, G. M.; Palmer, D. A. Inorg. Chem. 1992 31,5280 .

(12) Quiles, F.; Burneau, A. Vib. Spectrosc. 1998, 18, 61.

(13) Quiles, F.; Burneau, A. Vib. Spectrosc. 2000, 23, 231

(14) Nguyen-Trung, C.; Palmer, D. A.; Begun, G. M.; Peiffert, C.; Mesmer, R. E. J. Solution Chem. 2000, 29, 101.

(15) Pasilis, S. P.; Pemberton, J. E. Inorg. Chem. 2003, 42, 6793.

(16) Muller, K.; Brendler, V.; Foerstendorf, H. Inorg. Chem. 2008, 47, 10127
The excess dichloromethane was removed by evaporation under reduced pressure using a rotary evaporator. The sample was left under vacuum overnight at $68^{\circ} \mathrm{C}$ to remove excess water. The purity and water content of the ionic liquid were evaluated using ${ }^{1} \mathrm{H}$ NMR, and the chloride content was determined by neutron activation analysis at the Washington State University (Pullman, WA) Nuclear Radiation Center. The water concentration was determined as follows: a known volume and mass of [BMIM]$\left[\mathrm{Tf}_{2} \mathrm{~N}\right]$ was placed in a $5 \mathrm{~mm}$ diameter NMR tube. An insert containing $66 \mu \mathrm{L}$ of $99.9 \% \mathrm{D}_{2} \mathrm{O}$ was placed in the NMR tube with the sample, and a ${ }^{1} \mathrm{H}$ NMR spectrum was acquired. Residual $\mathrm{HDO}$ (chemical shift $4.74 \mathrm{ppm}$ ) arising from the $\mathrm{D}_{2} \mathrm{O}$ in the insert was used as a reference. Water in the [BMIM] $\left[\mathrm{Tf}_{2} \mathrm{~N}\right]$ sample gave rise to a ${ }^{1} \mathrm{H}$ NMR signal at $2.38 \mathrm{ppm}$. This signal $\left(I_{\mathrm{H} 2 \mathrm{O}}\right)$ was integrated and compared to the integrated signal of a butyl chain $\mathrm{CH}_{2}$ proton triplet $\left(I_{\mathrm{CH}}, 1.8 \mathrm{ppm}\right)$. The number of water protons $\left(n_{\mathrm{H} 2 \mathrm{O}}\right)$ could be calculated using the relationship $n_{\mathrm{H} 2 \mathrm{O}} / n_{\mathrm{CH} 2}=$ $I_{\mathrm{H} 2 \mathrm{O}} / I_{\mathrm{CH} 2}$. The number of protons giving rise to the $\mathrm{CH}_{2}$ proton triplet $\left(n_{\mathrm{CH} 2}\right)$ was calculated using the sample mass and molecular weight, and, since the sample volume was also known, the concentration of water in the sample could be determined. The concentration of water in the final product was $10 \mathrm{mM}$, while the chloride concentration was $0.008 \mathrm{mM}$.

Synthesis of Uranyl(VI) Bis (trifluoromethylsulfonyl)imide. Uranyl(VI) bis(trifluoromethylsulfonyl)imide $\left(\mathrm{UO}_{2}\left(\mathrm{Tf}_{2} \mathrm{~N}_{2} \cdot x \mathrm{H}_{2} \mathrm{O}\right)\right.$ was synthesized according to the method of Nockemann et al. ${ }^{17}$ The synthesis began with the conversion of lithium bis(trifluoromethylsulfonyl)imide ( $2 \mathrm{M})$ into the corresponding acid, $\mathrm{H}\left(\mathrm{Tf}_{2} \mathrm{~N}\right)$, with the addition of excess $20 \% \mathrm{H}_{2} \mathrm{SO}_{4}$. In the process of converting the salt into an acid, lithium sulfate was produced. The desired acid was extracted with diethyl ether and washed with water to remove trace amounts of lithium sulfate. Evaporation of diethyl ether under reduced pressure using a rotary evaporator gave $\mathrm{H}\left(\mathrm{Tf}_{2} \mathrm{~N}\right)$. In the next step, uranium(VI) oxide $(0.023 \mathrm{~mol})$ was suspended in water in a round-bottom flask, and a small excess of $\mathrm{H}\left(\mathrm{Tf}_{2} \mathrm{~N}\right)(0.033 \mathrm{~mol})$ was added. This mixture was allowed to react for 3 days at $50^{\circ} \mathrm{C}$ with stirring, following which the temperature was increased to $75{ }^{\circ} \mathrm{C}$ for an additional $24 \mathrm{~h}$. Water was removed under reduced pressure, and a viscous yellow product was obtained. This product was washed with dichloromethane to remove unreacted $\mathrm{H}\left(\mathrm{Tf}_{2} \mathrm{~N}\right)$, then dissolved in methanol, and stirred for $1 \mathrm{~h}$. Unreacted $\mathrm{UO}_{3}$ was filtered off, giving a clear yellow solution. Excess methanol was removed under reduced pressure using a rotary evaporator, leaving a viscous dark yellow substance. The sample was left under vacuum overnight for further solvent removal. The final product was stored in a desiccator.

Sample Preparation. Samples were prepared by dissolving uranyl(VI) nitrate hexahydrate and uranyl(VI) bis(trifluoromethylsulfonyl)imide in [BMIM] $\left[\mathrm{Tf}_{2} \mathrm{~N}\right]$ to a final concentration of $0.1 \mathrm{M}$. Nitrate was added in the form of TBAN or concentrated $\mathrm{HNO}_{3}$. Nitrate concentrations ranged from 0.05 to $0.5 \mathrm{M}$ in $[B M I M]\left[\mathrm{Tf}_{2} \mathrm{~N}\right]$. The samples were sonicated to completely homogenize all solutes in the ionic liquid. A small droplet of sample was placed directly on the silicon internal reflection element prior to analysis by ATR-FTIR. Samples were exposed to the atmosphere during analysis. In order to evaluate the extent of water uptake from the atmosphere, a sample of $[\mathrm{BMIM}]\left[\mathrm{Tf}_{2} \mathrm{~N}\right]$ was placed on the internal reflection element, and water $v_{\mathrm{s}}(\mathrm{OH})$ modes at 3636 and $3565 \mathrm{~cm}^{-1}$ were monitored over the course of $17 \mathrm{~min}$, the time required to collect a typical spectrum. No increase was seen in the intensities of these modes during this time, indicating little water is absorbed from the atmosphere during spectral acquisition under our laboratory conditions.

(17) Nockemann, P.; Servaes, K.; Van Deun, R.; Van Hecke, K.; Van Meervelt, L.; Binnemans, K.; Goerller-Walrand, C. Inorg. Chem. 2007, 46, 11335 . 
8570 Inorganic Chemistry, Vol. 49, №. 18, 2010

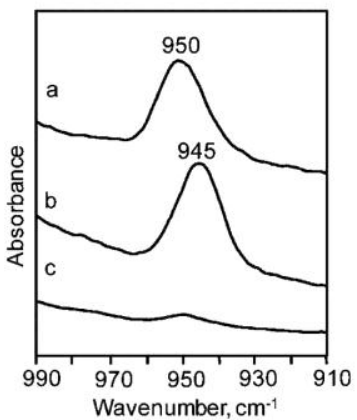

Figure 1. ATR-FTIR spectra showing the $v_{\text {as }}\left(\mathrm{UO}_{2}\right)$ region for solutions of $[\mathrm{BMIM}]\left[\mathrm{Tf}_{2} \mathrm{~N}\right]$ containing (a) $0.1 \mathrm{M} \mathrm{UO}_{2}\left(\mathrm{NO}_{3}\right)_{2} \cdot 6 \mathrm{H}_{2} \mathrm{O}$, (b) $0.1 \mathrm{M}$ $\mathrm{UO}_{2}\left(\mathrm{NO}_{3}\right)_{2} \cdot 6 \mathrm{H}_{2} \mathrm{O}$ with $0.1 \mathrm{M}$ TBAN, and (c) $0.1 \mathrm{M}$ TBAN.

\section{Results and Discussion}

The effect of changing uranyl(VI) coordination environment on $v_{\text {as }}\left(\mathrm{UO}_{2}\right)$ is illustrated in the infrared spectra shown in Figure 1a,b. Figure 1a shows a spectrum acquired from a solution of $0.1 \mathrm{M}$ uranyl nitrate hexahydrate dissolved in $[\mathrm{BMIM}]\left[\mathrm{Tf}_{2} \mathrm{~N}\right]$, while Figure $1 \mathrm{~b}$ shows a spectrum acquired from a $0.1 \mathrm{M}$ solution of uranyl nitrate hexahydrate in [BMIM] $\left[\mathrm{Tf}_{2} \mathrm{~N}\right]$ to which $0.1 \mathrm{M}$ TBAN had been added. Figure 1c shows a spectrum acquired from a $0.1 \mathrm{M}$ solution of TBAN. TBAN does not have any significant vibrational modes in the $v_{\text {as }}\left(\mathrm{UO}_{2}\right)$ region. When uranyl nitrate hexahydrate is dissolved in [BMIM] $\left[\mathrm{Tf}_{2} \mathrm{~N}\right]$, a complex is formed having $v_{\text {as }}\left(\mathrm{UO}_{2}\right)$ at $950 \mathrm{~cm}^{-1}$, as shown in Figure la. With the addition of nitrate in the form of TBAN, such that the total concentration of nitrate in solution is $0.3 \mathrm{M}$, the uranyl(VI) coordination environment is changed and $v_{\text {as }}\left(\mathrm{UO}_{2}\right)$ is shifted to $945 \mathrm{~cm}^{-1}$ (Figure 1b). Previous work using UV-visible spectrophotometry and EXAFS to examine uranyl(VI) nitrate complexes formed in RTIL has indicated that the major species are $\mathrm{UO}_{2}\left(\mathrm{NO}_{3}\right)^{+}, \mathrm{UO}_{2}\left(\mathrm{NO}_{3}\right)_{2}$, and $\mathrm{UO}_{2}\left(\mathrm{NO}_{3}\right)_{3}{ }^{-17-20}$ Servaes et al. ${ }^{19}$ and Georg et ll. $^{20}$ have shown that $\mathrm{UO}_{2}\left(\mathrm{NO}_{3}\right)_{3}{ }^{-}$is the major species in RTIL solutions when nitrate is present in excess. Thus, we assign the mode at $945 \mathrm{~cm}^{-1}$ (Figure 1 b) to $\mathrm{UO}_{2}\left(\mathrm{NO}_{3}\right)_{3}{ }^{-}$. The mode at $950 \mathrm{~cm}^{-1}$ can then be assigned to the dinitrato complex, $\mathrm{UO}_{2}\left(\mathrm{NO}_{3}\right)_{2}$ (Figure 1a). The formation of the two uranyl(VI) nitrate complexes may also be followed through the growth of a $v(\mathrm{NO})$ mode at $1537 \mathrm{~cm}^{-1}$ (Figure 2a,b). This mode is diagnostic for nitrate that is coordinated to a metal ion ${ }^{21}$ and offers further evidence that nitrate forms a complex with uranyl(VI) in [BMIM] $\left[\mathrm{Tf}_{2} \mathrm{~N}\right]$. The $v(\mathrm{NO})$ mode increases in intensity when TBAN is added to the solution (Figure 2b). Figure $2 \mathrm{c}$ simply shows a solution of $[\mathrm{BMIM}]\left[\mathrm{Tf}_{2} \mathrm{~N}\right]$ to which TBAN has been added. TBAN does not have vibrational modes in the $v(\mathrm{NO})$ region.

To more easily detect any uranyl(VI) nitrate complexes formed, $\mathrm{UO}_{2}\left(\mathrm{Tf}_{2} \mathrm{~N}\right)_{2}$ was used as a source of uranyl(VI). The

(18) Gaillard, C.; Chaumont, A.; Billard, I.; Hennig, C.; Ouadi, A.; Wipff, G. Inorg. Chem. 2007, 46, 4815.

(19) Servaes, K.: Hennig, C.; Billard, I.; Gaillard, C.; Binnemans, K.; Gorller-Walrand, C.; Van Deun, R. Eur. J. Inorg. Chem. 2007, 5120.

(20) Georg, S.; Billard, I.; Ouadi, A.; Gaillard, C.; Petitjean, L.; Picquet,
(20) M.; Solov'ev, V. J. Phys. Chem. B 2010, 114, 4276.

(21) Nakamoto, K. Infrared and Raman Spectra of Inorganic and Coordination Compounds, 4th ed.; John Wiley \& Sons: New York, 1986.

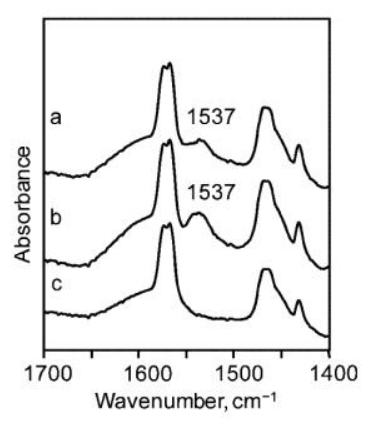

Figure 2. ATR-FTIR spectra showing the $v(\mathrm{NO})$ region for solutions of [BMIM] $\mathrm{Tf}_{2} \mathrm{~N}$ ] containing (a) $0.1 \mathrm{M} \mathrm{UO}_{2}\left(\mathrm{NO}_{3}\right)_{2} \cdot 6 \mathrm{H}_{2} \mathrm{O}$, (b) $0.1 \mathrm{M}$ $\mathrm{UO}_{2}\left(\mathrm{NO}_{3}\right)_{2} \cdot 6 \mathrm{H}_{2} \mathrm{O}$ with $0.1 \mathrm{M}$ TBAN, and (c) $0.1 \mathrm{M}$ TBAN.

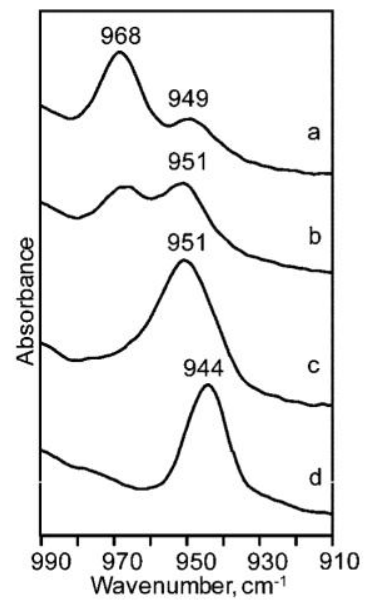

Figure 3. ATR-FTIR spectra showing the $v_{\mathrm{as}}\left(\mathrm{UO}_{2}\right)$ region for solutions of $0.1 \mathrm{M} \mathrm{UO}_{2}\left(\mathrm{Tf}_{2} \mathrm{~N}\right)_{2}$ in [BMIM] $\left[\mathrm{Tf}_{2} \mathrm{~N}\right]$ containing (a) no TBAN, (b) 0.1 M TBAN, (c) $0.2 \mathrm{M}$ TBAN, and (d) $0.3 \mathrm{M}$ TBAN.

bis(trifluoromethylsulfonyl)imide anion is easily displaced by nitrate. ${ }^{18,20}$ In order to track uranyl(VI) speciation in the presence of nitrate, the molar ratio of uranyl(VI) to TBAN was systematically varied and the infrared spectra acquired. The spectra are shown in Figure $3 \mathrm{a}-\mathrm{d}$. When $\mathrm{UO}_{2}\left(\mathrm{Tf}_{2} \mathrm{~N}\right)_{2}$ is dissolved in [BMIM] $\left[\mathrm{Tf}_{2} \mathrm{~N}\right]$, the $v_{\text {as }}\left(\mathrm{UO}_{2}\right)$ mode appears at $968 \mathrm{~cm}^{-1}$ (Figure 3a). This mode can be assigned to uranyl(VI) coordinated by $\mathrm{Tf}_{2} \mathrm{~N}^{-}$anions. A small peak at $\sim 950 \mathrm{~cm}^{-1}$ arises from [BMIM] $\left.\mathrm{Tf}_{2} \mathrm{~N}\right]$. With the addition of $0.1 \mathrm{M}$ TBAN, the $v_{\mathrm{as}}\left(\mathrm{UO}_{2}\right)$ mode at $968 \mathrm{~cm}^{-1}$ decreases in intensity, while a new $v_{\text {as }}\left(\mathrm{UO}_{2}\right)$ mode begins to grow in at $951 \mathrm{~cm}^{-1}$, indicating that a uranyl(VI) nitrate complex has formed in solution (Figure $3 \mathrm{~b}$ ). When the solution TBAN concentration is increased to $0.2 \mathrm{M}$, the intensity of the $v_{\text {as }}\left(\mathrm{UO}_{2}\right)$ mode at $951 \mathrm{~cm}^{-1}$ also increases, while the $v_{\text {as }}\left(\mathrm{UO}_{2}\right)$ mode at $968 \mathrm{~cm}^{-1}$ disappears completely (Figure 3c). The uranyl(VI) nitrate complex formed may be assigned to a $\mathrm{UO}_{2}\left(\mathrm{NO}_{3}\right)_{2}$ species, based on the peak position of $v_{\mathrm{as}}\left(\mathrm{UO}_{2}\right)$ for uranyl nitrate hexahydrate dissolved in [BMIM] $\left[\mathrm{Tf}_{2} \mathrm{~N}\right.$ ]

(22) Kaplan, L.; Hildebrandt, R. A.; Ader, M. J. Inorg. Nucl. Chem. 1956 2,153 . 


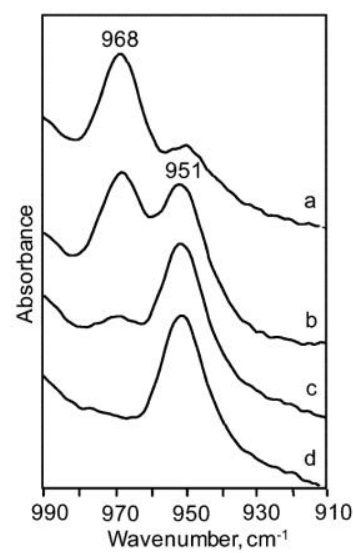

Figure 4. ATR-FTIR spectra showing the $v_{\text {as }}\left(\mathrm{UO}_{2}\right)$ region for solutions of $0.1 \mathrm{M} \mathrm{UO}_{2}\left(\mathrm{Tf}_{2} \mathrm{~N}\right)_{2}$ in [BMIM] $\left[\mathrm{Tf}_{2} \mathrm{~N}\right]$ containing (a) no $\mathrm{HNO}_{3}$, (b) 0.1 $\mathrm{M} \mathrm{HNO}_{3}$, (c) $0.2 \mathrm{M} \mathrm{HNO}_{3}$, and (d) $0.3 \mathrm{M} \mathrm{HNO}_{3}$.
Hon

(Figure 1a). Upon addition of a third aliquot of TBAN, such that the total nitrate concentration in solution is $0.3 \mathrm{M}$, the $v_{\text {as }}\left(\mathrm{UO}_{2}\right)$ mode shifts to $944 \mathrm{~cm}^{-1}$ (Figure 3d). This shift in $v_{\text {as }}\left(\mathrm{UO}_{2}\right)$ represents the formation of the $\mathrm{UO}_{2}\left(\mathrm{NO}_{3}\right)_{3}{ }^{-}$complex. In our study, the absorption bands diagnostic for $\mathrm{UO}_{2}\left(\mathrm{NO}_{3}\right)_{3}{ }^{-22,23}$ can be seen in a UV-visible absorption spectrum acquired from this solution (Supporting Information, Figure 1). These bands can also be seen, albeit at a lower intensity, in a UV-visible absorption spectrum acquired from the solution of $0.1 \mathrm{M} \mathrm{UO}_{2}\left(\mathrm{Tf}_{2} \mathrm{~N}\right)_{2}$ in [BMIM] $\left[\mathrm{Tf}_{2} \mathrm{~N}\right.$ ] containing $0.2 \mathrm{M}$ TBAN, indicating that some $\mathrm{UO}_{2}\left(\mathrm{NO}_{3}\right)_{3}$ is present there as well, (Supporting Information, Figure 1). On the basis of the presence of these characteristic absorption bands for $\mathrm{UO}_{2}\left(\mathrm{NO}_{3}\right)_{3}{ }^{-}$in a solution prepared by dissolution of uranyl nitrate hexahydrate in [BMIM] $\left.\mathrm{Tf}_{2} \mathrm{~N}\right]$, Gaillard et al. ${ }^{18}$ have suggested that $\mathrm{UO}_{2}\left(\mathrm{NO}_{3}\right)_{2}$ can dissociate into $\mathrm{UO}_{2}\left(\mathrm{NO}_{3}\right)^{+}$and $\mathrm{UO}_{2}\left(\mathrm{NO}_{3}\right)_{3}{ }^{-}$. In our ATR-FTIR spectra, the diagnostic mode for $\mathrm{UO}_{2}\left(\mathrm{NO}_{3}\right)_{2}\left(v_{\mathrm{as}}\left(\mathrm{UO}_{2}\right) 951 \mathrm{~cm}^{-1}\right)$ is rather broad and may include a small component at $944 \mathrm{~cm}^{-1}$. Interestingly, the infrared spectra show no evidence for a $v_{\text {as }}\left(\mathrm{UO}_{2}\right)$ mode that could be assigned to the $\mathrm{UO}_{2}\left(\mathrm{NO}_{3}\right)^{+}$species; however, as the $v_{\text {as }}\left(\mathrm{UO}_{2}\right)$ modes are relatively broad, it is possible that a small mode between $v_{\text {as }}\left(\mathrm{UO}_{2}\right) 968 \mathrm{~cm}^{-1}$ and $v_{\text {as }}\left(\mathrm{UO}_{2}\right)$ at $951 \mathrm{~cm}^{-1}$ would not be detected. As in the case for the uranyl nitrate hexahydrate/ TBAN system discussed earlier, the presence of a $v(\mathrm{NO})$ mode at $1536 \mathrm{~cm}^{-1}$ indicates that nitrate is indeed complexed to uranyl(VI) (Supporting Information, Figure 2).

In the three-step extraction method for actinides and lanthanides mentioned above, uranium dioxide is first dissolved in a RTIL containing a mixture of $\mathrm{HNO}_{3}$ and tributyl phosphate and the resulting uranyl complex is then extracted into sc- $\mathrm{CO}_{2}$. Thus, it is of interest to examine the uranyl complexes formed when $\mathrm{HNO}_{3}$ is used as a nitrate source instead of TBAN. Figure $4 a-d$ shows a series of infrared spectra acquired from solutions of $0.1 \mathrm{M} \mathrm{UO}_{2}\left(\mathrm{Tf}_{2} \mathrm{~N}\right)_{2}$ in $[\mathrm{BMIM}]\left[\mathrm{Tf}_{2} \mathrm{~N}\right]$ to which varying amounts of $\mathrm{HNO}_{3}$ have been added. $v_{\text {as }}\left(\mathrm{UO}_{2}\right)$ for a solution $0.1 \mathrm{M}$ in $\mathrm{UO}_{2}\left(\mathrm{Tf}_{2} \mathrm{~N}\right)_{2}$ in

(23) Billard, I.; Gaillard, C.; Hennig, C. Dalton Trans. 2007, 4214.
$[\mathrm{BMIM}]\left[\mathrm{Tf}_{2} \mathrm{~N}\right]$ in the absence of any $\mathrm{HNO}_{3}$ appears at $968 \mathrm{~cm}^{-1}$, assigned above to uranyl(VI) coordinated by $\mathrm{Tf}_{2} \mathrm{~N}^{-}$anions (Figure 3a). When $\mathrm{HNO}_{3}$ is added to the solution such that its final concentration is $0.1 \mathrm{M}$, the $v_{\text {as }}\left(\mathrm{UO}_{2}\right)$ mode at $968 \mathrm{~cm}^{-1}$ decreases in intensity as a new uranyl(VI) nitrate complex having $v_{\text {as }}\left(\mathrm{UO}_{2}\right)$ at $951 \mathrm{~cm}^{-1}$ forms (Figure 4b). $v_{\text {as }}\left(\mathrm{UO}_{2}\right)$ at $968 \mathrm{~cm}^{-1}$ disappears almost completely when the concentration of $\mathrm{HNO}_{3}$ is increased to $0.2 \mathrm{M}$ (Figure 4c). The $v_{\mathrm{as}}\left(\mathrm{UO}_{2}\right)$ mode at $951 \mathrm{~cm}^{-1}$ can be assigned to the $\mathrm{UO}_{2}\left(\mathrm{NO}_{3}\right)_{2}$ species. However, no new $v_{\text {as }}\left(\mathrm{UO}_{2}\right)$ modes are detected in the infrared spectra when the concentration of $\mathrm{HNO}_{3}$ is increased beyond $0.2 \mathrm{M}$. The characteristic trinitrato absorption bands ${ }^{22,23}$ can be clearly seen in the UV-visible absorption spectra of a solution $0.3 \mathrm{M}$ in $\mathrm{HNO}_{3}$, indicating that some $\mathrm{UO}_{2}\left(\mathrm{NO}_{3}\right)_{3}{ }^{-}$is indeed present (Supporting Information, Figure 3). However, the $\mathrm{UO}_{2}\left(\mathrm{NO}_{3}\right)_{3}{ }^{-}$anion is not a major species, existing at concentrations which cannot be detected using infrared spectroscopy under the experimental conditions used for this study.

As was the case in the TBAN/[BMIM] $\left[\mathrm{Tf}_{2} \mathrm{~N}\right]$ system, the $v(\mathrm{NO})$ mode at $1536 \mathrm{~cm}^{-1}$ appears to grow as the concentration of $\mathrm{HNO}_{3}$ increases, indicating that nitrate is coordinated to uranyl(VI) (Supporting Information, Figure 4). The $v_{\text {as }}\left(\mathrm{NO}_{2}\right)$ stretching mode can be seen at $1670 \mathrm{~cm}^{-1}$ when $\mathrm{HNO}_{3}$ concentrations reach $0.2 \mathrm{M}$ (Supporting Information, Figure $4 b, c)$.

A major difference between the TBAN/[BMIM] $\left[\mathrm{Tf}_{2} \mathrm{~N}\right]$ and the $\mathrm{HNO}_{3} /[\mathrm{BMIM}]\left[\mathrm{Tf}_{2} \mathrm{~N}\right]$ systems is that the amount of $\mathrm{H}_{2} \mathrm{O}$ introduced into solution is greater in the $\mathrm{HNO}_{3} /[\mathrm{BMIM}]\left[\mathrm{Tf}_{2} \mathrm{~N}\right]$ experiment, because, a solution of $70 \%$ wt $/$ wt $\mathrm{HNO}_{3}$ was used as a nitrate source. Kaplan et al. ${ }^{22}$ studied the formation of the $\mathrm{UO}_{2}\left(\mathrm{NO}_{3}\right)_{3}{ }^{-}$complex in organic solvents using UV-visible spectrophotometry. The authors noted that the equilibrium reaction

$$
\mathrm{UO}_{2}\left(\mathrm{NO}_{3}\right)_{2}+\mathrm{NO}_{3}{ }^{-} \rightleftharpoons \mathrm{UO}_{2}\left(\mathrm{NO}_{3}\right)_{3}{ }^{-}
$$

is affected by the presence of water and suggested that a nitrate ion and water molecules compete for a coordination position around the uranyl(VI) ion. Billard et al. ${ }^{23}$ also noted that the formation of the $\mathrm{UO}_{2}\left(\mathrm{NO}_{3}\right)_{3}{ }^{-}$complex in [BMIM] $\left[\mathrm{Tf}_{2} \mathrm{~N}\right]$ is affected by the presence of water. In our study, no significant shifts in $v_{\text {as }}\left(\mathrm{UO}_{2}\right)$ were seen in solutions of $0.1 \mathrm{M}$ $\mathrm{UO}_{2}\left(\mathrm{NO}_{3}\right)_{2} \cdot 6 \mathrm{H}_{2} \mathrm{O}$ or $0.1 \mathrm{M} \mathrm{UO}_{2}\left(\mathrm{Tf}_{2} \mathrm{~N}\right)_{2}$ in [BMIM] $\left[\mathrm{Tf}_{2} \mathrm{~N}\right]$ to which aliquots of water were deliberately added. Thus, water is not a strong enough ligand in $[\mathrm{BMIM}]\left[\mathrm{Tf}_{2} \mathrm{~N}\right]$ to displace $\mathrm{NO}_{3}{ }^{-}$or otherwise affect the $\mathrm{O}=\mathrm{U}=\mathrm{O}$ bond strength.

\section{Conclusions}

We have conducted a detailed spectroscopic examination of the uranyl(VI) nitrate system in [BMIM] $\left[\mathrm{Tf}_{2} \mathrm{~N}\right]$, using ATR-FTIR spectrometry to characterize the coordination environment of uranyl(VI) in solutions of [BMIM] $\left[\mathrm{Tf}_{2} \mathrm{~N}\right]$ containing either TBAN or $\mathrm{HNO}_{3}$. Both $\mathrm{UO}_{2}\left(\mathrm{NO}_{3}\right)_{2}$ and $\mathrm{UO}_{2}\left(\mathrm{NO}_{3}\right)_{3}{ }^{-}$species were detected. $v_{\text {as }}\left(\mathrm{UO}_{2}\right)$ for these two species were found to appear at 951 and $944 \mathrm{~cm}^{-1}$, respectively, while $v_{\text {as }}\left(\mathrm{UO}_{2}\right)$ arising from uranyl(VI) coordinated by $\mathrm{Tf}_{2} \mathrm{~N}^{-}$anions in [BMIM] $\left[\mathrm{Tf}_{2} \mathrm{~N}\right]$ appears at $968 \mathrm{~cm}^{-1}$. The $\mathrm{UO}_{2}\left(\mathrm{NO}_{3}\right)^{+}$species was not detected under the conditions used in this study. Formation of the uranyl(VI) nitrate complexes may also be followed through the growth of the $v(\mathrm{NO})$ mode at $1537 \mathrm{~cm}^{-1}$, which is diagnostic for nitrate that 
is coordinated to a metal ion. The $\mathrm{UO}_{2}\left(\mathrm{NO}_{3}\right)_{3}{ }^{-}$complex did not form in solutions of [BMIM] $\left[\mathrm{Tf}_{2} \mathrm{~N}\right.$ ] containing $\mathrm{HNO}_{3}$ under our experimental conditions, likely as a result of competition from water. More research is needed to examine the role that water and other potentially competing species play in uranyl(VI) solution chemistry in RTIL. Overall, our results indicate that infrared spectroscopy can form a valuable addition to the suite of tools currently used to study the chemical behavior of uranyl(VI) in RTIL.
Acknowledgment. S.P.P. gratefully acknowledges startup funding from the University of Idaho College of Science. C.M.W. and D.L.Q. acknowledge the DOE Nuclear Energy University Programs (NE-UP Grant No. TO 00058) for financial support.

Supporting Information Available: UV-visible and infrared spectra. This material is available free of charge via the Internet at http://pubs.acs.org. 


\title{
Dalton Transactions
}

View Article Online / Journal Homepage / Table of Contents for this issue

Dynamic Article Links

Cite this: Dalton Trans., 2011, 40, 5039

WWw.rsc.org/dalton

PAPER

\section{Uranium dioxide in ionic liquid with a tri-n-butylphosphate- $\mathrm{HNO}_{3}$ complex-dissolution and coordination environment ${ }^{\dagger}$}

\author{
Sofie P. Pasilis ${ }^{a}$ \\ Received 2nd November 2010, Accepted 28th February 2011 \\ DOI: 10.1039/c0dt01518k

\begin{abstract}
Uranium dioxide can be dissolved directly in an imidazolium-based ionic liquid (IL) at room temperature with a tri-n-butylphosphate(TBP)- $\mathrm{HNO}_{3}$ complex. The dissolution process follows pseudo first-order kinetics initially. Raman spectroscopic studies show the dissolved uranyl ions are coordinated with TBP in the IL phase with a molar ratio of $\left(\mathrm{UO}_{2}\right)^{2+}: \mathrm{TBP}=1: 2$. The dissolved uranyl species can be effectively transferred to a supercritical fluid carbon dioxide $\left(\mathrm{sc}-\mathrm{CO}_{2}\right)$ phase. No aqueous phase is formed in either the IL dissolution or the supercritical fluid extraction process. Absorption spectra of the extracted uranyl species in the sc- $\mathrm{CO}_{2}$ phase suggests the presence of a $\mathrm{UO}_{2}(\mathrm{TBP})_{2}\left(\mathrm{NO}_{3}\right)_{2}$ and $\mathrm{HNO}_{3}$ adduct probably of the form $\mathrm{UO}_{2}(\mathrm{TBP})_{2}\left(\mathrm{NO}_{3}\right)_{2} \cdot \mathrm{HNO}_{3}$. The adduct dissociates in a water-dodecane trap solution during pressure reduction resulting in $\mathrm{UO}_{2}(\mathrm{TBP})_{2}\left(\mathrm{NO}_{3}\right)_{2}$ collected in the dodecane phase.
\end{abstract}

Chien M. Wai, ${ }^{* a}$ Yu-Jung Liao, ${ }^{a}$ Weisheng Liao, ${ }^{a}$ Guoxin Tian, ${ }^{b}$ Raymond S. Addleman, ${ }^{c}$ Donna Quach ${ }^{a}$ and

\section{Introduction}

Using room-temperature ionic liquids (RTILs) as alternatives to conventional solvents for treating nuclear wastes has become an active research area in recent years. ${ }^{1-25}$ Ionic liquids have unique properties including near zero vapour pressure, nonflammability, thermal and radiation stability, and good solubility for a variety of chemical species including ions and neutral compounds. ${ }^{26}$ One type of RTIL, which consists of a 1-butyl3-methylimidazolium (BMIM) cation and a fluorinated anion such as bis(trifluoromethane)sulfonimide $\left(\mathrm{Tf}_{2} \mathrm{~N}\right)$, has been studied for extraction of metal ions due to its hydrophobicity and aqueous stability. However, separation of dissolved metal species from RTILs by conventional methods, such as acid stripping, distillation, or organic solvent back-extraction, is often inefficient and may cause cross-contamination due to their mutual solubility. It is known that supercritical carbon dioxide (sc- $\mathrm{CO}_{2}$ ) can dissolve in RTILs effectively, whereas the latter have negligible solubility in sc- $\mathrm{CO}_{2}{ }^{27}$ This property allows effective recovery of dissolved metal species in RTIL by sc- $\mathrm{CO}_{2}$ extraction without contamination or loss of the RTIL.

Several researchers have used room-temperature ionic liquids (RTILs) as solvents for dissolution or extraction of actinides. ${ }^{1-25,28}$

'Department of Chemistry, University of Idaho, Moscow, Idaho, 83844 USA. E-mail: cwai@uidaho.edu; Fax: +1 208-885-6173; Tel: +1 208-8856787

${ }^{b}$ Glenn T. Seaborg Center, Lawrence Berkeley National Lab, Berkeley, California, 94720 , USA

'Pacific Northwest National Lab, Richland, Washington, 99352, USA

$\dagger$ Electronic supplementary information (ESI) available. See DOI: $10.1039 / \mathrm{codt} 01518 \mathrm{k}$
Allen et al. has noted a series of ILs for the radiochemical stability. ${ }^{19}$ Visser et al. reported that some actinide ions could be extracted from $1 \mathrm{M} \mathrm{HNO}_{3}$ solution into different ILs or dodecane by a mixture of $0.1 \mathrm{M}$ octyl(phenyl)- $N, N$-diisobutylcarbamoylmethyl phosphine oxide (CMPO) and $1 \mathrm{M}$ tri-n-butylphosphate (TBP) and the results showed an enhancement of distribution ratios in the ILs over dodecane. ${ }^{11,12,14}$ These literature reports also noted that the EXAFS measurement showed the extracted complex of $\mathrm{UO}_{2}{ }^{2+}$ in IL systems was $\mathrm{UO}_{2}\left(\mathrm{NO}_{3}\right)(\mathrm{CMPO})^{+}$, but the extracted complex in dodecane was neutral $\mathrm{UO}_{2}\left(\mathrm{NO}_{3}\right)_{2}(\mathrm{CMPO})_{2} .11,12,14$ However, extraction of $\mathrm{UO}_{2}{ }^{2+}$ from $0.25 \mathrm{M} \mathrm{HNO}_{3}$ with bis(2ethylhexyl)phosphoric acid (HDEHP) into the IL [ $\left.\mathrm{C}_{8} \operatorname{mim}\right]\left[\mathrm{Tf}_{2} \mathrm{~N}\right]$ was reported to be a neutral complex which was identical to that extracted into dodecane as elucidated by EXAFS and UV-Vis spectroscopy measurements. ${ }^{13}$ The extraction of uranium(VI) from nitric acid by TBP dissolved in the ionic liquid $[\mathrm{Bmim}]\left[\mathrm{PF}_{6}\right]$ has also been reported..$^{916-18}$ Giridhar et al. ${ }^{17}$ showed that based on the slope analysis of the distribution coefficients the apparent stoichiometry of uranyl species extracted by TBP from nitric acid solutions into $[\mathrm{BMIM}]\left[\mathrm{PF}_{6}\right]$ was $\mathrm{UO}_{2}\left(\mathrm{NO}_{3}\right)_{2} \cdot 2 \mathrm{TBP}$ when the concentration of nitric acid was less than $4 \mathrm{M}$.

A recent report shows that uranyl ions $\left(\mathrm{UO}_{2}\right)^{2+}$ in $3 \mathrm{M}$ nitric acid can be extracted into [BMIM] $\left.\mathrm{Tf}_{2} \mathrm{~N}\right]$ at room temperature containing tri-n-butylphosphate (TBP) and then back-extracted into a sc- $\mathrm{CO}_{2}$ phase. $^{3}$ The nature of the uranyl species dissolved in the IL is not well understood. In this three-phase (aqueous/IL/sc$\mathrm{CO}_{2}$ ) extraction process, the IL serves as a recyclable medium for extraction and concentration of uranium from the acid solution under ambient pressure and temperature. The three-phase extraction process is suitable for treating uranium contaminated aqueous solutions. Direct dissolution of $\mathrm{UO}_{2}$ in ionic liquids 
using concentrated nitric acid has been reported by several researchers. ${ }^{1,28}$ The uranyl species dissolved in [BMIM] $\left[\mathrm{Tf}_{2} \mathrm{~N}\right]$ with nitric acid are not extractable by sc- $\mathrm{CO}_{2}$. The solubility of water (about $1.2 \%$ by weight) in the IL also limits the amount of uranium dioxide which can be dissolved in the IL phase without forming an aqueous phase.

This paper reports a method of dissolving uranium dioxide directly in [BMIM] $\left[\mathrm{Tf}_{2} \mathrm{~N}\right]$ at room temperature using a $\mathrm{TBP}\left(\mathrm{HNO}_{3}\right)_{1.8}\left(\mathrm{H}_{2} \mathrm{O}\right)_{0.6}$ complex which is miscible with the IL without formation of an aqueous phase. In this study, we use Raman spectroscopy to evaluate the coordination environment of uranium species dissolved in the IL with the TBP- $\mathrm{HNO}_{3}$ complex. It is known that the symmetrical vibrational mode of uranyl ions $(\mathrm{O}=\mathrm{U}=\mathrm{O})^{2+}$ is Raman active and this band does not overlap with the Raman bands of [BMIM][Tf $\left.{ }_{2} \mathrm{~N}\right]$ according to our experiments. Thus, Raman spectroscopy provides a good tool for studying the coordination environment of uranyl ions dissolved in the IL system. Using vibrational spectroscopy (FTIR) to characterize uranyl nitrate complexes in ionic liquid was reported recently by our group. ${ }^{29}$ To the best of our knowledge, this paper represents the first systematic investigation of the coordination environment of an actinide in ionic liquid and in supercritical $\mathrm{CO}_{2}$ using Raman spectroscopy. An interesting observation from our Raman study is that the dissolved uranyl species is coordinated with two molecules of TBP and probably exists as a mixture of the form $\mathrm{UO}_{2}(\mathrm{TBP})_{2}\left(\mathrm{NO}_{3}\right)_{x}$ in the IL system where $x$ may be 1 , 2 , or 3. The rate of dissolution of $\mathrm{UO}_{2}$ in the IL and transfer of the dissolved uranyl species to $\mathrm{sc}-\mathrm{CO}_{2}$ are also described. After supercritical fluid extraction, the IL can be reused for $\mathrm{UO}_{2}$ dissolution. This $\mathrm{IL} / \mathrm{sc}-\mathrm{CO}_{2}$ hyphenated process, which enables continuous dissolution of uranium in the IL with subsequent transfer to $\mathrm{sc}-\mathrm{CO}_{2}$ without formation of an aqueous phase, may provide a new green technique for recycling uranium from solid wastes.

\section{Experimental}

\section{Chemicals and sample preparation}

Uranium dioxide $\left(\mathrm{UO}_{2} 200-325\right.$ mesh size) was purchased from Internal Bio-Analytical Industries, Inc. (Boca Raton, FL). Concentrated nitric acid $(70 \% \mathrm{w} / \mathrm{w})$, tri-nbutylphosphate (TBP), tri-n-butylphosphine oxide (TBPO), 1-butyl-3-methylimidazolium chloride, $[\mathrm{BMIM}] \mathrm{Cl}$, and bis(trifluoromethane)sulfonimide lithium salt, $\left[\mathrm{LiN}\left(\mathrm{CF}_{3} \mathrm{SO}_{2}\right)_{2}\right]$ were purchased from Aldrich (Milwaukee, WI). Carbon dioxide $(99.99 \%)$ was supplied by Oxarc (Spokane, WA). [BMIM][Tf 2 N] was prepared by metathesis of [BMIM]Cl with aqueous $\mathrm{LiN}\left(\mathrm{CF}_{3} \mathrm{SO}_{2}\right)_{2}$ and dried under vacuum at $65^{\circ} \mathrm{C}$ for $24 \mathrm{~h} .{ }^{3}$ The amount of water in [BMIM] $\left[\mathrm{Tf}_{2} \mathrm{~N}\right]$ measured by Karl Fischer titration was $405 \mathrm{ppm}$. Neutron activation analysis showed the chloride content in the IL was about $4 \mathrm{ppm}$. A $\mathrm{CO}_{2}$-soluble TBP- $\mathrm{HNO}_{3}$ complex of the form TBP $\left(\mathrm{HNO}_{3}\right)_{1.8}\left(\mathrm{H}_{2} \mathrm{O}\right)_{0.6}$ was prepared by shaking an equal volume mixture of TBP and the concentrated nitric acid in a capped vial. Characterization of the TBP- $\mathrm{HNO}_{3}$ complex is given in the literature. ${ }^{30}$ After mixing and phase separation, the organic phase containing the $\mathrm{TBP}\left(\mathrm{HNO}_{3}\right)_{1.8}\left(\mathrm{H}_{2} \mathrm{O}\right)_{0.6}$ complex was removed from the mixture for the uranium dissolution experiments.

\section{Experimental setup}

The experimental setup for the high pressure system was the same as described in a previous publication. ${ }^{3}$ An ISCO syringe pump (Model 206D, Lincoln, NB) with a series D pump controller was used to pressurize the system with $\mathrm{CO}_{2}$. The parts of the high-pressure extraction system including view-cell, extraction cell, valves, and connectors were either home-made or purchased from High Pressure Equipment Company (HiP, Erie, PA). A high-pressure fiber-optic cell connected to a UV/Vis spectrometer with CCD array (Model 440, Spectral Instruments, Inc., Tucson, AZ) was used for in situ spectroscopic measurement of the $\mathrm{CO}_{2}$ phase. Pressure and temperature inside the fiber-optic cell were monitored by a pressure gauge (Omega Engineering, Inc.) and a thermocouple (Model HH23, KMTSS-062U-6, Omega), respectively.

Dissolution of $\mathrm{UO}_{2}$ in [BMIM][Tf $\left.{ }_{2} \mathrm{~N}\right]$ was performed at room temperature and ambient pressure using an $8 \mathrm{~mL}$ glass vial placed on a magnet stirrer. The stirring speed of the IL phase was measured by a Neiko tachometer (Model 20713, Neiko Tools, Amazon). A Renishaw Ramascope Raman microscope having a $785 \mathrm{~nm}$ laser (Renishaw, UK) was used to obtain Raman spectra of uranyl species dissolved in the IL phase. Raman spectra were acquired on samples contained in sealed NMR tubes. In addition, a portable Raman spectrometer (Enwave Optronics, Inc., Irvine, CA.) was used to collect Raman spectra of uranyl species dissolved in the sc- $-\mathrm{CO}_{2}$ phase through quartz windows of a high-pressure stainless steel view-cell.

\section{Experimental procedure}

The experimental procedure for direct dissolution of $\mathrm{UO}_{2}$ in [BMIM] $\left[\mathrm{Tf}_{2} \mathrm{~N}\right]$ containing TBP $\left(\mathrm{HNO}_{3}\right)_{1.8}\left(\mathrm{H}_{2} \mathrm{O}\right)_{0.6}(16.7 \% \mathrm{v} / \mathrm{v})$ is described as follows: (1) $600 \mu \mathrm{L}$ of TBP- $\mathrm{HNO}_{3}$ was added to $3 \mathrm{~mL}$ of [BMIM][Tf $\left.\mathrm{T}_{2} \mathrm{~N}\right]$ in an $8 \mathrm{~mL}$ glass vial and subjected to continuous stirring at room temperature and (2) an initial amount of $26.2 \mathrm{mg}$ of $\mathrm{UO}_{2}$ was added to the solution and the rate of dissolution monitored by UV/Vis spectroscopy. Because the TBP$\mathrm{HNO}_{3}$ complex carries a small amount of water into the system, the water content during dissolution of $\mathrm{UO}_{2}$ was estimated to be around $4300 \mathrm{ppm}$, well below the saturation point of water in the IL. To evaluate the maximum amount of $\mathrm{UO}_{2}$ dissolution in the $\mathrm{IL}$, separate aliquots of $\mathrm{UO}_{2}$ were added to the [BMIM] $\left[\mathrm{Tf}_{2} \mathrm{~N}\right.$ ] phase after the initial addition and the UV/Vis spectra of the $[\mathrm{BMIM}]\left[\mathrm{Tf}_{2} \mathrm{~N}\right]$ phase were recorded two hours after each addition of $\mathrm{UO}_{2}$.

For Raman measurements of uranyl nitrate-TBP complexes in the IL, [BMIM] $\left[\mathrm{Tf}_{2} \mathrm{~N}\right]$, samples with different molar ratios of $\mathrm{UO}_{2}\left(\mathrm{NO}_{3}\right)_{2} \cdot 6 \mathrm{H}_{2} \mathrm{O}: \mathrm{TBP}(1: 0,1: 0.25,1: 0.5,1: 1,1: 2$, and $1: 3)$ were prepared. Another sample was prepared with $\mathrm{UO}_{2}\left(\mathrm{NO}_{3}\right)_{2} \cdot 6 \mathrm{H}_{2} \mathrm{O}$ and tributylphosphine oxide (TBPO) at a molar ratio of $1: 2$ in [BMIM] $\left[\mathrm{Tf}_{2} \mathrm{~N}\right.$ ] for comparison. After thoroughly mixing, a small amount of the IL sample was taken and placed in a sealed NMR tube for Raman measurement. Raman spectra of uranyl species in $\mathrm{sc}-\mathrm{CO}_{2}$ were measured using a home-made view cell with uranyl species extracted from [BMIM] $\left[\mathrm{Tf}_{2} \mathrm{~N}\right]$ following the supercritical fluid extraction procedure described in a previous report. $^{3}$ 


\section{Results and discussion}

Dissolution of uranium dioxide in $\mathrm{IL}$ with $\mathrm{TBP}\left(\mathrm{HNO}_{3}\right)_{1.8}\left(\mathrm{H}_{2} \mathrm{O}\right)_{0.6}$

The $\mathrm{TBP}\left(\mathrm{HNO}_{3}\right)_{1.8}\left(\mathrm{H}_{2} \mathrm{O}\right)_{0.6}$ complex is miscible with [BMIM][Tf $2 \mathrm{~N}]$, forming one homogeneous liquid phase at the volume ratio $(1: 5)$ described in the experimental section. With $26.2 \mathrm{mg}$ of solid $\mathrm{UO}_{2}$ added to $3.6 \mathrm{~mL}$ of the [BMIM] $\left[\mathrm{Tf}_{2} \mathrm{~N}\right.$ ] solution, the ratios of $[\mathrm{TBP}] /[\mathrm{U}]$, $\left[\mathrm{HNO}_{3}\right] /[\mathrm{U}]$, and $\left[\mathrm{H}_{2} \mathrm{O}\right] /[\mathrm{U}]$ in the IL phase were about 16,28 , and 11 , respectively. With stirring, the black $\mathrm{UO}_{2}$ powder gradually dissolved in the $[\mathrm{BMIM}]\left[\mathrm{Tf}_{2} \mathrm{~N}\right]$ solution, turning the colour of the IL phase to bright yellow. The dissolution process was monitored by acquiring UV/Vis spectra of the IL phase at different times as shown in Fig. la. About $81 \%$ of the $\mathrm{UO}_{2}(\mathrm{~s})$ dissolved in the IL phase at room temperature in the first hour and $8 \%$ more dissolved in the second hour. Absorbances of the peaks at $372,388,437$, and $452 \mathrm{~nm}$ with respect to dissolution time are shown in Fig. 1b. The intensities of the peaks at 437 , and $452 \mathrm{~nm}$ increased rapidly with time in the first $60 \mathrm{~min}$ and reached a plateau in about $120 \mathrm{~min}$. However, the peaks at 372 and $388 \mathrm{~nm}$ reached a maximum absorption at $66 \mathrm{~min}$ and then decreased after that. This observation was similar to a previous report in which the dissolution of $\mathrm{UO}_{2}$ in $[\mathrm{BMIM}]\left[\mathrm{Tf}_{2} \mathrm{~N}\right]$ containing aqueous nitric acid was studied at room temperature by $\mathrm{UV} / \mathrm{Vis}$ spectroscopy at a $\left[\mathrm{HNO}_{3}\right] /[\mathrm{U}]$ ratio of 16 and $\left[\mathrm{H}_{2} \mathrm{O}\right] /[\mathrm{U}]$ ratio of $33 .{ }^{1}$ The absorption peaks at wavelengths above $400 \mathrm{~nm}$ were reported to increase from 0 to $66 \mathrm{~min}$ and then remain practically constant for up to $900 \mathrm{~min}$.
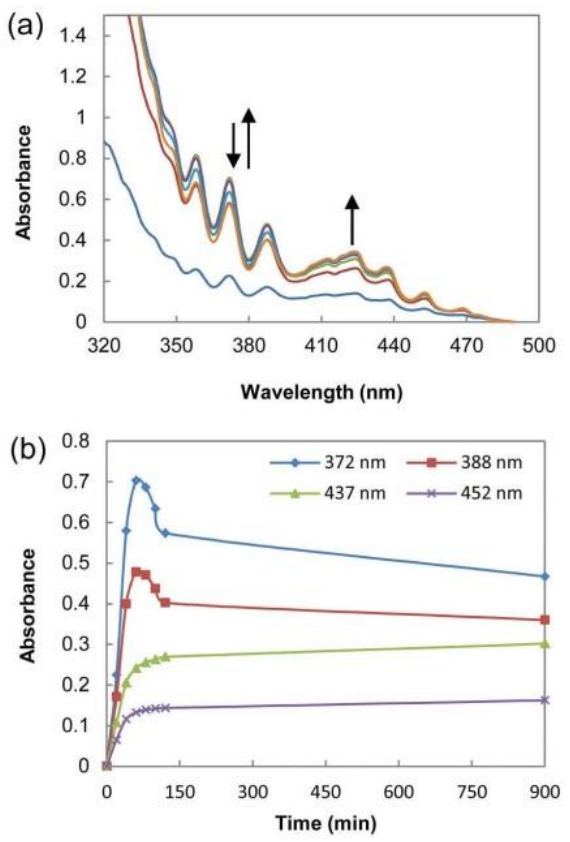

Fig. 1 Rate of dissolution of $\mathrm{UO}_{2}(\mathrm{~s})$ in $[\mathrm{BMIM}]\left[\mathrm{Tf}_{2} \mathrm{~N}\right]$ with $\mathrm{TBP}\left(\mathrm{HNO}_{3}\right)_{1.8}\left(\mathrm{H}_{2} \mathrm{O}\right)_{0.6}(16.7 \%$ by volume $)$ at room temperature: (a) $\mathrm{UV} / \mathrm{Vis}$ spectra between 320 and $500 \mathrm{~nm}$; (b) absorbance versus dissolution time ( $\mathrm{min}$ ) for peaks at $372,388,437$, and $452 \mathrm{~nm}$.
But, the peaks at wavelengths below $400 \mathrm{~nm}$ were found to increase in the first $66 \mathrm{~min}$, followed by a decrease in absorbance after that. The cause of the fluctuations in absorption for the peaks below $400 \mathrm{~nm}$ was attributed to the formation of transient absorbing species during the dissolution process which involves oxidation of $\mathrm{U}(\mathrm{IV})$ to $\mathrm{U}(\mathrm{VI})$ via $\mathrm{NO}_{3}^{-} / \mathrm{NO}_{2}^{-}$reduction and changes in background absorption. ${ }^{1}$

The rate of dissolution of $\mathrm{UO}_{2}$ in $[\mathrm{BMIM}]\left[\mathrm{Tf}_{2} \mathrm{~N}\right]$ with $\mathrm{TBP}\left(\mathrm{HNO}_{3}\right)_{1.8}\left(\mathrm{H}_{2} \mathrm{O}\right)_{0.6}$ at room temperature $\left(23^{\circ} \mathrm{C}\right)$ depends on the stirring speed of the magnetic stirrer. Between 900 and 1200 rpm, the dissolution rate of $\mathrm{UO}_{2}$ in this $\mathrm{IL}$ system reaches near a constant under our experimental conditions. Therefore, all $\mathrm{UO}_{2}$ dissolution experiments in this study were carried out at a stirring speed of $1200 \pm 10 \mathrm{rpm}$. The stirring speed was checked by tachometer measurements. Stirring is always required in conventional nitric acid dissolution of $\mathrm{UO}_{2}$ powder ${ }^{31}$ but the speed is usually much lower compared with our IL dissolution process due to the high viscosity of IL.

The initial rate of dissolution of $\mathrm{UO}_{2}$ in the IL (Fig. 1b) increases exponentially and resembles first order kinetics. A plot of $\ln \left[\left(A_{e}\right.\right.$ $-A) / A_{\text {s.] }}$ versus time is shown in Fig. 2, where $A$ is the absorbance at time $t$ and $A_{\infty}$ is taken as the absorbance at $900 \mathrm{~min}$. The absorption data at $437 \mathrm{~nm}$ and at $452 \mathrm{~nm}$ are used in this plot and both absorption peaks give the same result. The initial dissolution appears to follow a pseudo first-order kinetics as demonstrated by the linear relationship between $\ln \left[\left(A_{\infty}-A\right) / A_{\infty}\right]$ and $t$ shown in Fig. 2. The slope of the line is $0.028 \mathrm{~min}^{-1}$ (or $t_{\downarrow}=24.7 \mathrm{~min}$ ), which may be regarded as the rate constant of the initial pseudo first-order dissolution process for $\mathrm{UO}_{2}$ in $[\mathrm{BMIM}]\left[\mathrm{Tf}_{2} \mathrm{~N}\right]$ with $\mathrm{TBP}\left(\mathrm{HNO}_{3}\right)_{1.8}\left(\mathrm{H}_{2} \mathrm{O}\right)_{0.6}$.

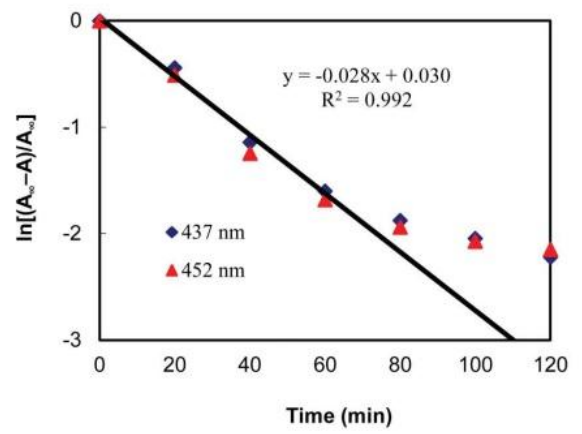

Fig. 2 Plot of $\ln \left[\left(A_{\infty}-A\right) / A_{\ldots}\right]$ versus time for the dissolution of $\mathrm{UO}_{2}$ in [BMIM] $\left[\mathrm{Tf}_{2} \mathrm{~N}\right.$ ] containing $\mathrm{TBP}\left(\mathrm{HNO}_{3}\right)_{1.8}\left(\mathrm{H}_{2} \mathrm{O}\right)_{0.6}$.

The dissolution process can be envisioned to involve a number of steps including diffusion of $\mathrm{TBP}\left(\mathrm{HNO}_{3}\right)_{1.8}\left(\mathrm{H}_{2} \mathrm{O}\right)_{0.6}$ to the $\mathrm{UO}_{2}$ surface, oxidation of $\mathrm{UO}_{2}$ to uranyl on the $\mathrm{UO}_{2}$ surface, and diffusion of uranyl species from the solid surface to the IL phase. Diffusion of the uranyl species from the $\mathrm{UO}_{2}$ surface to the IL phase is probably a main factor controlling the rate of dissolution of $\mathrm{UO}_{2}$. Deviation from the linear relationship occurs after $60 \mathrm{~min}$ indicating occurrence of other processes which would affect the steady diffusion of uranyl at higher uranium concentrations in the IL phase. 
To evaluate the maximum amount of $\mathrm{UO}_{2}$ dissolution in the [BMIM] $\left[\mathrm{Tf}_{2} \mathrm{~N}\right] / \mathrm{TBP}\left(\mathrm{HNO}_{3}\right)_{1.8}\left(\mathrm{H}_{2} \mathrm{O}\right)_{0.6}$ system, different amounts of $\mathrm{UO}_{2}$ were added to the IL phase repeatedly every two hours. After each addition, the IL phase was stirred for two hours and then analysed by UV/Vis spectroscopy (Fig. 3a). The absorption peaks at 437,452 , and $468 \mathrm{~nm}$ increase linearly with increasing amounts of dissolved $\mathrm{UO}_{2}$. After addition of $234.9 \mathrm{mg}(0.24 \mathrm{M})$ of $\mathrm{UO}_{2}$, the absorbances of peaks at wavelengths below $437 \mathrm{~nm}$ begin to fluctuate. Fig. $3 \mathrm{~b}$ shows the absorbance for peaks at 437,452 , and $468 \mathrm{~nm}$ with respect to increasing amount of $\mathrm{UO}_{2}$ dissolved in the IL phase. Generally speaking, the absorbance increases close to a linear fashion with the amount of $\mathrm{UO}_{2}$ added to the system up to $245 \mathrm{mg}$. After addition of over $320 \mathrm{mg}$ of $\mathrm{UO}_{2}(0.33 \mathrm{M})$, black slurry started to appear in the IL phase, suggesting that the system had reached its saturation point under the experimental conditions. This quantity $\left.(320 \mathrm{mg} \mathrm{UO})_{2}\right)$ is considered as the maximum amount of $\mathrm{UO}_{2}$ soluble in $3.6 \mathrm{~mL}$ of [BMIM][Tf $\left.f_{2} \mathrm{~N}\right]$ at room temperature $\left(23{ }^{\circ} \mathrm{C}\right)$.
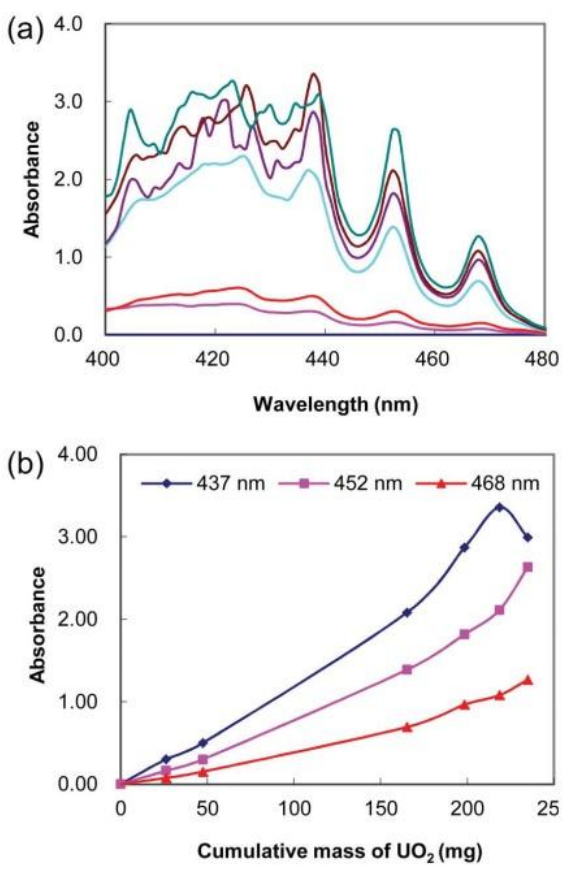

Fig. 3 Cumulative $\mathrm{UO}_{2}$ dissolution in $[\mathrm{BMIM}]\left[\mathrm{Tf}_{2} \mathrm{~N}\right]$ with $\mathrm{TBP}\left(\mathrm{HNO}_{3}\right)_{1.8}\left(\mathrm{H}_{2} \mathrm{O}\right)_{0.6}$ at room temperature: (a) UV/Vis spectra between 400 and $480 \mathrm{~nm}$; (b) absorbance versus cumulative mass of $\mathrm{UO}_{2}$ plot at 437,453 , and $468 \mathrm{~nm}$.

\section{Raman spectra of uranyl species in IL}

One interesting property of ILs is their unusual solvation character, which is reflected in their ability to dissolve many chemical materials including both ionic species and neutral compounds. ${ }^{1,26}$ Understanding the chemical environment of uranyl and other actinide species dissolved in an IL system is important for applying the technology to managing uranium-containing wastes. The absorption spectra of uranyl nitrate dissolved in [BMIM] $\left[\mathrm{Tf}_{2} \mathrm{~N}\right]$ have been described in the literature. ${ }^{1,32,33}$ Comparing our UV/Vis spectrum with those reported in the literature, ${ }^{1}$ the absorption spectra of uranyl species with and without TBP show a difference in the wavelength range between $390-430 \mathrm{~nm}$. We cannot determine whether the dissolved uranyl ions exist in the IL phase as individual ions or are associated with TBP. It is known that the Raman active uranyl symmetrical stretching mode, $v_{\mathrm{s}}\left(\mathrm{UO}_{2}\right)$, is sensitive to changes in uranyl coordination environment; complexation of the uranyl( $(\mathrm{vI})$ ion weakens the $\mathrm{O}=\mathrm{U}=\mathrm{O}$ bonds, causing $v_{\mathrm{s}}\left(\mathrm{UO}_{2}\right)$ to shift to lower frequency. Thus, Raman spectroscopy may provide information regarding the coordination environment of the uranyl ions dissolved in the IL system. Fig. 4 shows typical Raman spectra of [BMIM] $\left[\mathrm{Tf}_{2} \mathrm{~N}\right]$ with and without dissolved uranyl species. The vibrational bands at $825,908,884,1025$, and $1056 \mathrm{~cm}^{-1}$ visible in all four spectra arise from [BMIM] $\left[\mathrm{Tf}_{2} \mathrm{~N}\right]$. The mode at $1025 \mathrm{~cm}^{-1}$ has been assigned to the in-plane symmetric stretching mode of the imidazolium ring. ${ }^{34} \mathrm{If}$ only $\mathrm{UO}_{2}\left(\mathrm{NO}_{3}\right)_{2} \cdot 6 \mathrm{H}_{2} \mathrm{O}$ is dissolved in the IL (spectrum $4 \mathrm{~b}$ ), the symmetrical stretching mode, $v_{\mathrm{s}}\left(\mathrm{UO}_{2}\right)$, occurs at $868 \mathrm{~cm}^{-1}$, indicating the $\mathrm{O}=\mathrm{U}=\mathrm{O}$ bond strength is roughly the same as it is in aqueous solution at low $\mathrm{pH}$ values, where a band at $870 \mathrm{~cm}^{-1}$ arises from the solvated $\mathrm{UO}_{2}\left(\mathrm{H}_{2} \mathrm{O}\right)_{5}{ }^{2+}$ cation. ${ }^{35}$ From the spectroscopic data, it is reasonable to postulate that the uranyl cation is solvated in [BMIM] $\left[\mathrm{Tf}_{2} \mathrm{~N}\right]$, but that the $\mathrm{O}=\mathrm{U}=\mathrm{O}$ bond is not perturbed. When TBP is added to the IL phase containing dissolved $\mathrm{UO}_{2}{ }^{2+}$, the $v_{s}\left(\mathrm{UO}_{2}\right)$ band shifts to lower wavenumber, reaching a well-defined peak at $860 \mathrm{~cm}^{-1}$ when the molar ratio of TBP to uranyl reaches a value of 2 (spectrum $4 \mathrm{c}$ ). The shift to lower wavenumber upon addition of TBP to the IL solution indicates that the coordination environment of $\mathrm{UO}_{2}{ }^{2+}$ has changed and TBP is associated with the uranyl ion. To test the $\mathrm{P}=\mathrm{O}$ coordination with uranyl in the IL, TBPO (tri-n-butylphosphine oxide) was added to the IL/ $/ \mathrm{UO}_{2}\left(\mathrm{NO}_{3}\right)_{2} \cdot 6 \mathrm{H}_{2} \mathrm{O}$ solution, resulting in a shift of $v_{\mathrm{s}}\left(\mathrm{UO}_{2}\right)$ to $845 \mathrm{~cm}^{-1}$ (spectrum 4d). The appearance of $v_{\mathrm{s}}\left(\mathrm{UO}_{2}\right)$

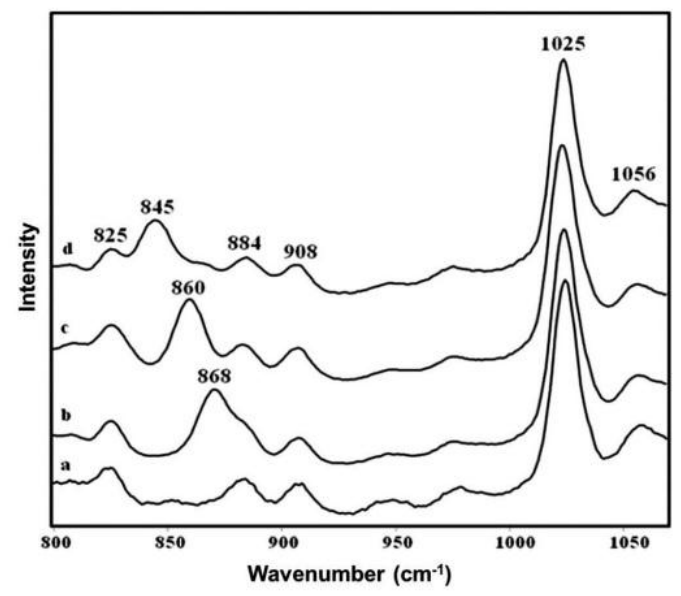

Fig. 4 Raman spectra of (a) [BMIM][Tf $\left.f_{2} \mathrm{~N}\right]$ only, (b) $0.17 \mathrm{M}$ $\mathrm{UO}_{2}\left(\mathrm{NO}_{3}\right)_{2} \cdot 6 \mathrm{H}_{2} \mathrm{O}$ in [BMIM][Tf $2 \mathrm{~N}$ ], (c) $0.17 \mathrm{M} \mathrm{UO}_{2}\left(\mathrm{NO}_{3}\right)_{2} \cdot 6 \mathrm{H}_{2} \mathrm{O}$ and $0.34 \mathrm{M}$ TBP in [BMIM][Tf $\left.{ }_{2} \mathrm{~N}\right]$, and (d) $0.17 \mathrm{M} \mathrm{UO}_{2}\left(\mathrm{NO}_{3}\right)_{2} \cdot 6 \mathrm{H}_{2} \mathrm{O}$ and 0.34 $\mathrm{M}$ TBPO in [BMIM] $\left[\mathrm{Tf}_{2} \mathrm{~N}\right]$. 
at a lower frequency for the uranyl-TBPO complex relative to $v_{\mathrm{s}}\left(\mathrm{UO}_{2}\right)$ for the uranyl-TBP complex is expected, as TBPO is a stronger Lewis base than TBP.

Fig. 5 shows Raman spectra of the IL solutions having varying molar ratios of $\mathrm{UO}_{2}: \mathrm{TBP}$. The $v_{\mathrm{s}}\left(\mathrm{UO}_{2}\right)$ mode at $860 \mathrm{~cm}^{-1}$ does not change when the molar ratio of $\mathrm{TBP} / \mathrm{UO}_{2}$ exceeds 2 (Fig. 5). The Raman data suggest that probably two molecules of TBP are coordinated with each uranyl ion in [BMIM] $\left[\mathrm{Tf}_{2} \mathrm{~N}\right]$. In our Raman study we do not see the $v_{s}\left(\mathrm{NO}_{3}\right)^{-}$mode, which normally appears at $1047 \mathrm{~cm}^{-1}$ in aqueous solutions of uranyl nitrate. ${ }^{36}$ Our spectra also do not show vibrational modes resulting from nitrate bound to uranyl ion $\left(752 \mathrm{~cm}^{-1}, 1036 \mathrm{~cm}^{-1}, 1304 \mathrm{~cm}^{-1}\right.$ in aqueous solutions) ${ }^{36}$ These peaks are likely buried under the $[\mathrm{BMIM}]\left[\mathrm{Tf}_{2} \mathrm{~N}\right]$ spectrum. Earlier studies of nitric acid dissolution of $\mathrm{UO}_{2}$ in [BMIM] $\left[\mathrm{Tf}_{2} \mathrm{~N}\right.$ ] using UV-Vis, EXAFS (extended X-ray absorption fine structure), and molecular dynamic simulation show the existence of a uranyl nitrato species $\mathrm{UO}_{2}\left(\mathrm{NO}_{3}\right)_{3}{ }^{-}$in the ionic liquid phase with excess amounts of nitrate. ${ }^{1,3,37}$ The presence of $\mathrm{UO}_{2}\left(\mathrm{NO}_{3}\right)_{3}{ }^{-}$in the IL would lead to the enhancement of absorption bands in the $420-480 \mathrm{~nm}$ range. ${ }^{1}$ These enhanced absorption bands are not observed in our IL system with $\mathrm{TBP}\left(\mathrm{HNO}_{3}\right)_{1.8}\left(\mathrm{H}_{2} \mathrm{O}\right)_{0.6}$. In our case of $\mathrm{UO}_{2}$ dissolution with a $\mathrm{TBP}\left(\mathrm{HNO}_{3}\right)_{1.8}\left(\mathrm{H}_{2} \mathrm{O}\right)_{0.6}$ complex in [BMIM] $\left.\mathrm{Tf}_{2} \mathrm{~N}\right]$, since 2 molecules of TBP are coordinated with the uranyl ion, the dissolved uranyl species is probably of the form $\mathrm{UO}_{2}(\mathrm{TBP})_{2}\left(\mathrm{NO}_{3}\right)_{x}$ where $x$ may be 1,2 or 3 . It is unlikely that the coordination number of uranium would allow formation of a uranyl-TBP-nitrate complex with $3 \mathrm{NO}_{3}{ }^{-}$. Charged $\mathrm{UO}_{2}(\mathrm{TBP})_{2}\left(\mathrm{NO}_{3}\right)^{+}$species $(x=1)$ is not extractable by supercritical $\mathrm{CO}_{2}$. Formation of neutral $\mathrm{UO}_{2}(\mathrm{TBP})_{2}\left(\mathrm{NO}_{3}\right)_{2}$ in our IL system is very likely. Neutral uranyl complexes extracted from nitric acid solutions into ionic liquids are known in the literature. ${ }^{13,17}$ However, the possibility of forming aggregates of uranyl-TBPnitrate complexes in the IL phase with different $x$ values $(x=1,2$, and 3) cannot be ruled out. It is also possible that $\mathrm{HNO}_{3}$ molecules may be attached to the uranyl-TBP-nitrate complexes forming $\mathrm{UO}_{2}(\mathrm{TBP})_{2}\left(\mathrm{NO}_{3}\right)_{x} \cdot\left(\mathrm{HNO}_{3}\right)_{y}$ adducts in the IL phase. Formation of

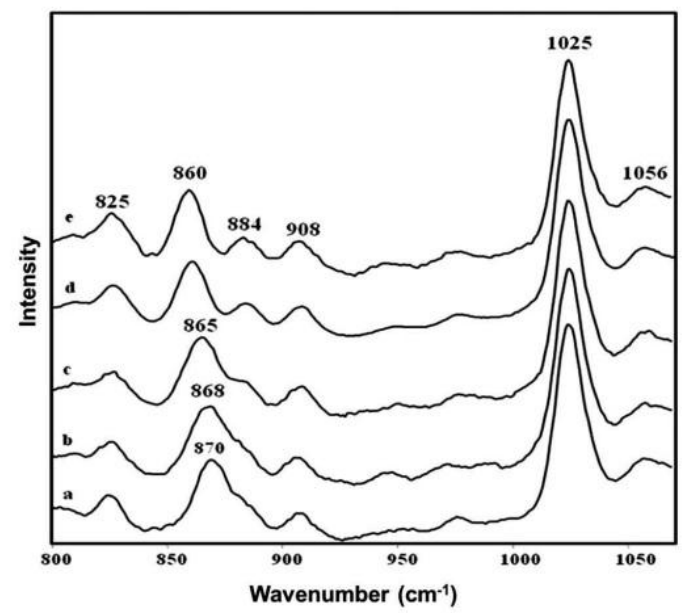

Fig. 5 Raman spectra of the IL solution with different molar ratios of $\mathrm{UO}_{2}:$ TBP (a) $1: 0.25$, (b) $1: 0.5$, (c) $1: 1$, (d) $1: 2$, and (e) $1: 3$.
$\mathrm{UO}_{2}(\mathrm{TBP})_{2}\left(\mathrm{NO}_{3}\right)_{2} \cdot \mathrm{HNO}_{3}$ in dodecane-TBP extraction of uranyl ions from high concentrations of nitric acid solutions has been reported in the literature. ${ }^{38}$ Further research is needed to fully understand nitrate and $\mathrm{HNO}_{3}$ coordination with the uranyl-TBP species dissolved in the IL system.

\section{Transferring uranium from the $\mathrm{IL}$ phase to $\mathrm{sc}-\mathrm{CO}_{2}$}

The IL containing dissolved uranium species from the cumulative $\mathrm{UO}_{2}$ dissolution experiment was placed in a high pressure fiberoptic cell connected to a CCD array UV/vis spectrometer for static supercritical fluid extraction (SFE) studies. A description of the high-pressure fiber-optic device was reported in the literature. ${ }^{39}$ The cell was preheated to $40{ }^{\circ} \mathrm{C}$ and pressurized with $200 \mathrm{~atm}$ of $\mathrm{CO}_{2}$. The SFE process was also monitored by a Raman spectrometer and the spectrum of the $\mathrm{CO}_{2}$ phase after $30 \mathrm{~min}$ of static extraction time is shown in Fig. 6a. The Raman peak at $860 \mathrm{~cm}^{-1}$ is identical to the peak position for synthesized $\mathrm{UO}_{2}\left(\mathrm{NO}_{3}\right)_{2}(\mathrm{TBP})_{2}$ dissolved directly in sc- $\mathrm{CO}_{2}$. This Raman peak in sc- $\mathrm{CO}_{2}$ is also the same as that observed for the dissolved uranyl species in the IL shown in Fig. $4 \mathrm{c}$ and Fig. 5d. The Raman study suggests $\mathrm{UO}_{2}$ dissolved in [BMIM] $\left[\mathrm{Tf}_{2} \mathrm{~N}\right]$ with $\mathrm{TBP}\left(\mathrm{HNO}_{3}\right)_{1.8}\left(\mathrm{H}_{2} \mathrm{O}\right)_{0.6}$ may exist as the neutral $\mathrm{UO}_{2}\left(\mathrm{NO}_{3}\right)_{2}(\mathrm{TBP})_{2}$ compound in the IL phase.
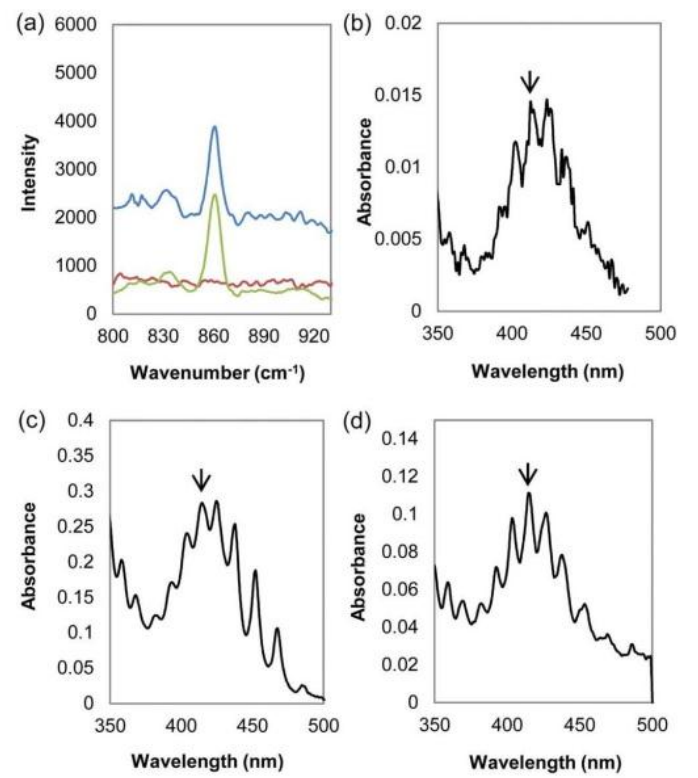

Fig. 6 (a) Raman spectra of uranyl species in sc- $\mathrm{CO}_{2}$. Red: $\mathrm{sc}-\mathrm{CO}$ background; green: standard $\mathrm{UO}_{2}\left(\mathrm{NO}_{3}\right)_{2}(\mathrm{TBP})_{2}$ dissolved in sc- $\mathrm{CO}_{2}$; blue: uranyl species extracted from [BMIM] $\left[\mathrm{Tf}_{2} \mathrm{~N}\right]$ into sc- $\mathrm{CO}_{2}$ (30 min of static extraction at $40^{\circ} \mathrm{C}$ and $200 \mathrm{~atm}$ ); (b) in situ UV/Vis spectrum of the uranyl species extracted int o the $\mathrm{sc}-\mathrm{CO}_{2}$ phase; (c) UV/Vis spectrum of the uranyl species collected in an acetone trap solution; (d) UV/Vis spectrum of the uranyl species collected in a dodecane solution.

Extraction of the uranium species from the IL phase to the sc$\mathrm{CO}_{2}$ at $40^{\circ} \mathrm{C}$ and $200 \mathrm{~atm}$ is virtually complete in $<10$ min indicating the mass transfer of the uranyl complex from [BMIM] $\left[\mathrm{Tf}_{2} \mathrm{~N}\right]$ 
View Article Online

to $\mathrm{sc}-\mathrm{CO}_{2}$ phase is very rapid. Without TBP in the system, uranyl nitrate dissolved in [BMIM] $\left[\mathrm{Tf}_{2} \mathrm{~N}\right]$ is not extractable by sc- $\mathrm{CO}_{2}$. The solubility of $\mathrm{UO}_{2}\left(\mathrm{NO}_{3}\right)_{2}(\mathrm{TBP})_{2}$ in sc- $\mathrm{CO}_{2}$ at $40{ }^{\circ} \mathrm{C}$ and $200 \mathrm{~atm}$ is about 0.45 moles per litre. ${ }^{40}$ The amount of uranium and the volume of the $\mathrm{sc}-\mathrm{CO}_{2}$ extraction cell used in our experiments would not reach $10 \%$ of the solubility limit. ${ }^{40}$ Fig. $6 \mathrm{~b}$ shows the UV-Vis spectrum of the uranyl species dissolved in the supercritical fluid $\mathrm{CO}_{2}$ phase obtained using the high-pressure fiber-optic cell. The spectrum is similar to that reported in the literature for synthesized $\mathrm{UO}_{2}(\mathrm{TBP})_{2}\left(\mathrm{NO}_{3}\right)_{2}$ in sc- $\mathrm{CO}_{2}{ }^{40}$ except the intensities of the peaks at $425 \mathrm{~nm}$ and above are enhanced. The enhanced peak intensities in this region may be attributed to the formation of an $\mathrm{HNO}_{3}$ adduct such as $\mathrm{UO}_{2}(\mathrm{TBP})_{2}\left(\mathrm{NO}_{3}\right)_{2} \cdot \mathrm{HNO}_{3}$ as observed in the solvent extraction experiments. ${ }^{38}$ The uranyl species extracted into $\mathrm{sc}-\mathrm{CO}_{2}$ can be recovered by depressurizing the exit fluid and collected in an acetone trap solution. The UVVis spectrum of the acetone trap solution shown in Fig. $6 \mathrm{c}$ is similar to that found in the $\mathrm{sc}-\mathrm{CO}_{2}$ phase. When the acetone trap solution was evaporated to near dryness in a beaker and dodecane and water were added, the absorption spectrum of the dodecane phase was identical to that of $\mathrm{UO}_{2}(\mathrm{TBP})_{2}\left(\mathrm{NO}_{3}\right)_{2}$ (Fig. 6d) ${ }^{38}$ and the aqueous phase was acidic. In addition, FT-IR spectra reveal that the $\mathrm{HNO}_{3}$ adduct peak $\left(1648 \mathrm{~cm}^{-1}\right)$ observed in the acetone trap solution was absent in the dodecane trap solution (see the $\mathrm{ESI}^{\dagger}$ ). The $\mathrm{UO}_{2}(\mathrm{TBP})_{2}\left(\mathrm{NO}_{3}\right)_{2} \cdot \mathrm{HNO}_{3}$ adduct is known to be unstable in contact with organic phase and/or water according to the literature. ${ }^{38}$ When the exit fluid was bubbled through a water-dodecane trap solution, the uranyl species collected in the dodecane phase showed an absorption spectrum identical to that of Fig. $6 \mathrm{~d}$.

\section{Conclusion}

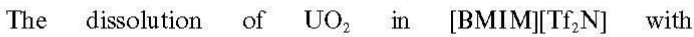
$\mathrm{TBP}\left(\mathrm{HNO}_{3}\right)_{1.8}\left(\mathrm{H}_{2} \mathrm{O}\right)_{0.6}$ at room temperature follows pseudo first-order kinetics initially. The maximum amount of $\mathrm{UO}_{2}$ dissolution is about $320 \mathrm{mg}$ in $3.6 \mathrm{~mL}$ of [BMIM][Tf $\mathrm{T}_{2} \mathrm{~N}$ ] containing $16.7 \%$ by volume of the $\operatorname{TBP}\left(\mathrm{HNO}_{3}\right)_{1.8}\left(\mathrm{H}_{2} \mathrm{O}\right)_{0.6}$ complex. Raman spectra show the dissolved uranyl species is coordinated with TBP in the IL phase with a uranyl: TBP molar ratio of $1: 2$ suggesting the formation of uranyl-TBP complexes of a general form $\mathrm{UO}_{2}(\mathrm{TBP})_{2}\left(\mathrm{NO}_{3}\right)_{x}$ where $x$ may be 1,2 , or 3 . The uranium species dissolved in the IL can be rapidly extracted into $\mathrm{sc}_{-} \mathrm{CO}_{2}$. UV-Vis spectra indicate the presence of a $\mathrm{UO}_{2}\left(\mathrm{NO}_{3}\right)_{2}(\mathrm{TBP})_{2}$ and $\mathrm{HNO}_{3}$ adduct probably of the form $\mathrm{UO}_{2}\left(\mathrm{NO}_{3}\right)_{2}(\mathrm{TBP})_{2} \cdot \mathrm{HNO}_{3}$. The $\mathrm{HNO}_{3}$ adduct dissociates in contact with a water-dodecane trap solution during depressurization of the system. The uranyl species collected in the dodecane phase is $\mathrm{UO}_{2}\left(\mathrm{NO}_{3}\right)_{2}(\mathrm{TBP})_{2}$. No aqueous phase is formed either in the IL dissolution step or in the sc- $\mathrm{CO}_{2}$ extraction step. This IL-sc- $-\mathrm{CO}_{2}$ coupled dissolution/extraction process may provide a new green technique for treating uranium-containing wastes. Further research along this direction is currently in progress.

\section{Acknowledgements}

This work was supported by DOE Nuclear Energy University Program (NE-UP grant number TO 00058).

\section{References}

1 I. Billard, C. Gaillard and C. Hennig, Dalton Trans., 2007, 4214 4221.

2 I. Billard and C. Gaillard, Radiochim. Acta, 2009, 97, 355359 .

3 J. S. Wang, C. N. Sheaff, B. Yoon, R. S. Addleman and C. M. Wai, Chem.-Eur. J., 2009, 15, 4458-4463.

4 M. L. Dietz and J. A. Dzielawa, Chem. Commun., 2001, 2124 2125.

5 M. L. Dietz, J. A. Dzielawa, I. Laszak, B. A. Young and M. P. Jensen, Green Chem., 2003, 5, 682-685.

6 D. C. Stepinski, M. P. Jensen, J. A. Dzielawa and M. L. Dietz, Green Chem., 2005, 7, 151-158.

7 M. L. Dietz and D. C. Stepinski, Green Chem., 2005, 7, 747750 .

8 M. L. Dietz, Sep. Sci. Technol., 2006, 41, 2047-2063.

9 M. L. Dietz and D. C. Stepinski, Talanta, 2008, 75, 598603.

10 M. P. Jensen, J. A. Dzielawa, P. Rickert and M. L. Dietz, J. Am. Chem. Soc., 2002, 124, 10664-10665.

11 A. E. Visser, M. P. Jensen, I. Laszak, K. L. Nash, G. R. Choppin and D. R. Rogers, Inorg. Chem. Commun., 2003, 21972199.

12 A. E. Visser and R. D. Rogers, J. Solid State Chem., 2003, 171, 109 113

13 V. A. Cocalia, M. P. Jensen, J. D. Holbrey, S. K. Spear, D. C. Stepinski and R. D. Rogers, Dalton Trans., 2005, 1966-1971.

14 V. A. Cocalia, K. E. Gutowski and R. D. Rogers, Coord. Chem. Rev, 2006, 250, 755-764.

15 K. E. Gutowski, V. A. Cocalia, S. T. Griffin, N. J. Bridges, D. A. Dixon and R. D. Rogers, J. Am. Chem. Soc., 2007, 129, 526536.

16 P. Giridhar, K. A. Venkatesan, T. G. Srinivasan and P. R. V. Rao, $J$. Nucl. Radiochem. Sci., 2004, 5, 21-26.

17 P. Giridhar, K. A. Venkatesan, T. G. Srinivasan and P. R. V. Rao, $J$. Radioanal. Nucl. Chem., 2005, 265, 31-38.

18 P. Giridhar, K. A. Venkatesan, S. Subramaniam, T. G. Srinivasan and P. R. V. Rao, J. Alloys Compd., 2008, 104-108.

19 D. Allen, G. Baston, A. E. Bradley, T. Gorman, A. Haile, I. Hamblett, J. E. Hatter, M. J. F. Healey, B. Hodgson, R. Lewin, K. V. Lovell, B. Newton, W. R. Pitner, D. W. Rooney, D. Sanders, K. R. Seddon, H. E. Sims and R. C. Thied, Green Chem., 2002, 4, 152158

20 S. Dai, Y. H. Ju and C. E. Barnes, J. Chem. Soc., Dalton Trans., 1999, 1201-1202.

21 S. I. Nikitenko and P. Moisy, Inorg. Chem., 2006, 45, 12351242.

22 R. D. Rogers and K. R. Seddon, American Chemical Society. Division of Industrial and Engineering Chemistry. and American Chemical Society. Meeting, Ionic liquids: industrial applications for green chemistry, American Chemical Society, Washington, D.C., 2002 .

23 A. Ouadi, O. Klimchuk, C. Gaillard and I. Billard, Green Chem., 2007, 9, 1160-1162.

24 I. L. Odinets, E. V. Sharova, O. I. Artyshin, K. A. Lyssenko, Y. V. Nelyubina, G. V. Myasoedova, N. P. Molochnikova and E. A. Zakharchenro, Dalton Trans., 2010, 39, 4170-4178.

25 J. F. Wishart and I. A. Shkrob, ACS Symp. Ser, 2009, 1030, 119134.

26 K. Binnemans, Chem. Rev., 2007, 107, 2592-2614

27 L. A. Blanchard, D. Hancu, E. J. Beckman and J. F. Brennecke, Nature, 1999, 399, 28-29.

28 A. E. Bradley, C. Hardacre, M. Nieuwenhuyzen, W. R. Pitner, D. Sanders, K. R. Seddon and R. C. Thied, Inorg. Chem., 2004, 43, 25032514.

29 D. L. Quach, C. M. Wai and S. P. Pasilis, Inorg. Chem., 2010, 49, 8568-8572.

30 Y. Enokida, O. Tomioka, S. C. Lee, A. Rustenholtz and C. M. Wai, Ind. Eng. Chem. Res., 2003, 42, 5037-5041.

31 Y. Ikeda, Y. Yasuike, K. Nishimura, S. Hasegawa and Y. Takashima, $J$. Nucl. Mater., 1995, 224, 266-272.

32 S. Georg, I. Billard, A. Ouadi, C. Gaillard, L. Petitjean, M. Picquet and V. Solov'ev, J. Phys. Chem. B, 2010, 114, 4276-
4282 . 
View Article Online

$33 \mathrm{~K}$. Servaes, C. Hennig, I. Billard, C Gaillard, K. Binnemans, C Gorller-Walrand and R. Van Deun, Eur. J. Inorg. Chem., 2007, 51205126

34 E. R. Talaty, S. Raja, V. J. Storhaug, A. Dolle and W. R. Carper, $J$ Phys. Chem. B, 2004, 108, 13177-13184

35 C. Nguyen-Trung, D. A. Palmer, G. M. Begun, C. Peiffert and R. E. Mesmer, J. Solution Chem., 2000, 29, 101-129.

36 M. H. Brooker, C. H. Huang and J. Sylwestrowicz, J. Inorg. Nucl. Chem. 1980, 42, 1431-1440.
37 C. Gaillard, A. Chaumont, I. Billard, C. Hennig, A. Ouadi and G Wipff, Inorg. Chem., 2007, 46, 4815-4826.

38 R. Chiarizia, M. P. Jensen, M. Borkowski, J. R. Ferraro, P. Thiyagarajan and K. C. Littrell, Solvent Extr. Ion Exch., 2003, 21, 1 27.

39 F. Hunt, H. Ohde and C. M. Wai, Rev. Sci. Instrum., 1999, 70, 46614667.

40 M. J. Carrott, B. E. Waller, N. G. Smart and C. M. Wai, Chem Commun., 1998, 373-374. 
Solvent Extraction and Ion Exchange, 30: 735-747, 2012

Copyright (C) Taylor \& Francis Group, LLC

ISSN: 0736-6299 print / 1532-2262 online

DOI: $10.1080 / 07366299.2012 .700583$

\title{
THE PARTITIONING OF AMERICIUM AND THE LANTHANIDES USING TETRABUTYLDIGLYCOLAMIDE (TBDGA) IN OCTANOL AND IN IONIC LIQUID SOLUTION
}

\author{
M. E. Mincher, D. L. Quach, Y. J. Liao, B. J. Mincher, \\ and C. M. Wai \\ Department of Chemistry, University of Idaho, Moscow, Idaho \\ and Idaho National Lab, Idaho Falls, Idaho
}

Separations among the lanthanides and the separation of Am from the lanthanides remain challenging, and research in this area continues to expand. The separation of adjacent lanthanides is of interest to high-tech industries because individual lanthanides have specialized uses and are in short supply. In nuclear fuel cycle applications Am would be incorporated into fast-reactor fuels, yet the lanthanides are not desired. In this work, the diglycolamide $\mathbf{N}, \mathbf{N}, \mathbf{N}^{\dagger}, \mathbf{N}^{\dagger}$-tetrabutyldiglycolamide (TBDGA) was investigated as a ligand for lanthanide and Am solvent extraction in both molecular and room-temperature-ionic-liquid (RTIL) diluents.The RTIL [ $\left.\mathrm{C}_{4} M I M I I T f_{2} \mathrm{~N}\right]$ showed very high extraction efficiency for these trivalent metals from low nitric acid concentrations, while the molecular diluent 1-octanol showed high extraction efficiency at high acid concentrations. This was attributed to the extraction of ionic nitrate complexes by the $R T I L$, whereas 1 -octanol extracted neutral nitrate complexes. TBDGA in RTIL did not provide adequate separation factors for Am/lanthanide partitioning, but 1-octanol did show reasonable separation possibilities. Lanthanide intergroup separations appeared to be feasible in both diluents, but with higher separation factors from 1-octanol.

Keywords: Americium, lanthanides, ionic liquids, diglycolamides

\section{INTRODUCTION}

Separations among the lanthanides and the partitioning of Am from the lanthanides are challenging. The ubiquitous trivalent oxidation state and the narrow range of ionic radii of these metals limit the options available to design such separations. Yet the separation of the adjacent lanthanides is of current industrial interest, with these elements being of limited supply and having strategic uses in catalysts, phosphors, lasers, and magnets. The Am separation is of interest in nuclear fuel cycle applications, where current proposed reprocessing schemes would separate Am for incorporation into fast-reactor fuels, with disposal of the lanthanides as radioactive fission-product waste.

Past attempts at the Am separation have been made using soft-donor ligands to preferentially complex the actinide, ${ }^{[1]}$ or less commonly by adjusting the americium valence state. ${ }^{[2]}$ However, within the lanthanide series redox chemistry is seldom available and

Address correspondence to B. J. Mincher, Department of Chemistry, University of Idaho, Moscow, Idaho 83844 and Idaho National Lab, Idaho Falls, Idaho 83415. E-mail: bruce.mincher@in1.gov 
lanthanide/lanthanide separations have relied mainly on the small differences in charge density along the lanthanide contraction. Among the common ligands used in $f$-element solvent extraction, the diamides have received increasing attention. ${ }^{[3]}$ For example, European proposals for actinide/lanthanide solvent extraction for nuclear fuel cycle applications are based on the diamide dimethyl dioctyl hexylethoxymalonamide (DMDOHEMA) in the DIAMEX process. ${ }^{[4]}$ Some diamide compounds provide high inherent separation factors $\left(\alpha_{\mathrm{Am} / \mathrm{Eu}}\right)$ without valence-state adjustments, possibly due to their potential $N$-donor capacity. For example, Paulenova et al. reported $\alpha_{\mathrm{Am} / \mathrm{Eu}}$ as high as $\sim 6$ using ethyl(tolyl)diamides of dipicolinic acid in phenyltrifluoromethylsulfone diluent for extractions from $1 \mathrm{M}$ $\mathrm{HNO}_{3} \cdot{ }^{[5]}$ Sasaki et al. evaluated six compounds of the general structure R,R-N-CO-CH${ }_{2}^{-}$ $\mathrm{O}-\mathrm{CH}_{2}-\mathrm{CO}-\mathrm{N}-\mathrm{R}, \mathrm{R}$ (diglycolamides) and reported that the order of extraction efficiency for the actinides was $\mathrm{An}(\mathrm{III}) / \mathrm{An}(\mathrm{IV})>\mathrm{An}(\mathrm{VI})>\mathrm{An}(\mathrm{V})$ and that the heavier lanthanides were preferentially extracted over the lighter ones ${ }^{[6]}$ When the alkyl chain length of the $\mathrm{R}$-group was varied in that work, shorter chain lengths provided higher metal solvent extraction distribution ratios. Gujar et al. compared a diglycolamide containing $n$-octyl R-groups with one containing branched-chain 2-ethylhexyl groups and concluded that the branchedchain compound was less basic and provided lower americium and neodymium distribution ratios. ${ }^{[7]}$

The diglycolamide containing $n$-octyl groups is $N, N, N^{\prime}, N^{\prime}$-tetraoctyldiglycolamide (TODGA). This compound has been evaluated for its potential utility in fuel-cycle separations. ${ }^{[8,9]}$ The goal of that work was to illustrate high extraction efficiency for the $f$ elements, rather than $f$-element intergroup separations. However, Horwitz et al. performed a characterization of TODGA as a lanthanide and actinide complexing agent immobilized on an extraction chromatographic resin. ${ }^{[10]}$ The possibility that such columns could be used to separate adjacent lanthanides was suggested in that work.

The room-temperature ionic liquids (RTILs) are currently under investigation as solvent extraction diluents for radiochemical separations. Several recent reports indicate increased extraction efficiency when switching diluents from the conventional molecular solvents such as octanol to ionic liquids such as 1-butyl-3methylimidizolium bis(trifluoromethylsulfonyl)-imide $\left[\mathrm{C}_{4} \mathrm{MIM}\right]\left[\mathrm{Tf}_{2} \mathrm{~N}\right]$, often also referred to as $[\mathrm{BMIM}]\left[\mathrm{NTf}_{2}\right]{ }^{[11,}{ }^{12]}$ This is thought to be due to a change in the mechanism of extraction from the partitioning of the neutral metal complex in the conventional molecular solvent to ionic species in the RTIL solvent. ${ }^{[13,14,15]}$ This ion-exchange mechanism results in a post-extraction aqueous phase contaminated with RTIL ions, ${ }^{[14]}$ and this has been advanced as a serious drawback to the use of RTILs in solvent extraction. ${ }^{[16]}$ However, given the high extraction efficiencies obtained and other RTIL advantages including nearzero vapor pressures and their non-flammable nature, it is unlikely that this will negate the continued investigation of their potential in radiochemical separations. For example, very recently high separation factors for Am/Eu were reported using phosphoric acid extractants in an RTIL with an aqueous phase containing DTPA, ${ }^{[17]}$ in a TALSPEAK-like partitioning scheme. ${ }^{[1]}$ The extraction of actinides, lanthanides, and fission products into RTILs was recently reviewed. ${ }^{[18]}$

The research presented here characterized the shorter alkyl-chain length diglycolamide $N, N, N^{\prime}, N^{\prime}$-tetrabutyldiglycolamide (TBDGA) as a ligand for Am and lanthanide separations using the molecular diluent 1-octanol. We compared these results to TBDGA extraction in the RTIL $\left[\mathrm{C}_{4} \mathrm{MIM}\right]\left[\mathrm{Tf}_{2} \mathrm{~N}\right]$. The highest extraction efficiency was found for the extraction of cationic nitrato-species into the RTIL; however, higher separation factors for lanthanide and Am/lanthanide separations were achieved in the molecular solvent. 


\section{EXPERIMENTAL}

\section{Synthesis of TBDGA}

The structure of TBDGA is shown in Fig. 1. It was prepared according to the method given in reference [19]. The product was characterized by NMR and IR spectroscopy. ${ }^{1} \mathrm{H}$ NMR (Bruker $300 \mathrm{MHz}, \mathrm{CDCl}_{3}$ ) showed $8: 0.90-0.96(\mathrm{~m}, 12 \mathrm{H}), 1.33$ (sextet, $J=7.2 \mathrm{~Hz}$, $8 \mathrm{H}$ ), 1.51 (quintet, $J=7.2 \mathrm{~Hz}, 8 \mathrm{H}$ ), 3.21 (triplet, $J=7.5 \mathrm{~Hz}, 4 \mathrm{H}$ ), 3.32 (triplet, $J=7.5 \mathrm{~Hz}$, $4 \mathrm{H}), 4.33$ (singlet, $4 \mathrm{H})$. IR spectrum: $1653 \mathrm{~cm}^{-1}(\mathrm{C}=\mathrm{O})$.

\section{Synthesis of [ $\left.\mathrm{C}_{4} \mathrm{MIM}\right]\left[\mathrm{Tf}_{2} \mathrm{~N}\right] \mathrm{RTIL}$}

The RTIL was prepared according to Huddleston et al. ${ }^{[20]}$ The chloride ion content of the product was measured by NAA to be $<10 \mathrm{ppm}$. The yield of the ionic liquid was around 70 to $80 \% .{ }^{1} \mathrm{H}-\mathrm{NMR}$ (Bruker $300 \mathrm{MHz}, \mathrm{CDCl}_{3}$ ) showed $\delta: 8.78$ (singlet, $1 \mathrm{H}$ ), 7.30 (multiplet, 2H), 4.19 (triplet, $J=7.4 \mathrm{~Hz}, 2 \mathrm{H}$ ), 3.96 (singlet, 3H), 1.89 (multiplet, 2H), 1.37 (multiplet, 2H), 0.98 (triplet, $J=7.2 \mathrm{~Hz}, 3 \mathrm{H}$ ).

\section{Solvent Extraction Experiments}

We performed solvent extraction experiments over a range of aqueous-phase acidities using pre-equilibrated $0.007 \mathrm{M}$ TBDGA in 1-octanol or $\left[\mathrm{C}_{4} \mathrm{MIM}\right]\left[\mathrm{Tf}_{2} \mathrm{~N}\right]$ solution. Extractions were performed at room temperature $\left(19 \pm 2{ }^{\circ} \mathrm{C}\right)$, equal-volume, one-minute contacts traced with ${ }^{139} \mathrm{Ce},{ }^{154} \mathrm{Eu}$, and/or ${ }^{243} \mathrm{Am}$, or with $100 \mathrm{ppb}$ standard solutions of stable lanthanides, as appropriate. The phases were shaken by hand for $1 \mathrm{~min}$. in $10 \mathrm{~mL}$ glass culture tubes and then separated by centrifugation for $2 \mathrm{~min}$. Aliquots of each phase were next removed from the culture tube by a Pasteur pipet into $5 \mathrm{~mL}$ disposable beakers, taking care to avoid phase cross-contamination. Then, $1 \mathrm{~mL}$ of each phase was pipetted from the disposable beaker, again avoiding cross contamination, into a $20 \mathrm{~mL}$ glass scintillation vial. These samples were then analyzed by $\gamma$-ray counting for the radiotracers or by ICP-MS for the stable lanthanides. The distribution ratios were reported as the mean ratios of the activity or concentration in organic: aqueous phases $\pm 1 \sigma$, as a relative standard deviation for

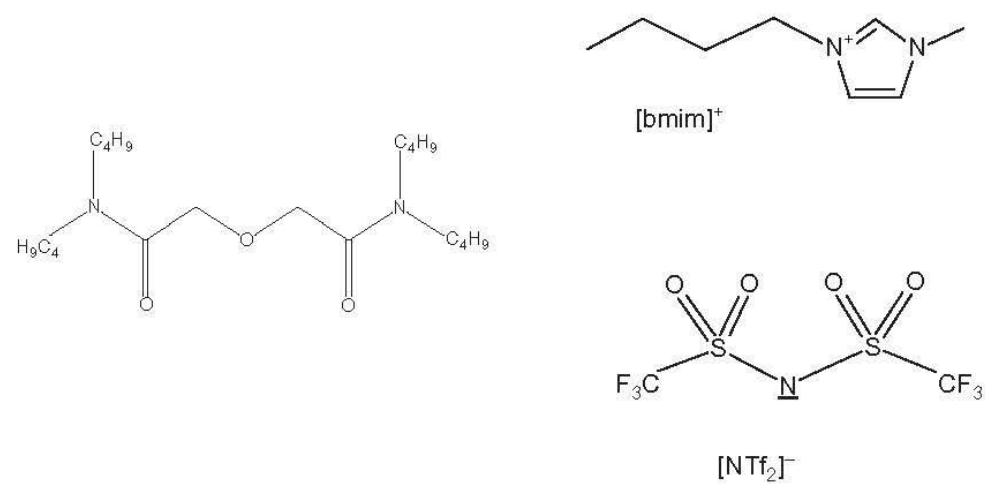

Figure 1 Structure of the diglycolamide ligand $N, N, N^{\prime}, N^{\prime}$-tetrabutyldiglycolamide (TBDGA) (left) and the roomtemperature ionic liquid 1-butyl-3-methylimidizolium bis(trifl uoromethylsulfonyl)-imide [ $\left.\mathrm{C}_{4} \mathrm{MIM}\right]\left[\mathrm{Tf}_{2} \mathrm{~N}\right]$ (right). 
replicate determinations. An initial series of extractions using $10 \mathrm{~s}, 30 \mathrm{~s}$, and $60 \mathrm{~s}$ contact times for TBDGA/octanol extractions from $4 \mathrm{M} \mathrm{HNO}_{3}$ was performed to verify that equilibrium was achieved within the $1 \mathrm{~min}$. contacts used in the actual measurements. This showed fast kinetics, with the equilibrium distribution ratios achieved in $<10 \mathrm{~s}$, with $D_{\mathrm{Am}}$ and $D_{\mathrm{Eu}}$ values well within experimental error versus contact time.

For the determination of stable lanthanide distribution ratios, $100 \mathrm{ppm}$ standard lanthanide stock solution (Fischer Scientific) was diluted to $100 \mathrm{ppb}$ in the appropriate nitric acid concentration. The resulting total metal concentration was $\sim 10 \mathrm{mM}$. The distribution ratios were calculated by difference after measuring the post-extraction aqueous phase by ICP-MS.

\section{RESULTS AND DISCUSSION \\ TBDGA Separations in 1-Octanol}

The extraction of the lanthanides from 1.0-8.0 $\mathrm{M} \mathrm{HNO}_{3}$ solution using $0.007 \mathrm{M}$ TBDGA in 1-octanol is shown in Fig. 2. The lanthanides may be conveniently grouped into three categories based on the results shown. The lightest lanthanides, La, Ce, Pr, and Nd were poorly extracted, all with $D_{\mathrm{Ln}}<1$ at all nitric acid concentrations. The heaviest lanthanides, $\mathrm{Tb}, \mathrm{Dy}, \mathrm{Ho}, \mathrm{Tm}, \mathrm{Yb}$, and Lu, were highly extractable, with $D_{\mathrm{Ln}}$ in the range 10-70 across this nitric acid concentration range. Finally, Sm, Eu, and Gd had intermediate behavior, with $D_{\mathrm{Ln}}$ in the range 2-5. These results suggest that TBDGA/octanol could be used to separate the lanthanides into these three classes using solvent extraction contacts. Further, the separation factors among the heavy lanthanides are such that separation of some

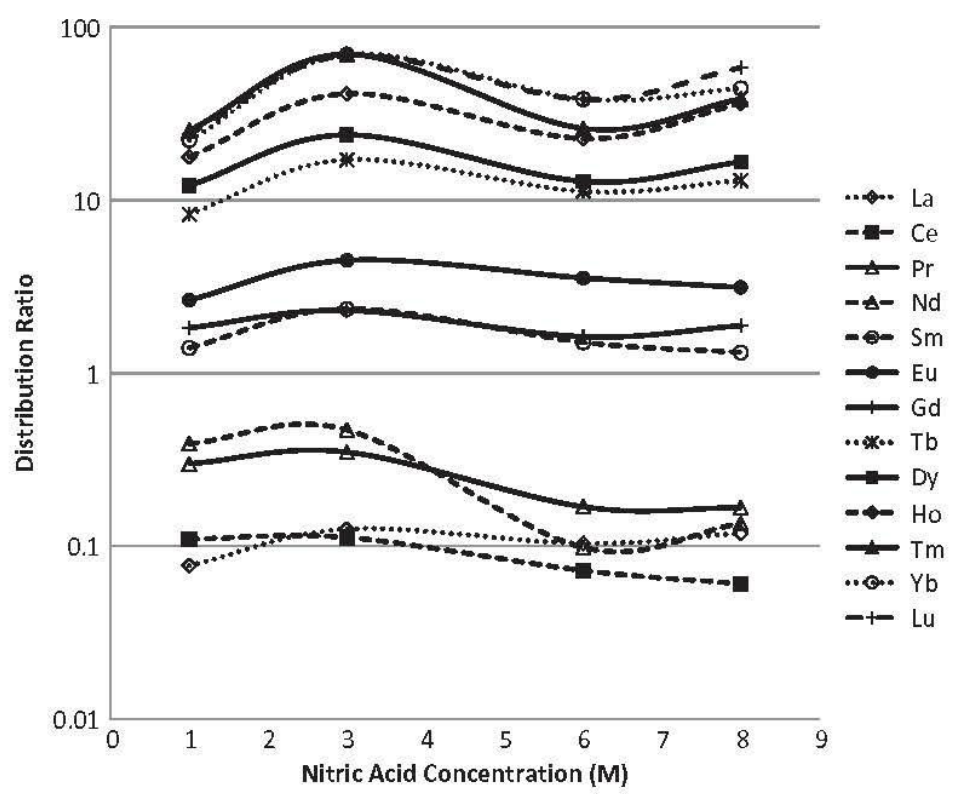

Figure 2 The solvent extraction of the lanthanides from acidic solution by $0.007 \mathrm{M}$ TBDGA in 1-octanol. The aqueous phase consisted of $100 \mathrm{ppb}$ of each metal ( $\sim 10 \mathrm{mM}$ total). The distribution ratios are the mean values of duplicate extractions with an average error of $\pm 2.5 \%$. 
of these metals from each other would be possible, especially using TBDGA on an inert support in column chromatography. For example, in $3 \mathrm{M} \mathrm{HNO}_{3}$ as shown in Fig. 2, the separation factor $\alpha_{\mathrm{Lu} / \mathrm{La}}$ is $\sim 550$; the separation factor $\alpha_{\mathrm{Lu} / \mathrm{Sm}}$ is $\sim 29$; and the separation factor $\alpha_{\mathrm{Lu} / \mathrm{Tb}}$ is $\sim 4$, for a single extraction. However, $\mathrm{Yb}$ and $\mathrm{Lu}$ have nearly identical distribution ratios at all acidities.

Since Am separation is of special interest in fuel-cycle applications, a similar extraction profile using radio-traced aqueous phases is shown in Fig. 3 for the actinide. It can be seen that at radiotracer concentration Am extraction behavior is similar to that of the intermediate lanthanides. The extraction efficiency of radiotracer $\mathrm{Eu}$ is shown for comparison and is higher than for Am; a separation factor $\alpha_{\mathrm{Eu} / \mathrm{Am}}$ of 5.4 from $2 \mathrm{M} \mathrm{HNO}_{3}$ and 11 from $6 \mathrm{M} \mathrm{HNO}_{3}$ may be calculated. For extractions using the stable lanthanide solution, the total metal concentration was in excess of the ligand concentration, and it can be seen that the $D_{\mathrm{Eu}}$ from the tracer solution $\left(D_{\mathrm{Eu}}=7.4\right.$ at $\left.6 \mathrm{M} \mathrm{HNO}_{3}\right)$ was higher than from the lanthanide solution $\left(D_{\mathrm{Eu}}=3.5\right.$ at $\left.6 \mathrm{M} \mathrm{HNO}_{3}\right)$, due to metal loading of the ligand in the lanthanide solution. For both the actinide and the lanthanides, the distribution ratios increased rapidly with nitric acid concentration until they leveled off at high acid concentrations.

This pattern is often seen for metal extraction into molecular solvents by neutral complex formation. Extraction is facilitated by nitrate anion neutralization of the extracted metal cation complex, resulting in efficient extraction into the molecular neutral diluent. At the highest nitric acid concentrations, the distribution ratios no longer increase, and this is usually attributed to competition for the ligand by nitric acid complexation. The extraction of a neutral metal complex is shown in Eq. (1), where the organic-phase species are shown in italics:

$$
\mathrm{M}^{3+}+n T B D G A+3 \mathrm{NO}_{3}^{-} \rightarrow M \bullet(T B D G A)_{n} \bullet\left(N_{3}\right)_{3}
$$

The value of $n$ was determined by Sasaki et al. ${ }^{[6]}$ to be $\sim 4$ for the Am and $\mathrm{Cm}$ complexes of TODGA using dodecane as the diluent, while Shimojo et al. ${ }^{[15]}$ reported $n=3$ for La and $n=4$ for Eu and Lu TODGA complexes in isooctane. The preferred extraction of Eu over Am suggests that $N$-donor complexation is not important for this diamide, since soft

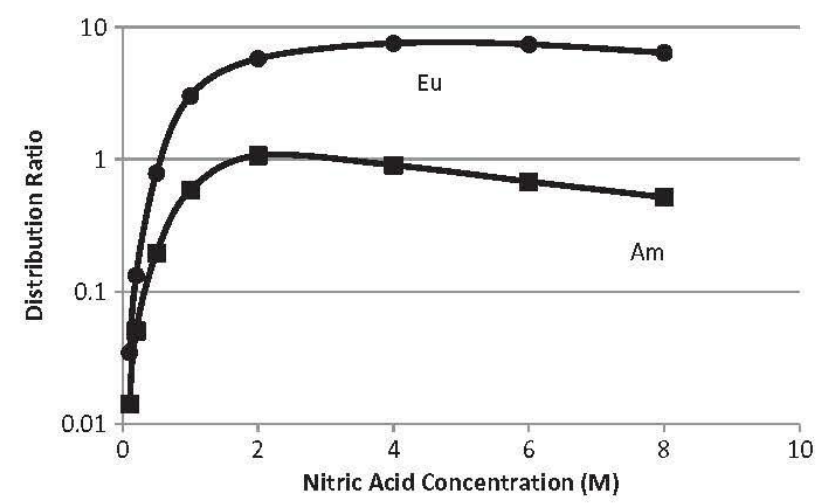

Figure 3 The solvent extraction of Am (III) and Eu (III) radiotracers from acidic solution by 0.007 M TBDGA in 1-octanol. The distribution ratios are the mean values of duplicate extractions with an average error of $\pm 10 \%$. The average mass balance was $0.979 \pm 0.08$. 


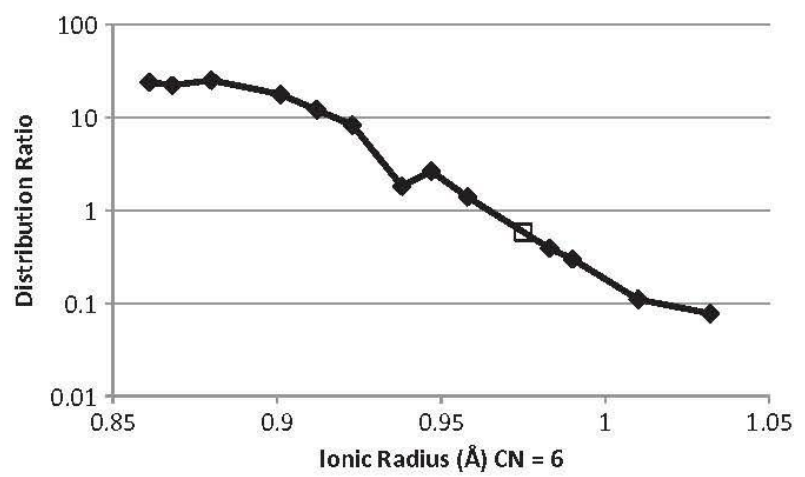

Figure 4 TBDGA solvent extraction distribution ratios from $1 \mathrm{MHNO}_{3}$ for the lanthanides and Am (open square) as a function of ionic radius for extractions in 1-octanol. Radii are those of [22].

donors prefer complexation with the actinides over the lanthanides. Oxygen donors are less selective. ${ }^{[1]}$

It should be noted that an increase in extraction efficiency was measured here for some lanthanides at nitric acid concentrations above $6 \mathrm{M}$ (Fig. 2). A similar increase in $D_{\mathrm{Am}}$ at very high acidity has previously been reported for extraction of neutral complexes with octylphenyl- $N, N$-diisobutylcarbamoylmethylphosphine oxide (CMPO), although the reason has never been adequately explained. ${ }^{[21]}$

The distribution ratios for these lanthanides and $\mathrm{Am}$ are plotted versus their ionic radii in Fig. 4, for extractions with $0.007 \mathrm{M}$ TBDGA in octanol from $1 \mathrm{M} \mathrm{HNO}_{3}$. It can be seen that the extraction efficiency rapidly increased for the heavier, lower radius trivalent lanthanide ions. This pattern suggests that extraction efficiency is related to the increasing charge density on the metal ion, as the radius decreases along the lanthanide contraction and stronger ligand complexes are formed. Americium fits the trend of the lanthanides well, although its distribution ratio was generated at the radiotracer concentration of metal. This trend is nearly identical to that reported for TODGA in dodecane by Sasaki et al., ${ }^{[6]}$ and for TODGA in isooctane by Shimojo et al., ${ }^{[15]}$ including the discontinuity between $\mathrm{Tb}$ and $\mathrm{Gd}$. Discontinuities at $\mathrm{Gd}$ are commonly seen in trends along the lanthanide series, representing extra stability imparted by the half-filled $4 f$ orbital. These data are consistent with that known for many ligands of the extraction of a neutral complex into a molecular diluent.

\section{TBDGA Separations in RTIL}

Occasionally it has been found that RTILs extract metal ions in the absence of a ligand. ${ }^{[18]}$ An initial set of extractions was performed here to evaluate the potential of ligand-free $\left[\mathrm{C}_{4} \mathrm{MIM}\right]\left[\mathrm{Tf}_{2} \mathrm{~N}\right]$ to extract lanthanide cations. Over the nitric acid concentration range 1-8 M, no extraction of the lanthanides was measured. The $D_{\mathrm{Ln}}$ were calculated by mass balance, based on the concentrations measured by mass spectrometry in the aqueous phase. Based on the average detection limit across the lanthanide series, the distribution ratio for the lanthanides for extraction into pure RTIL across the entire acid concentration range was $<1.4 \times 10^{-5}$.

The RTIL $\left[\mathrm{C}_{4} \mathrm{MIM}\right]\left[\mathrm{Tf}_{2} \mathrm{~N}\right]$ has been investigated as a solvent extraction diluent for numerous ligands. Radiotracer level $\mathrm{Am}$ and Eu extractions were performed here using 


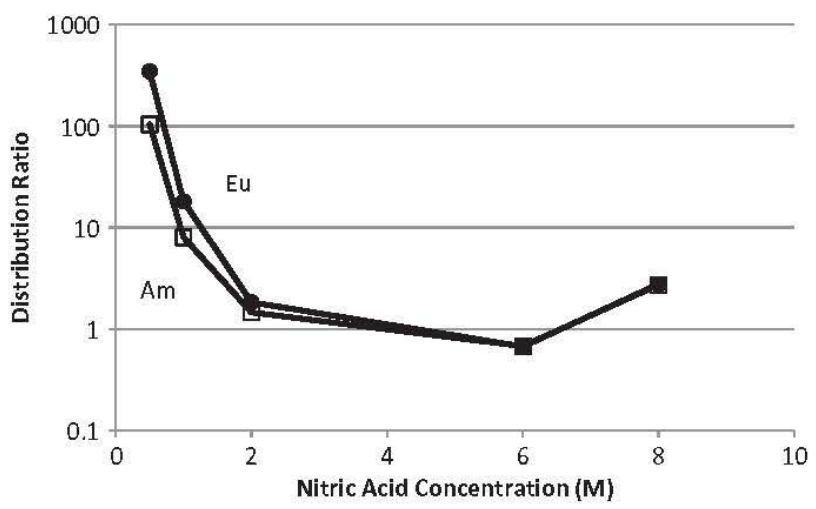

Figure 5 The extraction of Am and Eu radiotracers from acidic solution by $0.007 \mathrm{M}$ TBDGA in $\left[\mathrm{C}_{4} \mathrm{MIM}\right]\left[\mathrm{Tf}_{2} \mathrm{~N}\right]$. The distribution ratios are the mean values of duplicate extractions with an average error of $\pm 10 \%$. The average mass balance was $0.690 \pm 0.03$.

TBDGA at $0.007 \mathrm{M}$ in $\left[\mathrm{C}_{4} \mathrm{MIM}\right]\left[\mathrm{Tf}_{2} \mathrm{~N}\right]$ solution, in analogy with the data shown for 1octanol, and the results are shown in Fig. 5. The solvent extraction profile in the ionic liquid is different than in octanol, with the highest distribution ratios found at low nitric acid concentrations. Extractions from $0.5 \mathrm{M} \mathrm{HNO}_{3}$ provided much higher $D_{\mathrm{Am}}$ and $D_{\mathrm{Eu}}$ than were achieved by the same TBDGA concentration in 1-octanol at any acidity, but provide a separation factor $\alpha_{\mathrm{Eu} / \mathrm{Am}}$ of only $\sim 3.3$. The distribution ratios from $0.1 \mathrm{M} \mathrm{HNO}_{3}$ were too high to measure, as the activity of both metals was quantitatively extracted. They dropped rapidly with increasing acidity, until $D<1$ for both metals at $4 \mathrm{M} \mathrm{HNO}_{3}$. This was followed by a slight increase in distribution ratios above $6 \mathrm{M} \mathrm{HNO}_{3}$. Similar results were found when the entire lanthanide series at $100 \mathrm{ppb}$ was extracted into $0.007 \mathrm{M} \mathrm{TBDGA} /\left[\mathrm{C}_{4} \mathrm{MIM}\right]\left[\mathrm{Tf}_{2} \mathrm{~N}\right]$. These results are shown in Fig. 6. However, it can be seen that for the lightest lanthanides $\mathrm{La}, \mathrm{Ce}$, and Pr extraction efficiency did not increase at high nitric acid concentrations.

High extraction efficiencies have previously been reported for RTIL diluents, and have been considered as evidence that the extracted species is ionic, rather than neutral. ${ }^{[11}$, ${ }^{12,}{ }^{13]}$ For example, Visser and Rogers ${ }^{[23]}$ and Nakashima et al. ${ }^{[24]}$ have reported more efficient extraction of lanthanides using $\mathrm{CMPO}$ in $\left[\mathrm{C}_{4} \mathrm{MIM}\right]\left[\mathrm{PF}_{6}\right]$ than in dodecane. The proposed extraction of a cationic species containing one nitrate anion is shown in Eq. (2) and must be accompanied by the transfer of RTIL cations into the aqueous phase for reasons of charge balance:

$$
\mathrm{M}^{3+}+n T B D G A+\mathrm{NO}_{3}^{-} \rightarrow\left[M \bullet(T B D G A)_{n} \bullet \mathrm{NO}_{3}\right]^{2+}
$$

Shimojo et al. also found high extraction efficiencies for $\mathrm{La}, \mathrm{Eu}$, and $\mathrm{Lu}$ at very low acidity for TODGA in the RTIL 1-ethyl-3-methylimidizolium bis(trifluoromethylsulfonyl)-imide $\left[\mathrm{C}_{2} \mathrm{MIM}\right]\left[\mathrm{Tf}_{2} \mathrm{~N}\right]$, and concluded that the cationic species $\mathrm{M}(\mathrm{TODGA})_{3}{ }^{3+}$ was extracted into the RTIL phase. ${ }^{[15]}$ When these authors replaced the nitric acid aqueous phase with sulfuric acid, they concluded that the extraction profile was similar for both anions, and this was taken as evidence that the nitrate anion was not part of the extracted complex. However, a careful inspection of the data of Shimojo et al. ${ }^{[15]}$ reveals that while the lanthanide distribution ratios decreased with both increasing nitric and sulfuric acid concentrations, 
quantitative extraction of the metals was achieved at much higher nitric acid acidities than for sulfuric acid. This is consistent with the expectations of the Hofmeister series ${ }^{[25]}$ for the preferred extraction of nitrates over sulfates, and cationic nitrato-complexes may actually have been extracted in their work. Further, cationic metal nitrato-complexes are expected to form even when the nitrate concentration is low. For example, cationic lanthanide nitrates have long been known at high lanthanide:nitrate ratios, ${ }^{[26]}$ and recently Oikawa et al. ${ }^{[27]}$ have identified $\left[\mathrm{Ln}\left(\mathrm{NO}_{3}\right)\left(\mathrm{H}_{2} \mathrm{O}\right)_{n}\right]^{2+}$ and $\left[\mathrm{Ln}\left(\mathrm{NO}_{3}\right)_{2}\left(\mathrm{H}_{2} \mathrm{O}\right)_{m}\right]^{+}$in millimolar lanthanide nitrate solutions using positive ion electrospray mass spectrometric techniques. Thus, it is reasonable to expect that cationic lanthanide nitrates are extracted into the RTIL, and that these species explain the very high distribution ratios at low acidity in Figs. 5 and 6.

With an increasing nitrate concentration at higher acidities, the extraction of these ionic species would be suppressed as the formation of neutral metal complexes becomes more prevalent (Eq. 1). Although neutral complexes are readily extractable into non-polar 1-octanol, they would be less efficiently extracted into the ionic liquid. This would explain the decreasing distribution ratios with increasing acid concentration for extractions into the RTIL, shown in Figs. 5-6. Finally, at very high nitrate concentrations, anionic metal complexes may form, and the increase in distribution ratios found here above $6 \mathrm{M} \mathrm{HNO}_{3}$ in Figs. 5-6 suggests that the extraction of anionic nitrato-metal complexes is important:

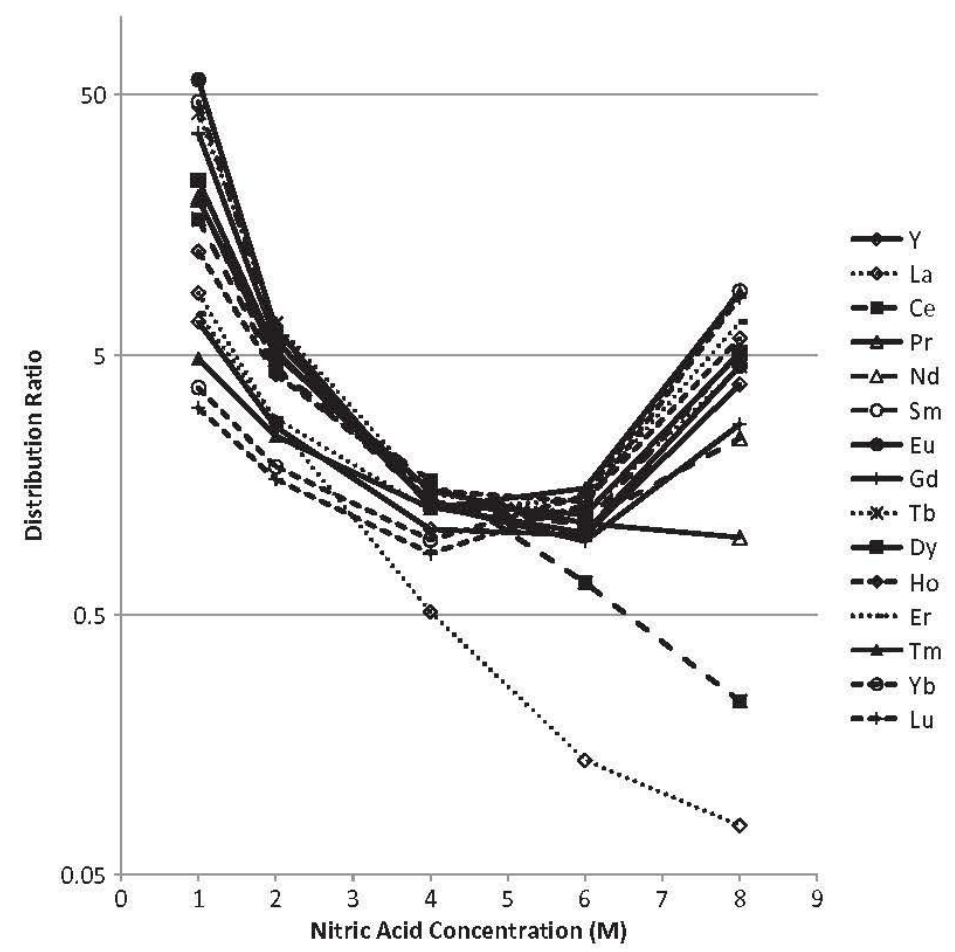

Figure 6 The RTIL extraction of the lanthanides and from acidic solution by $0.007 \mathrm{M}$ TBDGA in $\left[\mathrm{C}_{4} \mathrm{MIM}\right]\left[\mathrm{Tf}_{2} \mathrm{~N}\right]$. The distribution ratios are the mean values of duplicate extractions with an average error of $\pm 2.5 \%$. 


$$
\mathrm{M}^{3+}+n T B D G A+4 \mathrm{NO}_{3}^{-} \rightarrow\left[M \bullet(T B D G A)_{n} \bullet 4 N O_{3}\right]^{-}
$$

which again must be accompanied by transfer of RTIL anions into the aqueous phase. Shen et al. ${ }^{[28]}$ reported extraction profiles similar to ours in Figs. 5-6 for the extraction of uranyl ion into $\left[\mathrm{C}_{n} \mathrm{MIM}\right]\left[\mathrm{PF}_{6}\right]$ RTILs, using diglycolamides including TBDGA. They also concluded that extraction at low acidity was due to cation exchange; however, they concluded that an increase in $D_{\mathrm{U}}$ at high acidity was due to extraction of the neutral complex. However, the evidence we will present here supports extraction of the anion, in agreement with the findings of Rout et al. ${ }^{[29]}$ for $\mathrm{Pu}^{4+}$ extraction into imidizolium RTILs from nitrate media. While we note that cases of the extraction of neutral complexes into RTIL solvents have also been reported, ${ }^{[30-32]}$ this does not appear to be the case for our system.

The opportunity for intergroup lanthanide extractions is also evident in Fig. 6. Once again, the lanthanides may be divided into three groups based on their extraction behavior. For extractions from $1 \mathrm{M} \mathrm{HNO}_{3}$ into the RTIL, however, the poorly extracted group consisted of both heavy and light metals including $\mathrm{La}, \mathrm{Er}, \mathrm{Tm}, \mathrm{Yb}$, and $\mathrm{Lu}$. Yttrium also fell into this category. The most efficiently extracted group was $\mathrm{Sm}, \mathrm{Eu}, \mathrm{Gd}$, and Tb. The elements Ce, Pr, Nd, Dy, and Ho were intermediate. Separation factors of $\alpha_{\mathrm{Lu} / \mathrm{La}} \sim 5, \alpha_{\mathrm{Lu} / \mathrm{Sm}}$ $\sim 28$, and $\alpha_{\mathrm{Lu} / \mathrm{Tb}} \sim 25$ were obtained in a single extraction, for extraction from $1 \mathrm{M} \mathrm{HNO}_{3}$. For separations from $8 \mathrm{M} \mathrm{HNO}_{3}, \alpha_{\mathrm{Lu} / \mathrm{La}} \sim 104, \alpha_{\mathrm{Lu} / \mathrm{Sm}} \sim 3.5$, and $\alpha_{\mathrm{Lu} / \mathrm{Tb}} \sim 1.8$ were obtained.

The distribution ratios for the lanthanides and Am were plotted versus their ionic radii for RTIL extractions from $1 \mathrm{M}$ and $6 \mathrm{M}$ acid and are shown in Fig. 7. For extractions from $1 \mathrm{M}$ acid, the extraction efficiency of the light lanthanides increased with decreasing ionic radius, as was found for extractions from 1-octanol, suggesting that TBDGA complexation of these metals once again depends upon increasing charge density along the lanthanide contraction. However, the highest distribution ratios were achieved for Eu, after which they decreased with decreasing radius for the remaining metals. A discontinuity is again evident at $\mathrm{Gd}$; however, Am has lower distribution ratios than would be predicted based on its radius. Yttrium follows the lanthanide trend only approximately.

Apparently another parameter influences the extraction efficiency of the heavy lanthanides into RTIL solution at low nitric acid concentration. The decreasing distribution

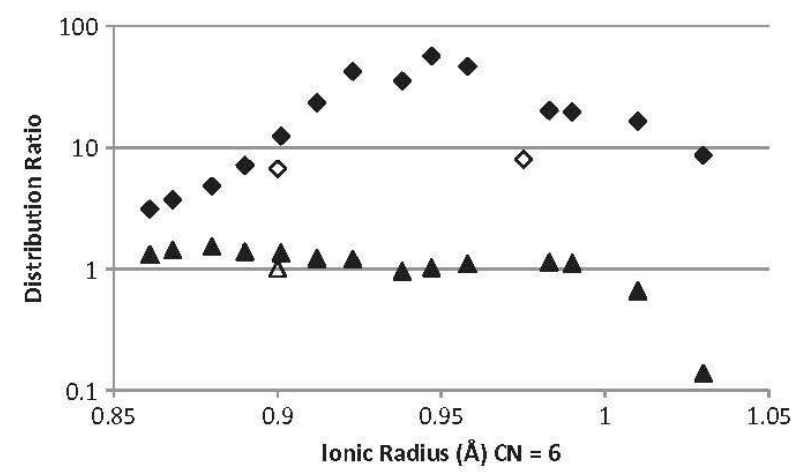

Figure 7 TBDGA RTIL extraction distribution ratios from $1 \mathrm{M} \mathrm{HNO}_{3}$ (diamonds) and $6 \mathrm{M} \mathrm{HNO}_{3}$ (triangles) as a function of ionic radius for extractions in $\left[\mathrm{C}_{4} \mathrm{MIM}\right]\left[\mathrm{Tf}_{2} \mathrm{~N}\right]$. The left open diamond is $\mathrm{Y}$, the right open diamond is Am. The open triangle is Y. Radii are those of [22]. 
ratios for the heavy lanthanides when extracted from $1 \mathrm{M} \mathrm{HNO}_{3}$ may result from decreasing nitrate formation constants. The reported nitrate formation constant values $\left(\beta_{1}\right)$ for the lanthanides vary widely in the literature, ${ }^{[33]}$ and we were unable to find a correlation between them and the distribution ratios measured here. However, a qualitative inspection of the data provided by Andersson et al. ${ }^{[33]}$ does indicate that the tendency toward nitrate formation decreases for the heavy lanthanides. This suggests that anionic nitrate species, rather than neutral complexes, are extracted at higher acidity. These lower $\beta$ values are apparently compensated for in the presence of very high nitrate concentrations ( $>6.0 \mathrm{M}$, as also shown in Fig. 7), where the extraction efficiency of the heavy lanthanides increased. The correlation between the distribution ratio and the ionic radius at $6 \mathrm{M} \mathrm{HNO}_{3}$ is more similar to that for the extractions from 1-octanol, indicating that the charge density of the metal ion is once again the main parameter influencing the extraction efficiency at higher nitric acid concentrations.

\section{Extractions from Simulated Nuclear Fuel Dissolution}

Octanol as a diluent is well-known in fuel cycle applications, and the RTILs have often been proposed as replacement diluents for the ligands used in nuclear fuel cycle solvent extraction processes. The extraction of radiotracer $\mathrm{Eu}, \mathrm{Am}$, and $\mathrm{Ce}$ from a nuclear fuel raffinate simulant solution using $0.007 \mathrm{M}$ TBDGA in $\left[\mathrm{C}_{4} \mathrm{MIM}\right]\left[\mathrm{Tf}_{2} \mathrm{~N}\right]$ is shown in Fig. 8 . The raffinate simulant solution contains the major lanthanide fission products and other constituents to be expected in the dissolved nuclear fuel that has undergone processing to remove $\mathrm{U}, \mathrm{Np}$, and $\mathrm{Pu}$. The simulant constituents and their concentrations are shown in Table 1.

It can be seen in Fig. 8 that the lanthanides and Am are extracted as expected based on the results of Figs. 5 and 6, but with decreased distribution ratios due to loading by the higher overall concentration of metals in the simulant. The $D_{\mathrm{Eu}}$, for example, at $1 \mathrm{M} \mathrm{HNO}_{3}$ was $\sim 18$ for the tracer solution, but only $\sim 0.03$ from the raffinate at the same acidity. The overall concentration of lanthanides in the simulant is about $10 \mathrm{mM}$ (Table 2), similar to that in the lanthanide tracer solution. However, the simulant also contains $3.71 \mathrm{mM} \mathrm{Zr}$, which is also well extracted by diamides. ${ }^{[8,10]}$ Thus, ligand concentrations $>0.007 \mathrm{M}$ would be

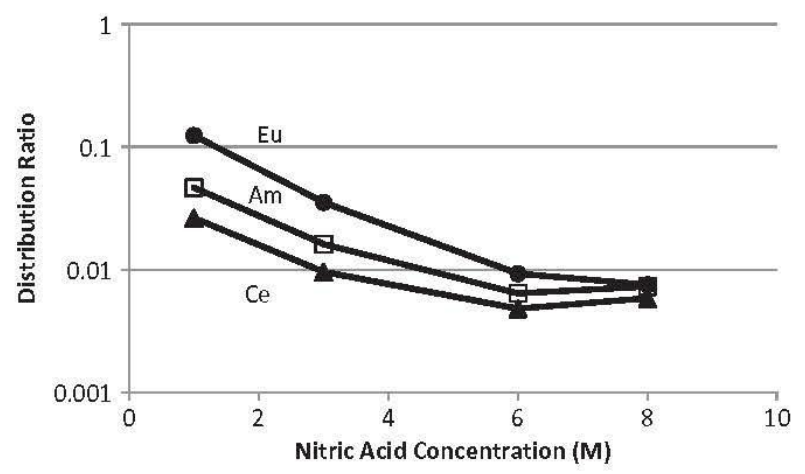

Figure 8 The RTIL extraction of Am (III), Ce (III), and Eu (III) radiotracers from acidic nuclear fuel raffinate simulant solution by $0.007 \mathrm{M}$ TBDGA in $\left[\mathrm{C}_{4} \mathrm{MIM}\right]\left[\mathrm{Tf}_{2} \mathrm{~N}\right]$. The distribution ratios are the mean values of duplicate extractions with an average error of $\pm 8 \%$. The average mass balance was $1.07 \pm 0.04$. 
Table 1 Raffinate simulant constituent concentrations (mM).

\begin{tabular}{lccc}
\hline Constituent & Concentration $(\mathrm{mM})$ & Constituent & Concentration $(\mathrm{mM})$ \\
\hline $\mathrm{Rb}$ & 0.45 & $\mathrm{La}$ & 1.18 \\
$\mathrm{Y}$ & 0.56 & $\mathrm{Ce}$ & 2.30 \\
$\mathrm{Zr}$ & 3.71 & $\mathrm{Nd}$ & 3.76 \\
$\mathrm{Cs}$ & 2.20 & $\mathrm{Sm}$ & 2.49 \\
$\mathrm{Ba}$ & 1.92 & $\mathrm{Eu}$ & 0.07 \\
$\mathrm{Gd}$ & 0.13 & & \\
\hline
\end{tabular}

required to achieve acceptable lanthanide distribution ratios. Additionally, additives such as oxalic acid have been used to mitigate $\mathrm{Zr}$ extraction. ${ }^{[8]}$ However, as can also be seen in Fig. 8, there is little opportunity to separate Am from the lanthanides using the RTIL diluent.

\section{CONCLUSIONS}

The solvent extraction behavior of the diglycolamide TBDGA was characterized in both the conventional molecular diluent 1-octanol, and in the RTIL $\left[\mathrm{C}_{4} \mathrm{MIM}\right]\left[\mathrm{Tf}_{2} \mathrm{~N}\right]$ for the lanthanides and for Am. Disparate solvent extraction profiles versus acid concentration were obtained for the two diluents, with high extraction efficiency for highly acidic conditions for 1-octanol and with low acidity favoring extraction in the RTIL. In both cases the nitrate complexes of the metals were extracted, except that neutral complexes were extracted into 1-octanol and ionic complexes extracted into the RTIL. These ionic complexes were either cations or anions depending on the nitrate concentration in the aqueous phase. It now seems well established that the mechanism of extraction into RTILs is often different than that in molecular solvents, and therefore solvent extraction characteristics need to be reevaluated even for well-known ligands when used in RTIL diluents.

The ligand TBDGA in $\left[\mathrm{C}_{4} \mathrm{MIM}\right]\left[\mathrm{Tf}_{2} \mathrm{~N}\right]$ did not provide separation factors adequate for Am/lanthanide partitioning; however, it would be useful as a group separation for the trivalent metals at lower nitric acid concentrations. For extractions into 1-octanol, a reasonable separation factor $\alpha_{\mathrm{Eu} / \mathrm{Am}}$ of 11 was obtained from $6 \mathrm{M} \mathrm{HNO}_{3}$, suggesting that these metals could be separated using the molecular diluent. The possibility of lanthanide intergroup separations appears to be feasible in both diluents with appropriate choice of aqueous phase acidities.

\section{ACKNOWLEDGMENTS}

This work was partially supported by DOE-NEUP grant (TO 00058), and the work was performed under DOE Idaho Operations Office Contract DE-AC07-05ID14517. The authors thank D. Peterman for helpful discussions.

\section{REFERENCES}

1. Nilsson, M.; Nash, K.L. Review article: A review of the development andoperational characteristics of the TALSPEAK process. Solvent Extr. Ion Exch. 2007, 25, 665-701.

2. Mincher, B.J.; Martin, L.R.; Schmitt, N.C. Tributylphosphate extraction behavior of bismuthateoxidized americium. Inorg. Chem. 2008, 47, 6984-6989. 
3. Thiollet, G.; Musikas, C. Synthesis and uses of the amides extractants. Solvent Extr. Ion Exch. $1989,7,813-827$.

4. Modolo, G.; Vijgen, H.; Serrano-Purroy, D.; Christiansen, B.; Malmbeck, R.; Sorel, C.; Baron, P. DIAMEX counter-current extraction process for recovery of trivalent actinides from simulated high active concentrate. Sep. Sci. Technol. 2007, 42, 439-452.

5. Paulenova, A.; Alyapyshev, M. Yu.; Babain, V. A.; Herbst, R. S.; Law, J. D. Extraction of lanthanides with diamides of dipicolinic acid from nitric acid solutions. I. Sep. Sci. Technol. 2008, 43, 2606-2618.

6. Sasaki, Y.; Dugo, Y.; Suzuki, S.; Tachimori, S. The novel extractants, diglycolamides, for the extraction of lanthanides and actinides in $\mathrm{HNO}_{3}-n$-dodecane system. Solvent Extr. Ion Exch. 2001, 19, 91-103.

7. Gujar, R.B.; Ansari, S.A,; Murali, M.S.; Mohapatra, P.K.; Manchanda V.K. Comparative evaluation of two substituted diglycolamide extractants for actinide partitioning. J. Radioanal. Nucl. Chem. 2010, 284, 377-385.

8. Modolo, G.; Asp, H.; Schreinemachers, C.; Vijgen, H. Development of a TODGA based process for partitioning of actinides from a PUREX raffinatepart 1: Batch extraction optimization studies and stability tests. Solvent Extr.Ion Exch. 2007, 25, 703-721.

9. Ansari, S.A.; Pathak, P.N.; Manchanda, V.K.; Husain, M.; Prasad, A.K.; Parmar, V.S. N,N, $\mathbf{N}^{\prime}, \mathrm{N}^{\prime}$ tetraoctyl diglycolamide (TODGA): A promising extractant for actinide-partitioning from HighLevel Waste (HLW). Solvent Extr. Ion Exch. 2005, 23, 463-479.

10. Horwitz, E.P.; McAlister, D.R.; Bond, A.H.; Barrans Jr., R.E. Novel extraction of chromatographic resins based on tetraalkyldiglycolamides: Characterization and potential applications. Solvent Extr. Ion Exch. 2005, 23, 319-344.

11. Mekki, S.; Wai, C.M.; Billard I.; Moutiers G.; Burt, J.; Yoon, B.; Wang, J.S.; Gaillard, C.; Ouadi, A.; Hesemann, P. Extraction of lanthanides from aqueous solution by using room-temperature ionic liquid and supercritical carbon dioxide in conjunction. Chem. Eur. J. 2006, 12, 1760-1766.

12. Dai, S.; Ju, Y.H.; Barnes, C.E. Solvent extraction of strontium nitrate by crown ether using roomtemperature ionic liquids. J. Chem. Soc. Dalton Trans. 1999, 1201-1202.

13. Jensen, M.P.; Neuefeind, J.; Beitz, J.V.; Skanthakumar, S.; Soderholm, L. Mechanisms of metal ion transfer into room-temperature ionic liquids: The role of anion exchange. J. Am. Chem. Soc. 2003, 125, 15466-15473.

14. Dietz, M.L.; Dzielawa, J.A. Ion-exchange as a mode of cation transfer into room-temperature ionic liquids containing crown ethers: Implications for 'greenness' of ionic liquids as diluents in liquid-liquid extraction. Chem. Commun. 2001,2124-2125.

15. Shimojo, K.; Kurahashi, K.; Naganawa, H. Extraction behavior of lanthanides using a diglycolamide derivative TODGA in ionic liquids. Dalton Trans. 2008, 5083-5088.

16. Bridges, N.J.; Visser, A.E.; Williamson, M.J.; Mickalonis, J.I.; Adams, T.M. Effects of gamma radiation on electrochemical properties of ionic liquids. Radiochim. Acta 2010, 98, 243-247.

17. Rout, A.; Karmakar, S.; Venkatesan, K.A.; Srinivasan, T.G.; Rao, P.R.V. Room temperature ionic liquid dluent for the mutual separation of europium(III) from americium(III). Sep. Pur. Technol. 2011, 81, 109-115.

18. Billard, I.; Ouadi, A.; Gaillard, C. Liquid-liquid extraction of actinides, lanthanides, and fission products by use of ionic liquids: From discovery to understanding. Anal. Bioanal. Chem. 2011, $400,1555-1566$.

19. Koh, M.; Yoo, J.; Park, Y.; Bae, D.; Park, K.; Kim, H.; Kim, H. Supercritical CO2 extraction of uranium(VI) from $\mathrm{HNO}_{3}$ solution using $N, N, N^{\prime}, N^{\prime}$-tetrabutyl-3-oxpentanediamide. Ind. Eng. Chem. Res. 2006, 45, 5308-5313.

20. Huddleston, J.G.; Visser, A.E.; Reichert, W.M.; Willauer, H.D.; Broker, G.A.; Rogers, R.D. Characterization and comparison of hydrophilic and hydrophobic room temperature ionic liquids incorporating the imidazolium ion. Green Chem. 2001, 3, 156-164.

21. Baker, J.D.; Mincher, B.J.; Meikrantz, D.H.; Berreth, J.R. Partitioning studies to separate actinides from ICPP HLW. Solvent Extr. Ion Exch. 1988, 6, 1049-1065. 
22. Shannon, R.D. Revised effective ionic radii and systematic studies of interatomic distances in halides and chalcogenides. Acta Cryst. 1976, A32, 751-767.

23. Visser, A.E.; Rogers, R.D. Room-temperature ionic liquids: new solvents for $f$-element separations and associated solution chemistry. J. Solid State Chem. 2003, 171, 109-113.

24. Nakashima, K.; Kubota, F.; Maruyama, T.; Goto, M. Ionic liquids as a novel solvent for lanthanide extraction. Anal. Sci. 2003, 19, 1097-1098.

25. Hofmeister, F. Zur Lehre von der Wirkung der Salze. Arch. Exp. Pathol. Pharmokol. 1888, 24, $247-260$.

26. Knoeck, J. Vibrational spectrometric and electrochemical evidence for lanthanum(III)-nitrate complexes in aqueous solution. Anal. Chem. 1969, 41, 2069-2071.

27. Oikawa, T.; Urabe, T.; Kawano, S.; Tanaka, M. Basic study of lanthanide nitrate species in solution by electrospray ionization mass spectrometry. J. Solution Chem. 2011, 40, 1094-1107.

28. Shen, Y.; Tan, X.; Wang, L.; Wu, W. Extraction of the uranyl ion from the aqueous phase into an ionic liquid by diglycolamide. Sep. Pur. Technol. 2011, 78, 298-302.

29. Rout, A.; Venkatesan, K.; Srinivasan, V.K.; Rao, P.R. V. Unusual extraction of plutonium(IV) from uranium(VI) and americium(III) using phosphonate based task specific ionic liquids. Radiochim. Acta 2010, 98, 459-466.

30. Cocalia, V.A.; Jensen, M.P.; Holbrey, J.D.; Spear, S.K.; Stepinski, D.C.; Rogers, R.D. Identical extraction behavior and coordination of trivalent or hexavalent f-element cations using ionic liquid and molecular solvents. J. Chem. Soc. Dalton Trans. 2005, 1966-1971.

31. Giridhar, P.; Venkatesan, K.A.; Srinivasan, T.G.; Vasudeva Rao, P.R. Extraction of uranium(VI) from nitric acid medium by 1.1 M tri-n-butylphosphate in ionic liquid diluent. J. Radioanal. Nucl. Chem. 2005, 265, 31-38.

32. Wang, J.S.; Sheaff, C.N.; Yoon, B.; Addleman, R.S.; Wai, C.M. Extraction of uranium from aqueous solutions by using ionic liquid and supercritical carbon dioxide in conjunction. Chem. Eur. J. 2009, 15, 4458-4463.

33. Andersson, S.; Eberhardt, K.; Ekberg, Ch.; Liljenzin, J.-O.; Nilsson, M.; Skarnemark, G. Determination of stability constants of lanthanide nitrate complex formation using a solvent extraction technique. Radiochim. Acta 2006, 94, 469-474. 